Portland State University

PDXScholar

Fall 11-5-2013

\title{
Martin Luther's "Two Kingdoms Theory": An Analysis through the Lens of Dietrich Bonhoeffer's Religionless Christianity
}

Janet Leigh Gesme

Portland State University

Follow this and additional works at: https://pdxscholar.library.pdx.edu/open_access_etds

Part of the Religion Commons

Let us know how access to this document benefits you.

\section{Recommended Citation}

Gesme, Janet Leigh, "Martin Luther's "Two Kingdoms Theory": An Analysis through the Lens of Dietrich Bonhoeffer's Religionless Christianity" (2013). Dissertations and Theses. Paper 1508.

https://doi.org/10.15760/etd.1512

This Thesis is brought to you for free and open access. It has been accepted for inclusion in Dissertations and Theses by an authorized administrator of PDXScholar. Please contact us if we can make this document more accessible: pdxscholar@pdx.edu. 
Martin Luther's "Two Kingdoms Theory”:

An Analysis through the Lens of Dietrich Bonhoeffer's Religionless Christianity

\author{
by \\ Janet Leigh Gesme
}

A thesis submitted in partial fulfillment of the requirements for the degree of

\author{
Master of Arts \\ in \\ World Language: German
}

Thesis Committee:

Steven Fuller, Chair

William Fischer

Kathleen A. Godfrey

Portland State University

2013 
(C) 2013 Janet Leigh Gesme 


\begin{abstract}
The following work is an analysis of Martin Luther's Two Kingdoms Theory. This influential and controversial theory was introduced in his 1523 treatise, Von weltlicher Obrigkeit-Secular Authority. Although this document was written almost 500 years ago and takes its cue from the writings of St. Augustine and the Bible, it continued to have a significant effect on German society in both the political and religious realm well into the present day. Based on an analysis of the text and on the culture and literature that led Luther to write Von weltlicher Obrigkeit, this thesis evaluates various interpretations and applications of the Two Kingdoms Theory. The specific effects of Luther's teaching during the Nazi era are examined politically and theologically. Dietrich Bonhoeffer's Religionsloses Christentum-Religionless Christianity and Martin Luther's Zwei-Reiche-Lehre-Two Kingdoms Theory will be compared to demonstrate that they illuminate the same truth from different vantage points: neither people nor their rules are viable substitutes for God. A brief introduction explains the means of analysis used in this thesis, which is based on Dietrich Bonhoeffer's call for a new religionless language as described in letters written during his imprisonment by the Nazi regime.
\end{abstract}




\section{Acknowledgements}

There is no doubt in my mind as to whom I should acknowledge first for the final product contained in these pages: I thank my God and Father, my Savior Jesus Christ, and the Holy Spirit for infinite patience and for not letting go of me throughout the research, writing, and revision stages of the thesis process. All of my other thanks pour out of this primary source: I am grateful for Larry Sewel, Adrienne Brown, my mother-Sara Lynch, Pastor Joel LiaBraaten, Stacey Donohue, Reid Kajikawa, and Dr. William Fischer for advice, revisions, proof-reading, and encouragement. Thank you!

To Pat Givens and Ruth Hoffman I owe a special debt of gratitude: your help in tracking down German and English versions of obscure literature was invaluable to me, along with your enthusiasm, proof reading, and advice. The great majority of what I learned came from the books that you tirelessly ordered for me. For help with the original German version of this thesis I thank Denise Krause, GiGi DeBerry, and Christoph Stauder. The countless hours you spent editing this work and advising me on matters of style, grammar, and quality will not be forgotten! Much of what you taught me I continue to use in each new paper I write. Thank you.

Thank you, Dr. Kathy Godfrey, for supporting me throughout 4 terms of graduate school and seeing me through to the end of my studies as a member of the thesis committee. 
My thanks to Dr. Steven Fuller are too deeply heart-felt to express on paper. The books you sent me in the mail, the encouragement, the excellent editing--I am more grateful than you can ever imagine. Without you, I would have thrown in the towel! But I must also thank my husband, Michael Gesme, who would not let me give up, no matter how frustrated I became. Thank you, Michael, for your unfailing love and support, and thank you to my son, Alex and my daughter, Zeta, for your patience during the thesis writing process.

In researching the topics of the Two Kingdoms Theory and Religionless Christianity a new world of fascinating, challenging literature has been opened up to me. And so I end my thanks where they began: thank you, my ever-present Lord, for this new world You have shown to me. I have learned much more than is written here in these pages, and I look forward to years of learning yet to come. 


\section{Table of Contents}

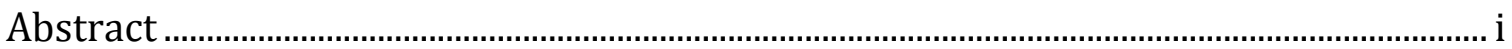

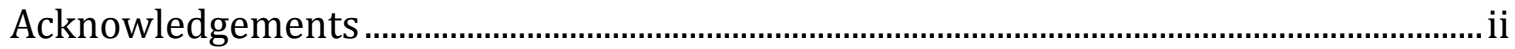

List of Diagrams ..............................................................................................................................vi

Preface

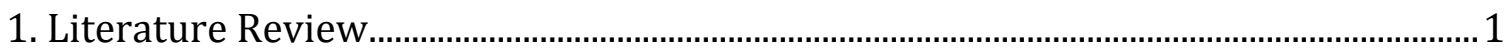

2. The Two Kingdoms Theory according to

Martin Luther's Treatise: Von weltlicher Obrigkeit..............................................................

3. The Traditions and Literature out of which

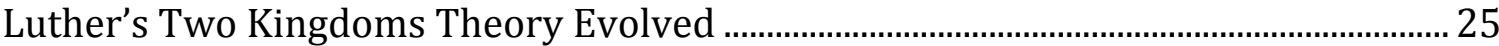

3.1: Religious Customs of the $16^{\text {th }}$ Century and Control of the People ..........................26

3.2: Augustine and his Influence on Martin Luther.............................................................. 33

3.3: The Influence of Holy Scriptures on Luther's Two Kingdoms Theory ................. 40

4. Luther's Two Kingdoms Theory during the time of National Socialism:

The Interpretations and Applications of Barth and Bonhoeffer ....................................... 46

4.1: Martin Luther: An anti-Semitic Hero? ..................................................................... 49

4.2: Martin Luther from Bonhoeffer's Point of View ...................................................... 53

4.3: The Weakness of the Two Kingdoms Theory:

Karl Barth's Criticism of the Evangelical Church ............................................................. 57

4.4: The Political Thought of Dietrich Bonhoeffer .............................................................. 65

5. Reinventing the Two Kingdoms Theory:

Bonhoeffer's Religionless Christianity …………………….............................................. 84

5.1: The Kingdom of God: Not a Synonym for Religion .................................................. 85

5.2: The Enlightenment of the World: Is Religion Still Necessary? .............................. 89

5.3: Violence in Religion.............................................................................................. 90

5.4: Defining Religion ......................................................................................................... 93

5.5: The "Diesseitigkeit" of the Kingdom of God........................................................... 97

5.6: The Kingdom of God is Religionless Christianity, which is Discipleship...........104

6. The Two Kingdoms Theory: A Visual Analysis ...............................................................107

Conclusion.................................................................................................................121

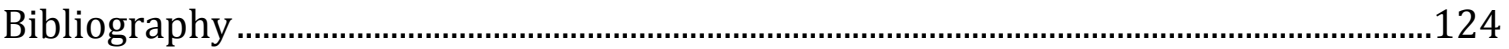


Appendix A: The Power of God.. 128

Appendix B: The Worth of a Counselor ………………………………………….....129

Appendix C: Primary Bible Verses used by Luther in Von weltlicher Obrigkeit.........130

Appendix D: Exceptions to the Rule ................................................................................131

Appendix E: The Command of the Old Testament to Love your Enemy ……………...132

Appendix F: The Sermon on the Mount............................................................................133

Appendix G: The Transfer of the Soul.................................................................................134 


\section{List of Diagrams}

Diagram 1: Two Spheres ...................................................................................................108

Diagram 2: God's Kingdom within the Kingdom of the World .........................................109

Diagram 3: The Kingdom of the World inside of God's Kingdom....................................109

Diagram 4: The Two Planes..................................................................................................110

Diagram 5: The Tangent and the Circle ........................................................................110

Diagram 6: The Separation that Connects.....................................................................111

Diagram 7: The Boundaries of the Kingdom of God, the Church, and the State.........111 


\section{Preface}

The primary goal of this thesis is to examine and present Martin Luther's (1483-1546) Zwei-Reiche-Lehre-Two Kingdoms Theory through the lens of Dietrich Bonhoeffer's (1906-1945) Religionsloses Christentum-Religionless Christianity. To understand this goal, one must first understand what Bonhoeffer meant by “Religionless Christianity." Bonhoeffer believed that institutional religion, as he knew it, was coming to its historical end, and that the world would soon enter a phase in which religion was no longer relevant. ${ }^{1}$ According to Bonhoeffer, in this new phase of history, Christ is "nicht mehr Gegenstand der Religion, sondern etwas ganz anderes, wirklich Herr der Welt." ${ }^{2}$ He insisted that Christ was a person whereas institutionalized religion was and is simply a collection of rituals. Bonhoeffer believed that Christ is the Son of God, whereas religion is merely a construct to assist in understanding that concept. He longed for people to have a connection with God that is strong enough to see through the hypocrisy of religion and to have the courage to live and act under the direct influence of Christ, regardless of what religious authorities might say.

\footnotetext{
${ }^{1}$ Bonhoeffer, Widerstand und Ergebung, 141. Bonhoeffer's definition of religion was „die zeitbedingten Voraussetzungen der Metaphysik, der Innerlichkeit, etc" 141. Luther's words that express the same concept are easier to understand: it is the attempt of worldly organizations, be it a secular or religious institution, to do the following: „die Menschen mit ihren Gesetzen und Geboten (zu) zwingen ..., so oder so zu glauben“. Luther, Von weltlicher Obrigkeit. 25.

2 Bonhoeffer, Widerstand und Ergebung, 141.
} 
According to Clifford Green, the Religionless Christianity proposed by Bonhoeffer is a "psychic posture,"3 meaning a specific mental approach to one's relationship to God and others. This particular posture accredits God alone with the right to judge the human soul. Although Bonhoeffer's Religionless Christianity demands a close relationship with Jesus, it does not assume that it has the ability to judge another's relationship with Christ. Because this thesis is written with Bonhoeffer's Religionless Christianity in mind, it will be presented from the point of view that assumes that neither religion nor membership in a particular church is necessary to have a relationship with Christ. The attempt to analyze interpretations of the Two Kingdoms Theory during the time of National Socialism in a religionless style will be carried out through the presupposition that God transcends all religions and cannot be contained by human theology.

In his treatise, Von weltlicher Obrigkeit, Luther refers to the Kingdom of God and the Kingdom of the World. According to his description, churches are a part of the Kingdom of the World rather than a part of the Kingdom of God. ${ }^{4}$ The Two Kingdoms Theory lends itself to exploration in a religionless fashion due to Luther's claim that religion, in the sense of the human effort to control the soul, will not be successful: "wie kann ein Mensch die Herzen sehen, erkennen, richten, beurteilen und ändern? Denn solches ist allein Gott vorbehalten." ${ }^{5}$ Just as Bonhoeffer separated the concept of God and religion, Luther separated the Kingdom of God from the church. By means of institutionalized religion and churches, people try to

3 Green, Bonhoeffer: A Theology of Sociality, 269.

${ }^{4}$ Luther, Von weltlicher Obrigkeit, 26, 29.

5 Ibid. 27. 
establish a connection with their creator. The desire to connect with one's Maker can be put into action in a positive manner, but when a person or group of people confuse their efforts with God himself, they begin to think that all people should do exactly the same things that they are doing. This leads to the tendency to judge others. According to Bonhoeffer, when one person judges another, he loses his connection with God and with his fellowman. ${ }^{6}$ Therefore it is of utmost importance that one does not confuse God with religion, because that is tantamount to confusing God with ourselves.

The goal of Bonhoeffer's Religionless Christianity is to discourage deified concepts of churches and religion and recognize that only God is God. Only then can a person dare to be religious or non-religious. But, until it is understood that churches are not God, people will continue to expect an impossible perfection from religion, churches, and religious people. Perfection cannot be found in the Kingdom of the World. Only the other kingdom, the Kingdom of God, offers perfect love, peace and freedom. God has an abundant supply of each of these, which humans are unable to offer or replicate. Religion and church membership are not prerequisites for having a relationship with God. The principle of the Two Kingdoms Theory, as well as that of Religionless Christianity, is supported by the words of the Apostle Paul in Acts:

The God who made the world and everything in it is the Lord of heaven and earth and does not live in temples built by hands. And he is not served by human hands, as if he needed anything, because he himself gives all men life and breath and everything else. From one man he made every nation of men, that they should inhabit the whole

${ }^{6}$ Bonhöffer, Ethics, 34 
earth; and he determined the times set for them and the exact places where they should live. God did this so that men would seek him and perhaps reach out for him and find him, though he is not far from each one of us. For in him we live and move and have our very being. ${ }^{7}$

In essence, Luther's Two Kingdoms Theory and Bonhoeffer's Religionless Christianity argue the same point by delineating the distinction between the capabilities of mankind and the power of God. However, the cultures in which they lived were very different. Neither Luther nor Bonhoeffer lived or wrote literature in a vacuum. Their theories were presented in dialog with other political and religious thinkers of their times. Their reactions to the issues presented by the cultures in which they lived will be examined through their presentations of the Two Kingdoms Theory and its practical applications. The pure simplicity of the premise that God is God and man is man will be juxtaposed with the overwhelming complexity of politics, church and state, and opinions concerning spiritual matters as understood by Luther, Bonhoeffer, their mentors, and their adversaries.

\footnotetext{
${ }^{7}$ Acts 17:24-28a.
} 


\section{Literature Review}

Luther's Two Kingdoms Theory has had widespread and varying effects. It is a theme that is discussed not just in Lutheran churches, but in diverse theological circles. In his book, Zwei Schwerter Zwei Reiche, Volker Mantey claims that there is hardly any other theological teaching from Martin Luther that has been argued in such a controversial fashion in $20^{\text {th }}$ century literature. ${ }^{8}$ Luther commented on his own theory saying: "I may boast here, that since the time of the Apostles the temporal sword and government have never been so clearly described or so highly valued as by me."9 In contrast, David M. Whitford, in his article Cura Religionis or the Two Kingdoms: The Late Luther on Religion and the State in the Lectures on Genesis, comments that "the source of Luther's major shortcoming (is) his theology of the Two Kingdoms." Whitford cites Thomas Müntzer, who believed that Luther enabled secular authorities to practice authoritarian subjugation, and in the same paragraph he mentions Peter Frarin, who in 1566 complained that the protestant followers of Luther advocated rebellion and the subversion of civil order. ${ }^{10}$

Did Luther enable unbridled power in the government or did he undermine it? Numerous and diverse interpretations have come from this theory that Luther deemed "clear" and "classic."11 Theologians and politicians often discuss the Two Kingdoms Theory in association with the separation of church and state; some argue

8 Mantey, Zwei Schwerter Zwei Reiche, 1.

${ }^{9}$ Quote from English source. Thompson, The Political Thought of Martin Luther, 1.

10 Whitford, Cura Religionis or Two Kingdoms: The Late Luther on Religion and the State in the Lectures on Genesis, 41.

11 Thompson, The Political Thought of Martin Luther, 1-2. 
that Luther was a forerunner, advocating the separation of church and state; others claim that he in no way recommended separating these two organizations. ${ }^{12}$ Although the Two Kingdoms Theory often initiates conversation about the relationship of the church and state, it is not limited to that topic. This teaching is also brought into play when discussing abortion, ${ }^{13}$ mujerismo, ${ }^{14}$ and war ethics. ${ }^{15}$ Its influence is evident in the academic world and the governments of Norway, South Africa, Scotland, the United States, and China as well as in Germany. ${ }^{16}$ Although Luther was directly addressing the authorities, the church and the people of his time, his teachings found in Von weltlicher Obrigkeit-Secular Authority have been continually implemented, although the applications are often contradictory.

The ability to interpret and implement this theory in diverse and creative ways is in part due to the lack of clarity found in Von weltlicher Obrigkeit. What are the two kingdoms? Are they spiritual and worldly, eternal and temporal, church and state, or good and evil? Many perspectives can be argued and supported using the treatise, Von weltlicher Obrigkeit. The theory is most commonly used to determine

\footnotetext{
12 Heldberg, Martin Luther - Vater der Reformation, Vordenker der Trennung von Staat und Kirche, 16; Hamburger, Separation of Church and State, 22; Jodock, "Lutherans and politics," 22.

${ }^{13}$ http://steadfastlutherans.org/?p=26260. As of May 3, 2013.

14 Vargas, "Mujerismo and The Two Kin-doms: Distinction and Reconciliation," 231. Mujerismo is the involvement of Latin-American women in society and politics, especially in regards to social justice.

15 Neuss, "Luthers Stellungnahme zu den Kriegsfällen seiner Zeit."

16 Glenthoj et al., Die Öffentliche Verantwortung der Evangelisch-lutherischen Kirche in einer Bekenntnissituation; Monyai, "The significance of Luther's two kingdoms theory to the South African situation"; MacDonald, "Ecclesiastical Representation in Parliament in PostReformation Scotland"; Ji, "Two-Kingdoms Theory-Framework of Lutheran Theories of Law, Politics, and Society."
} 
the separate roles of the church and the state, and to establish the relationship between the two.

Rather than arguing if Luther was, in fact, recommending the separation of church and state, this thesis will present both sides of the teaching, including elements of separation and elements of overlap and cooperation. This thesis examines and compares the contrasting interpretations of the Two Kingdoms Theory during the time of National Socialism in Germany and analyzes the similarities between Dietrich Bonhoeffer's Religionless Christianity and Luther's theory. The political ideas found in Bonhoeffer's works from 1932 and 1933 as well the documents he wrote during his imprisonment by the Nazis (1943-1945) sometimes agree with Luther's Two Kingdoms Theory and at other times refute its validity. The core of Bonhoeffer's Religionless Christianity, however, supports Luther's theory concerning the Kingdom of God. They both address the same issue: mankind's tendency to confuse themselves with God or to deify things, circumstances, and feelings.

The primary literature of this thesis is Martin Luther's Von weltlicher Obrigkeit and Bonhoeffer's Berlin: 1932-1933, as well as Widerstand und Ergebung: Briefe und Aufzeichnungen aus der Haft. The thesis explores the works of Luther and Bonhoeffer in light of the figures who influenced them the most. Luther's primary influences were Jesus, the Apostles of Jesus, and Augustine of Hippo. Luther claimed that since the writing of the New Testament only Augustine had described the 
kingdoms in a satisfactory manner. ${ }^{17}$ Luther's Von weltlicher Obrigkeit was heavily influenced by Saint Augustine's The City of God. This thesis uses O'Donnells Augustine: A New Biography to illuminate Augustine's background, comparing the legendary Bishop of Hippo's motives and style of writing with that of Luther.

Because the culture of his times played an important role in the development of the Two Kingdoms Theory, the political, cultural and historical circumstances in which Martin Luther lived and worked will be explored with the help of the literature of Bainton, Spitz, Karant-Nunn, and Thompson. ${ }^{18}$

Just as Luther was influenced by the literature of Saint Augustine, Bonhoeffer was heavily influenced by both the works and person of Karl Barth. Unlike Luther and Augustine, whose lifetimes were separated by 1100 years, Barth and Bonhoeffer were contemporaries. Bonhoeffer, who was 20 years younger than Barth, was able not only to learn from his written works, but also had the opportunity to spend time with Barth and ask him for advice concerning the church politics of the 1930s. Karl Barth, who did not want to continue teaching the dogma of the evangelical church, wrote the books Römerbrief-The Epistle to the Romans and Rechtfertigung und Recht-Church and State in order to refute in part Luther's theory, which he first dubbed the "Two Kingdom Theory."19 This thesis uses these

\footnotetext{
17 Thompson, The Political Thought of Martin Luther 1.

18 Thompson, The Political Thought of Martin Luther; Spitz, The Protestant Reformation: 1517-1559; Karant-Nunn, Reformation of Ritual; Bainton, The Reformation of the Sixteenth Century.

19 Bernhard, Luthers Theologie in Ihrer Historischen Entwicklung und in Ihrem systematischen Zusammenhang, 172.
} 
two books along with Barth's personal correspondence with Bonhoeffer to better understand his influence in the thought and actions of the younger theologian.

Reading the works of Karl Barth is not an easy task. His Kirchliche Dogmatik alone consists of twelve volumes-more than seven thousand pages—and that does not take into account the hundreds of other books, articles, and letters that he wrote. ${ }^{20}$ However, it is not merely the number of works that he wrote that poses a challenge to the reader, but the style in which he expressed himself. ${ }^{21}$ Many Bible scholars consider Barth to be the most important theologian of the past five hundred years. His book, Römerbrief, is described by Metaxas as a "smart bomb" that fell on "the ivory tower of scholars" in the early $20^{\text {th }}$ century. ${ }^{22}$ When reading Barth's works, one cannot deny the genius of the author. A background knowledge concerning almost every theologian and philosopher that lived before Barth is necessary in order to even begin to comprehend his theories, not to mention a working knowledge of mathematics and church politics of the $20^{\text {th }}$ century. ${ }^{23}$ The

\footnotetext{
${ }^{20}$ Barth, How I Changed my Mind. 12.

${ }^{21}$ Wikipedia includes the following unsubstantiated quote from Barth that reads: "I haven't even read everything I wrote." This was presumably his response to a proud student claiming that he had read everything written by Barth. http://en.wikipedia.org/wiki/Karl_Barth: As of March 1, 2013.

22 Metaxas, Bonhoeffer: Pastor, Martyr, Prophet, Spy. 60.

${ }^{23}$ In order to understand the references to philosophers and philosophies that Barth weaves into his literature, the following books were used:
}

1. Historical Introduction to Philosophy by Albert B. Hakim. This book clarifies the ideas of Hegel (1770-1831), which would later be referred to using the terms thesis, antithesis, and synthesis. Hegel's goal was to overcome and resolve contradictions (476). His thoughts about the interaction between the thesis (affirmation) and the antithesis (negation) are described as "the dialectic" or the "dialectic process". Karl Barth's theories received their label out of this line of philosophical thought: "dialectic theology."

2. Philosophies of Life by W. S. Sahakian. This book was used to gain insight concerning Barth's favorite philosopher, Soren Kierkegaard (1813-1855). One 
book, How I Changed my Mind, by Karl Barth and John D. Godsey depicts how Barth dealt with the politics of his day. Above all, one must have a solid knowledge of the Bible in order to read Barth effectively. His books are not entertaining nor light reading, but they offer deep, complex commentary on religion, politics and philosophy.

Although Barth did not admire many of Martin Luther's works, he had great respect for the writings of the reformer John Calvin. A collection of reformation literature edited by Lewis W. Spitz entitled The Protestant Reformation offers a rare insight into the character of the shy John Calvin through a letter that he wrote in 1557. In it we see that Calvin, who held theological ideas very similar to those of his predecessor Martin Luther, was a modest, humble man in contrast to the rough, often angry character of Luther. This book from Spitz also offers insight concerning Zwingli, another reformer often referred to by Barth.

Although Bonhoeffer drew his ideas concerning Religionless Christianity from Karl Barth, ${ }^{24}$ it is Bonhoeffer's name that has come to be associated with this concept. A Theology of Life: Dietrich Bonhoeffer's Religionless Christianity by Ralf K. Wuestenberg helps trace the origins of Bonhoeffer's ideas concerning the conceptual separation of religion and Christianity, pointing out the influential role

example of Kierkegaard's way of thinking can be seen in this quote: "Dependence on God is the only independence, because God does not weigh you down. Only what is earthly and especially earthly wealth weighs you down. He who is completely dependent on God has a lightness in his heart."

3. The Fundamental Principles of the Metaphysic of Ethics by Immanuel Kant, translation by Otto Manthey-Zorn.

${ }^{24}$ Barth, in addition to distinguishing God from religion, claimed that Jesus has simply nothing to do with religion. Wüstenberg, A Theology of Life. 31, 54. 
played by Karl Barth in Bonhoeffer's academic development. This thesis also addresses Bonhoeffer's involvement with the German resistance with the help of Peter Hoffmann's Behind Valkyrie: German Resistance to Hitler: Documents and Eric Metaxas's best seller, Bonhoeffer: Pastor, Martyr, Prophet, Spy. Other than the biography by Eberhardt Bethge, Bonhoeffer's best friend, Dietrich Bonhoeffer: Theologe-Christ-Zeitgenosse, Metaxas's book is the best-known biography of Bonhoeffer. It reads like a novel, though it is a thoroughly researched and academically strong piece of literature.

The most important book used in the preparation of this paper cannot be easily or simply labeled as primary, secondary or background literature. If one wants to understand the works of Luther, Bonhoeffer, or the literature of their predecessors, Augustine and Barth, one must have a Bible on hand. All four of these men considered the Bible to be the ultimate written authority and refer continually to the Old and New Testaments. ${ }^{25}$ It is their basic assumption that the Bible offers a basis for all reasonable thought. According to them, all worldly authorities, whether they know it or not, are under God's authority and as his written word, and the believer should give the Bible the highest place among all literature. In order to understand Luther's, Barth's and Bonhoeffer's arguments, I used a 1984 updated version of Luther's translation of the Bible, published by the Evangelical Church of Germany as well as the website biblegateway.com.

25 Augustine, The City of God, Book XV, Ch. 1; Bainton, The Reformation of the Sixteenth Century, 45; Bonhoeffer, Berlin 1932-1933, 375. 
This thesis will argue that that Martin Luther's Two Kingdoms Theory and Bonhoeffer's call for Religionless Christianity are similar: they represent one man's effort to remind the people of their time that neither the church nor the state is the almighty God. Both teachings categorize the state as well as the church as worldly organizations and place them in the realm of the Kingdom of the World. Luther and Bonhoeffer both claim that this realm is controlled, in part, by human beings, sometimes for the good of humanity and sometimes to the detriment of humanity. Luther, Augustine, Barth and Bonhoeffer wrote at length concerning the relationship that the church and state should have. This thesis will examine their theories and the diversity of the issues of their times will be compared with the similarity of the solutions that all four men proposed. 


\section{The Two Kingdoms Theory according to Martin Luther's Treatise: Von weltlicher Obrigkeit}

The formidable label of the "Two Kingdoms Theory" refers to the political ideas presented by Martin Luther primarily in his treatise Von weltlicher Obrigkeit. ${ }^{26}$ Although this theory may sound complicated, at its core it represents one of the simplest concepts known to mankind: the concept of heaven and earth. The basic idea is familiar to most people-there are two kingdoms, one of them is heaven and the other is earth. In heaven everything is perfect. There one finds perfect peace and love and no one suffers from sickness or poverty. On earth, however, there are many problems. On earth mankind searches for perfect peace and love, but it is hard to find. People suffer under many maladies: sickness, crime, unfulfilled longings, fear and death. Although defining and delineating between these two kingdoms seems quite simple on the surface, the complexities become evident when one tries to explain the effect of the two realms on the human experience. Martin Luther's treatise about this subject is still hotly debated, almost 500 years after he wrote it. What seems to be a simple concept, God's Kingdom and the Kingdom of the World, turns out to be a type of Pandora's box, which continues to instigate arguments about religion, politics, and the interaction of God with mankind.

In Von weltlicher Obrigkeit Luther juxtaposes the concepts of the Kingdom of God and the Kingdom of the World. He believed that the two kingdoms are characterized by a clear division of authority: the Kingdom of God is a realm in

26 Thompson, The Political Thought of Martin Luther, 37 
which God alone exercises authority, whereas God delegates authority to mankind in the Kingdom of the World. In spite of the clarity of the division of power, Luther's explanation of where these realms are to be found and what characterizes the two kingdoms is challenging to define. The clarity of the division of power is useless if one does not understand what the Kingdom of God is when compared to the Kingdom of the World. According to Luther, it is important to understand the construct of the separate kingdoms and how they interact in order to identify which authority figure is valid in which realm.

The differences that Luther ascribed to the two kingdoms are clear. Christ, God the Father, and the Holy Spirit rule in the Kingdom of God, which is described as being not "of the world."27 Although the Kingdom of God is not of the world, it is located, in part, in this world. ${ }^{28}$ In the Kingdom of God, there is no use of law or punishment because all people love each other with their whole heart and do what is best for each other. God rules over the hearts and souls of all and, therefore, they gladly imitate Jesus Christ through a life of selfless service to others. ${ }^{29}$ The only weapons necessary to fight falsehood and evil in this kingdom are the truth and the "Word of God." 30 In the Kingdom of God every one is equal. There are neither sects nor visible differences among people ${ }^{31}$ and no one is superior, for Christ alone

27 Luther, Selections from his Writings, Secular Authority, 368; John 18:36

28 Luther, Selections from his Writings, Secular Authority, 368; Matthew 6:33

${ }^{29}$ Luther, Selections from his Writings, Secular Authority, 384.

30 Ibid. 390.

31 Ibid. 368. 
rules. ${ }^{32}$ Every one is subject to each other and considers each other as better than themselves. ${ }^{33}$

In contrast, the Kingdom of the World necessitates laws and punishments in order to maintain peace. The people of this world rule over external things, such as the physical life and property of a person, however, no one can control the heart and soul of another person. Princes and lords ruled the Kingdom of the World in Luther's time, along with the Pope and bishops. Luther claimed that all governing agencies that rule over any "große Menge"34 represent the Kingdom of the World. This means that even the world's churches are a part of the earthly kingdom. According to Luther, God gave these systems-state governments, churches, and other ruling authorities - to mankind in order to maintain stability and/or to punish criminals. The powers of this world should not prevent people from doing good, but they should prohibit those who want to do evil from doing so. ${ }^{35}$

Luther's summary of these concepts states:

Deshalb hat Gott die zwei Regimente verordnet: das Geistliche, welches durch den Heiligen Geist Christen und rechtschaffene Leute macht, unter Christus, und das Weltliche, welches den Unchristen und Bösen wehrt, dass sie gegen ihren Willen äußerlich Frieden halten und still sein müssen. ${ }^{36}$

Luther does not only claim that these two kingdoms should be sharply distinguished, but that "wir müssen alle Menschen in zwei Teile teilen: die ersten

${ }^{32}$ Luther, Selections from his Writings, Secular Authority, 392.

${ }^{33}$ Luther, Von weltlicher Obrigkeit, 12.

34 Ibid. 12.

35 Luther, Selections from his Writings, Secular Authority, 387.

36 Luther, Von weltlicher Obrigkeit, 11. 
zum Reich Gottes, die andern zum Reich der Welt."37 Luther claims that humans should divide mankind into two groups: one group of pious people, who belong to the Kingdom of God, and another group of worldly people who are restricted to the Kingdom of the World. A closer reading of the treatise reveals that, according to Luther, the spiritual kingdom must remain empty because no pious or righteous people exist: "Nun aber kein Mensch von Natur Christ oder fromm ist, sondern sie allzumal Sünder und Böse sind, wehret ihnen Gott allen durchs Gesetz." ${ }^{38}$

Drawing from the information above, the conclusion is that all of mankind is under the rule of the earthly kingdom and that no one belongs in God's kingdom. Luther's treatise continually addresses "Christians," and yet claims that no one can be Christian and that all are sinners. The Kingdom of God, however, is not a static entity. It is an active process that "makes" Christians with the help of the Holy Spirit. ${ }^{39}$ Luther acknowledged that the population of this world is far from perfect, and yet there are still people who are willing to listen to God's voice and search for his will. Luther took on the challenge of defining the Kingdom of God because he believed that there are people who strive to live according to the rules of that realm. When exploring the structure of the heavenly realm, Luther emphasized the scarcity of laws, and mentioned only two rules: love and forgiveness. "Deshalb hat auch Christus kein Schwert geführt, hat auch in seinem Reich keines eingesetzt. Denn er

${ }^{37}$ Luther, Von weltlicher Obrigkeit, 9.

38 Ibid. 10.

${ }^{39}$ Luther, Selections from his Writings, Secular Authority, 370. 
ist ein König über Christen und regiert ohne Gesetz allein durch seinen heiligen Geist." 40

Luther paints an attractive picture of the Kingdom of God, but gives his reader the impression that entry into this kingdom is restricted, and that one needs to meet certain qualifications to gain access to the heavenly realm. Luther opens his treatise, Von weltlicher Obrigkeit, with advice on how to begin the process of entering the Kingdom of God. One must have enough faith in God to follow the advice of Jesus: "Thou shalt not resist evil, but agree with thine adversary; and if any man take away thy coat, let him have thy cloak also."41 With this commandment, Jesus asks His followers to resist defending themselves when they are attacked. Jesus taught people to pray: "Forgive us our sins, as we forgive those who sin against us." ${ }^{42}$ He teaches that one should expect forgiveness from God in proportion to one's willingness to forgive others. The ability to forgive others comes as a result of an understanding of God's willingness to forgive the sins of mankind. Luther indicated that when one believes in God, they are in possession of something invaluable: "Denn ihr habt das Himmelreich. Deshalb sollt ihr das Erdreich dem lassen, der es euch nimmt." 43 Luther assumed that the worth of the kingdom of heaven is much greater that the worth of the things of this world and, that through faith, one can gain the ability not to defend one's self, but to forgive others completely for any attacks made on one's person or belongings. Luther does not

40 Luther, Von weltlicher Obrigkeit, 13.

${ }^{41}$ Luther, Selections from his Writings, Secular Authority, 364; Matthew 5:39.

42 Matthew 6:12.

${ }^{43}$ Luther, Von Weltlicher Obrigkeit, 21. 
depict this idealistic goal as if it has already been achieved by all people who call themselves Christians, but argues that the Holy Spirit is continually engaged in the process of developing this sense of security and selflessness in Christ's followers. ${ }^{44}$

Luther wrote concerning the coexistence of these two kingdoms on this earth in this treatise. His writings contain little about what will happen after death and much about how the spheres should comingle here and now, but place special emphasis on the fact that they should remain separate. Luther believed that the two kingdoms should work together in order to make earthly organizations successful, whether the organization is secular or religious. Therefore he wrote concerning the two realms: "Keines ist ohne das Andere genug in der Welt." 45 In order to understand how the spheres support each other one must first understand how they are different and to what extent they should remain separate.

Luther argued vehemently that the two spheres should be sharply distinguished, demanding a conceptual separation of the two kingdoms. ${ }^{46}$ In order to do so one must understand that, according to Luther, in the Kingdom of God, God is the sole ruler. Too often humans confuse God's kingdom with the church. Indeed churches have the job of teaching about the Kingdom of God, but this in no way means that the church is the embodiment of heaven. The churches of this world have, unfortunately, just as many problems as any other organization. Many people

\footnotetext{
44 The word "things" in this sense includes a person's body and reputation.

45 Luther, Von weltlicher Obrigkeit, 12.

46 Ibid. 12: "Diesen muß man sagen; ja freilich ists wahr, daß Christen um ihrer selbst willen keinem Recht noch Schwert Untertan sind, noch seiner bedürfen; aber siehe zu und mach die Welt zuvor voll rechter Christen, ehe du sie christlich und evangelisch regierts. Das wirst du aber nimmermehr tun, den die Welt und die Menge sind und bleiben Unchristen ... Deshalb muß man diese beiden Regimente mit Fleiß voneinander scheiden."
} 
try to cover and conceal their wrong doings with the help of the church. The church is an earthly organization and is not interchangeable with God's kingdom. The Kingdom of God on earth consists of the hearts and souls of people who listen to their consciences and are willing to follow the will of God, not the structure of an organization. All organizations belong to the Kingdom of the World, churches included. Luther did not want anyone to compel him or anyone else "mit dem Papst zu halten, so oder so zu glauben," nor was he not afraid of the Pope's threats. ${ }^{47}$ The Pope and the institutional church can make mistakes and become corrupted, just as any other individual or group of people. For this reason, Luther emphasized in Von weltlicher Obrigkeit: "Man muss Gott mehr gehorchen als den Menschen." ${ }^{48}$

Another area where the two kingdoms should remain separate, according to Luther, is in the government. A country or governing body must not believe that it can be ruled only with the laws, or the lack thereof, that pertain to the heavenly kingdom. Referring to the bad side of human nature Luther says: "Deshalb ists in der Welt nicht möglich, dass ein christliches Regiment sich über alle Welt erstrecke, ja, nicht einmal über ein Land oder eine große Menge." ${ }^{49}$ The validity of this claim is obvious concerning governments. If parliament decided not to have any laws because all the citizens of the country called themselves "Christians" and every one would help each other out because of unfettered love for each another, the result would be a catastrophe. People need earthly rules and regulations. It would be a foolish fantasy to believe that we would willingly donate money for roads and

47 Luther, Von weltlicher Obrigkeit, 30, 7.

48 Ibid. 30; Acts 5:29.

${ }^{49}$ Luther, Von weltlicher Obrigkeit, 12. 
infrastructure and that no one would cheat anyone else. The task of the government is to establish societal order. Various religions also have such laws, because they also belong to the Kingdom of the World. ${ }^{50}$ Earthly laws are necessary because it cannot be assumed that people will always make the right decision without the help of an established system.

The final area in which the two kingdoms are not to be intermingled, according to Luther, is in the heart and soul of a person. "Der Seele soll und kann niemand gebieten, er wisse ihr denn den Weg gen Himmel zu weisen. Das kann aber kein Mensch tun, sondern Gott allein." ${ }^{51}$ Although it is impossible for a human to lead the soul of another to heaven or to hell, there are many people in every age who claim to have this power. "Nun kann sich jedenfalls menschliche Ordnung nicht in den Himmel hinein und über die Seele erstrecken." 52 Although this sentence expresses a simple, obvious truth that should not be contradicted, many churches and governments try to do just that: "extend its authority to heaven and over souls." God, however, who alone rules over the soul, has decided to share this power with only one other person: the owner of the soul. ${ }^{53}$ His message, given through his son

\footnotetext{
${ }^{50}$ Luther, Von weltlicher Obrigkeit, 21: "Mose (hat) solch Gesetz deshalb über die Bösen, die nicht zu Gottes Reich gehören, gegeben, damit sie sich nicht selbst rächen oder Ärgeres tun, sondern durch solch äußerliches Recht gezwungen werden, Böses zu unterlassen." The Law was given to the Hebrews because people within this religion needed and need guidelines, as do all groups of people.

${ }^{51}$ Luther, Von weltlicher Obrigkeit, 26.

52 Ibid. 29.

${ }^{53}$ Luther, Selections from his Writings, Secular Authority, 384-385.
} 
Jesus, is clear. He wants everyone to be saved. ${ }^{54}$ For Luther, this Biblical fact was a great relief, chasing the fear out of living and dying.

Unfortunately, there are still many problems in the earthly world that continue to afflict people. Perhaps Luther himself gave us one of the greatest fears, which is the idea that we should judge the souls of other people. Luther wrote: "Hier müssen wir Adams Kinder und alle Menschen in zwei Teile teilen: die ersten zum Reich Gottes, die andern zum Reich der Welt."55 Luther's suggestion is nonBiblical in nature. Jesus' command not to judge was reinforced through the claim that God alone can judge souls with Jesus as a mediator. ${ }^{56}$ Right before Luther wrote that we must divide all the children of Adam into two classes, he explained that to be perfect produces no outward differences..$^{57}$ Simply stated, this means that human beings cannot see into each other's hearts to know if they are living in obedience or rebellion to God. In addition, Luther makes the claim that some people who lived before the birth of Christ can be called Christians. ${ }^{58}$ Luther asserts that not only are there no outward signs to prove whether or not someone is a Christian, but a person can be "Christian" without ever having heard the name of Jesus Christ during his or her earthly life. Luther asserts that only God has authority over the

\footnotetext{
54 John 3:17.

55 Luther, Von weltlicher Obrigkeit, 9.

56 Matthew 7:1, John 3:5.

${ }^{57}$ Luther, Selections from his Writings, 368.

58 Luther, Von weltlicher Obrigkeit, 16: "Wenn aber jemand einwenden wollte, das Alte Testament sei aufgehoben und gelte nicht mehr ... das ist nicht so. Denn ... sie haben alle ebendenselben Geist und Glauben an Christus gehabt, den wir haben, und sind ebensowohl Christen gewesen wie wir."
} 
soul. ${ }^{59}$ What authority could be greater than that of deciding if a soul will go to heaven or hell? Under no circumstance should a Christian divide people into "two classes" as Luther suggests.

The Biblical challenge that stands before a Christian is not one of separating people into "two classes,"60 but rather to separate his or her own words and actions into two categories. One should know if what he or she is doing and saying fits in with the Kingdom of God or the Kingdom of this World. John the Baptist used the metaphor of wheat and chaff to describe the good and evil that Jesus will separate on the last day. ${ }^{61}$ Kernels of wheat and chaff, what is useable and what is not, are parts of the same plant. This suggests that all people have both good and bad inside of them and must be ready to separate these two elements, keeping the good and allowing the bad to be burned away. This last area in which the kingdoms should not be confused, the heart and soul of a person, is the most difficult area to understand and explore.

At the beginning of the Von weltlicher Obrigkeit, Luther explains: "Again, necessity is laid upon me ... to write concerning the secular authorities and the sword they bear; how it should be used in a Christian manner."62 With this statement Luther introduces the first area in which the kingdoms should overlap: in the person occupying a position of authority. He does not wish for a government to be led without the influence of godly wisdom, although he knows that this is often

${ }^{59}$ Luther, Selections from his Writings, Secular Authority, 386.

60 Ibid. 368.

61 Matthew 3:11-12.

62 Luther, Selections from his Writings, Secular Authority, 363 
the case. ${ }^{63}$ In Luther's opinion, a government should rule in a "Christian manner," and one-third of this treatise is dedicated to giving advice as to how a prince can accomplish this objective. That does not mean that earthly governments should give religious training-quite the opposite. ${ }^{64}$ But when a person with political power has a good relationship with God, the people under his authority will benefit from the fact that God is influencing the governing decisions that are being made. ${ }^{65}$ Luther's advice to the authorities is that they should: "nicht so denken: Land und Leute sind mein, ich wills machen, wie mirs gefällt, sondern so: Ich bin des Landes und der Leute, ich solls machen, wie es ihnen nützlich und gut ist."'66 In this way, the leader is to put the interests of the people before his or her personal comforts.

Luther summarized his advice to earthly authorities with the following four responsibilities: first, they should pray to God and have confidence in Him; second, they must love and serve the people; third, they should have an open but analytical mind towards the counsel given them; and finally, they should be strict on crime. ${ }^{67}$ Luther believed that the first duty of a prince, that of having confidence in God and spending time in prayer, would give him the strength and desire to lead in a selfless manner. Although human beings are selfish creatures by nature, the presence of God, ruling one's heart, can change this self-centered nature into the desire to serve

\footnotetext{
${ }^{63}$ Luther, Selections from his Writings, Secular Authority, 389.

${ }^{64}$ Ibid. 386

65 Ibid. 399.

66 Luther, Von weltlicher Obrigkeit, 38.

67 Ibid. 44: ". . . dass ein Fürst sich in vier Richtungen wenden soll: aufs erste: zu Gott mit rechtem Vertrauen und herzlichem Gebet, aufs zweite: gegen seine Untertanen mit Liebe und christlichem Dienst, aufs dritte: gegen seine Räte und Gewalten mit freier Vernunft und unbefangenem Verstand, aufs vierte: gegen die Übeltäter mit bescheidenem Ernst und Strenge."
} 
others. The servant leadership style described by Luther was based on the example set by Christ Jesus: "For even the Son of Man did not come to be served, but to serve, and to give his life as a ransom for many."68 Luther claims that the Kingdom of God is of more worth than anything that one can find in this world. "Denn ihr habt das Himmelreich. Deshalb sollt ihr das Erdreich dem lassen, der es euch nimmt." ${ }^{\prime 9}$ A ruler's ability to lead in a selfless way is contingent upon his understanding that he himself was first served by the Son of God.

Luther's advice to earthly leaders concerning advisors and criminals emphasizes intelligent, creative thought on the leader's part. He challenges the princes of his day to examine all of the advice that comes to them, regardless of the source..$^{70}$ He claims that good and bad advice can come from well-respected people as well as from those who are despised. "(Gott) hat einmal durch einen Esel geredet, deshalb ist kein Mensch zu verachten, wie gering er sei. Umgekehrt hat er den höchsten Engel vom Himmel fallen lassen, deshalb ist auf keinen Menschen zu vertrauen, wie klug, heilig und groß er sei." ${ }^{71}$ Just as a ruler must be clever in the way he receives advice, he must also be wise in how he administers justice. "Hier muß er gar klug und weise sein, auf dass er ohne der andern Verderben strafe."72 Luther wanted earthly authorities to consider the consequences of a given punishment before acting in order avoid doing more harm than good when meting out consequences. He believed that each crime should be examined separately,

\footnotetext{
68 Mark 10:45.

${ }^{69}$ Luther, Von weltlicher Obrigkeit, 21.

${ }^{70}$ Luther, Selections from his Writings, Secular Authority, 396.

${ }^{71}$ Luther, Von weltlicher Obrigkeit, 39; See appendix B.

72 Luther, Von weltlicher Obrigkeit, 41.
} 
rather than administering the law blindly, as if every case of thievery or murder is exactly the same. ${ }^{73}$ In Luther's opinion, a person's motive and the effect of their actions on the community at large should be taken into consideration.

According to Luther, subjects, or common people, should also display a combination of the two kingdoms by obeying both God's law and earthly law. Luther advised the average person to live according to Christian principles and, like the princes, to think for themselves. ${ }^{74}$ Luther insists that God gave governments to mankind in order to help and protect people. If they fail to do so, the citizens should protest in a non-violent manner..$^{75}$

Luther recommended that the people use peaceful means to influence the government, but at the same time he threatened the authorities with the new found ability of the common man to think. ${ }^{76}$ Communities should, for example, use this ability to think in regards to questions about war. Luther believed that a man should fight in battles and offer his life, but only if there is an unavoidable reason for the conflict. He did not believe that a person should represent an unjust cause and encouraged his fellow man not to fight if they believed that it was against God's will. ${ }^{77}$

Luther believed that the effect of the Kingdom of God on the Kingdom of the World could be notably positive, because adherence to the principles that govern

${ }^{73}$ Luther, Selections from his Writings, Secular Authority. 401.

74 Ibid. 385.

75 Ibid. 388.

${ }^{76}$ Luther, Von weltlicher Obrigkeit, 34: To this effect Luther says: "der einfache Mann wird verständig" and "Man wird nicht, man kann nicht, man will nicht eure Tyrannei und Mutwillen auf die Dauer leiden!"

77 Luther, Selections from his Writings, Secular Authority, 398-9. 
God's Kingdom decreases the demand put on earthly governments by discouraging criminal and revengeful behaviors. ${ }^{78}$ Luther argues that if individuals were to hear and obey God's voice, the justice system would not need to process as many people. If people were to follow the advice given at the beginning of the treatise Von weltlicher Obrigkeit, that is, that Christians should not fight against their adversaries, fewer people would sue each other. ${ }^{79}$ The world could benefit greatly from the influence of this teaching, not only because the courts would have less demand put on them, but also because people who are under the influence of the Kingdom of God are more likely to serve their fellow man selflessly and completely, according to Luther. They strive to think of others in order to help people to the best of their abilities.80 "In Bezug auf dich und das Deine hältst du dich nach dem Evangelium und leidest Unrecht als ein rechter Christ; in Bezug auf den andern und das Seine angeht hältst du dich nach der Liebe und leidest kein Unrecht gegen deinen Nächsten." ${ }^{11}$ In this way, Luther recommends a two-fold approach to wrong-doing: on the one hand, a Christian is to overlook offenses against himself, and on the other hand, a Christian should fight for the rights of others, not overlooking offenses, but insisting that communities and individuals treat each other with respect and dignity. In summary, the Kingdom of God, according to Luther, consists of the souls that seek and listen to the voice of God. The Kingdom of the World consists of various governments or governing entities that rule over the physical being and

78 Luther, Selections from his Writings, Secular Authority, 369.

79 Ibid. 364.

80 Ibid. 375.

${ }^{81}$ Luther, Von weltlicher Obrigkeit, 16. 
possessions of a person. The Kingdom of God helps the Kingdom of the World because people who accept God's wisdom can serve better both as governing authorities and common citizens. The Kingdom of the World helps the Kingdom of God in that it maintains order on earth and reduces immoral and harmful behaviors. Both kingdoms have the responsibility of helping and protecting people. Luther emphasized that "man niemand zum Christentum zwingen kann," just as no one can be prevented from being a Christian. ${ }^{82}$ Therefore, governments of the world must not try to force people either to believe in or not to believe in God. Although, Luther argues, a person's life will be richer if invested in both kingdoms, it is still important to differentiate between the two spheres. This helps both churches and governments to avoid senselessly trying to "establish a spiritual rule over souls." 83 Although many scholars refer to the church and state when discussing the Two Kingdoms Theory, Luther did not depict the church as the Kingdom of God and earthly governments as the Kingdom of the World. The picture painted by Luther places the church and state together in the Kingdom of the World. Luther's definition of the earthly kingdom is sphere in which God gives authority to mankind to maintain order in the world. The Kingdom of God, on the other hand, is untouchable: God alone has power in this realm. These two spheres are paradoxically connected and yet separate, just as the soul and body remain distinct and yet interconnected. Luther argues that a healthy balance of obedience towards

82 Luther, Von weltlicher Obrigkeit, 21.

${ }^{83}$ Luther, Selections from his Writings, Secular Authority, 386. 
earthly authorities, church and state included, and towards God is necessary for individuals and societies to function in a successful and healthy manner. 


\section{The Traditions and Literature out of which Luther's Two Kingdoms Theory Evolved}

Luther was, as Susan Karant-Nunn described, "a man of his age." ${ }^{84}$ Although he was a key figure in the Reformation who initiated significant changes in society, he was still strongly influenced by the times in which he lived. Therefore he thought and functioned within the context of the system of $16^{\text {th }}$ century Germany insofar as that, when he crossed boundaries, the boundaries he crossed, be they spiritual or political, were those relevant to the times. To understand his works, one must examine his culture and the literature that influenced him. Political and religious customs in $16^{\text {th }}$ century Germany were closely intertwined with each other, leaving little or no definition between the two. Luther clearly and explicitly criticized the mixing of the responsibilities of the church verses those of the state.

Fein haben sie es umgekehrt: Innerlich sollten (Papst und Bischöfe) die Seelen durch Gottes Wort regieren, so (aber) regieren sie auswendig Schlösser, Städte, Land und Leute ... die weltlichen Herren (sollten) Land und Leute äußerlich regieren. Das lassen sie. Sie (wollen) widersinnig ... geistlich über Seelen regieren. ${ }^{85}$

His criticism against the intermingling, or as he put it, the upside-down positioning of the two primary powers of his time, earned him the reputation of being a forward thinker, leading to the concept of the separation of church and state. This claim is difficult to prove, however, in light of his primarily religious advice to the political authorities. In order to better understand the basis of Luther's political and

${ }^{84}$ Karant-Nunn, Reformation of Ritual, 7.

85 Luther, Von weltlicher Obrigkeit. 28. 
religious ideas, this thesis will explore the religious customs of his times, the influential works of St. Augustine, and the Bible, known to Luther as the "Word of God."

\subsection{Religious Customs of the $16^{\text {th }}$ Century and Control of the People}

The church of Luther's day exercised great power over the people primarily through the use of threat of eternal hell fire. The majority of the people had been convinced that the Pope, bishops, and priests held the keys to eternal life and eternal punishment. ${ }^{86}$ The citizens and the nobility had been taught that representatives of the Catholic Church could act in the place of God and that the fate of the eternal soul depended on the rituals they performed. The Roman Catholic Church claimed that the seven sacraments, a complex series of gestures, prayers, exorcisms, and the use of various props, such as robes, salt, water, oil and incense, were commanded by God and that without them, one would go to hell. They went on to say that only people who were approved and sanctioned by the Roman Catholic Church could perform these "magic tricks," as Martin Bucer, Luther's colleague and fellow reformer, called some parts of the rituals. ${ }^{87}$

86 Karant-Nunn, Reformation of Ritual, 92.

${ }^{87}$ Quote from English source. Ibid. 59. 
Although Martin Luther often mocked the superstitious nature of these rituals, he did not reject them completely ${ }^{88}$ He accepted only two of the seven rituals as true sacraments: baptism and communion. ${ }^{89}$ For Luther, a sacrament was a ritual specifically commanded by God for all Christians. The other five: confirmation, holy orders, confession, anointing of the sick, and marriage, he believed were either not commanded by God or were not exclusively Christian. ${ }^{90}$ However, Luther still considered these rituals to be good opportunities to offer religious instruction to the people, and thus attached a certain value to the traditions. Concerning confirmation, the process of teaching a young person the basics of the Christian faith and then asking them to publicly "confirm" their baptism, he said that he would allow the ritual, but only if people knew that "God did not say anything about it." ${ }^{\prime 1}$ Similarly, Luther believed it to be necessary for Christians to confess, or admit to, their sins and shortcomings, but he claimed that this could be done before any believing person in order to receive forgiveness from God. Again, according to Luther, although a priest is a person who has been given specific duties by the congregation, in essence all Christians are priests. ${ }^{92}$ His rationale was that all people have access to God and the responsibility to make a connection for themselves and for others with their Creator.

According to Luther, marriage was a part of the Kingdom of the World, due to the fact that it is not an exclusively Christian institution. Luther did not see a need

88 Karant-Nunn, Reformation of Ritual, 150.

89 Ibid. 50.

90 Bainton, The Reformation of the Sixteenth Century, 46-7.

${ }^{91}$ Quote from English source. Karant-Nunn, Reformation of Ritual, 67.

92 Bainton, The Reformation of the Sixteenth Century, 47 
for the church to play a large role in the marriage ceremony itself. ${ }^{93}$ He believed that the church should bless a wedding if the couple so desired, and just as with confirmation, he considered the wedding to be a good opportunity to teach God's word. Nevertheless, in his opinion marriage was still not a sacrament. In light of his indifference to marriage, it is ironic that his own marriage to Katharina von Bora effected the greatest change on the status of marriage during the $16^{\text {th }}$ century. ${ }^{94}$ Previously, the oath of celibacy amongst the clergy was valued more than the state of marriage. Even if a priest were to break his vow of celibacy, that would still be more honorable than being married. ${ }^{95}$ Although Catholics recognized marriage as a "sacrament," its status remained lower than that of celibacy.

In his treatise, On Monastic Vows, Luther argued that vows of celibacy were, in fact, contrary to the teachings of the Bible and counterproductive to a "useful life in society." ${ }^{\prime 96}$ After Luther's own marriage in 1525, and his claim that the practice of celibacy did not indicate a higher level of existence than the state of marriage, marital life finally assumed a reputation of respectability amongst religious people. The newly discovered holy nature of marriage did not develop as a result of more pompous or more complicated wedding rituals, but instead it came about through the example of respected reformers like Luther and Calvin, who decided to marry because they were convinced that the institution of marriage was honorable for

93 Karant-Nunn, Reformation of Ritual, 13.

94 Ibid. 6.

95 Ibid. 6.

${ }^{96}$ Quote from English source. Spitz, The Protestant Reformation, 111. 
clergy and non-clergy alike. It this way, celibacy lost its special standing among many Christians during the Reformation.

Although Luther accepted baptism and communion as sacraments, he still believed that there should be significant changes in how they should be celebrated. He eliminated many elements that he viewed as superstitious, such as an exaggerated emphasis on the devil in the form of exorcisms during infant baptism and the use of spittle and oil during the ritual. ${ }^{97}$ Luther did not, however, think that rituals should be altered too quickly, but that due to "weak consciences" the change should occur gradually over time. In his reworking of the ritual of baptism, it is obvious that he was not willing to compromise concerning the "Word of God." ${ }^{98}$ His focus was on the use of the vernacular, in order to be sure that the parents and witnesses at the baptism knew what the Bible says, rather than focusing on the theatrics of the ritual. First by reading the plain "Word of God," Luther believed that it would later be easier for the common folk to let go of the more superstitious elements of the ritual of baptism.

Luther's influence on the traditional beliefs surrounding communion, or Eucharist, was just as powerful as the effect he had on the other church practices. In regards to all rituals, he believed that a person's inward belief, and not the outward procedure, is what counts before God. ${ }^{99}$ The Catholics of Luther's day, as well as present-day Catholics, believe that during the Eucharist, the ritual in which bread and wine are consumed in memory of Jesus' death, the bread and wine become the

97 Karant-Nunn, Reformation of Ritual, 51.

98 Ibid. 51.

99 Ibid. 115. 
literal flesh and blood of Christ by means of a miracle. This is referred to as transubstantiation. Luther countered this belief with the idea that Christians should recognize that Christ is present in the ritual, but that this presence in the bread and wine is to be understood less as physical and more as spiritual. ${ }^{100}$ This teaching was viewed as radical in Luther's time in spite of the fact that Jesus had previously explained it in the same way when he said, "Whoever eats my flesh and drinks my blood remains in me and I in him,"101 but clarified that what he was speaking of was spiritual in nature: "The words that I have spoken to you are spirit and they are life."102 Although the Catholic Church of Luther's day considered his teachings on the Eucharist to be radical and even heretical, Luther's focus on the spiritual presence of Christ in the bread and wine takes the whole Biblical perspective into account, rather than taking Bible texts out of context.

Again, Luther returns to the Bible when addressing the anointing of the sick, which is called extreme unction when performed just before death. Luther taught that a person's salvation was not dependent on extreme unction being performed when someone dies, and yet he believed that it could provide a comfort when a person is passing away. ${ }^{103}$ Karant-Nunn asserts that "Luther himself had no fear of death." ${ }^{104}$ His confidence came from his understanding of the Bible. Therefore he encouraged priests and pastors to speak to their congregations in the vernacular so that they, too, could understand the "Word of God" and thus be freed from the fear

\footnotetext{
100 Karant-Nunn, Reformation of Ritual, 114.

101 John 6:56.

102 John 6:63.

103 Karant-Nunn, Reformation of Ritual, 146.

104 Ibid. 149.
} 
of death. ${ }^{105}$ According to Luther, all people continue to commit new sins even if they believe in God and try to be "good." One always falls short in the process of becoming a Christian, but belief in God and the fact that he continually forgives us and reconciles us to himself will save us. ${ }^{106}$ Because Luther believed in the power of God's Word, he wanted all people to hear its message in their own language. Therefore he strove to take the emphasis off of the rituals and put it on the "Word of God" as it is found in the Bible. ${ }^{107}$

In this and countless other ways, Luther took power away from the priests and gave it to God and individuals. ${ }^{108}$ Luther did not vest his belief in the Catholic Church per say, but he did believe in the "true church."109 In the treatise Wider das Papsttum zu Rom (1525), Luther introduced his theory distinguishing between an outer, worldly organization called "the church," and an invisible spiritual community bound together by faith in Christ that he called the "true Church." According to Luther, the "true Church" cannot be identified or controlled by any element of the Kingdom of the World, because physical bodies and/or property of people are not the materials that make up the "true Church." This church consists of the souls of people who believe in God, and earthly powers cannot control, organize, or change the human soul.

The Catholic Church of Luther's time claimed to have the ability to forgive sins and release people from purgatory, a place where a person is temporarily

105 Karant-Nunn, Reformation of Ritual, 50.

106 Ibid. 150.

107 Thompson, The Political Thought of Martin Luther, 30.

108 Karant-Nunn, Reformation of Ritual, 94.

109 Thompson, The Political Thought of Martin Luther, 33. 
punished after death for his or her sins on earth. Documents, stating the promised release of a soul from punishments after death, were called "indulgences," and were most often given to people, coincidentally, after they had given money to the Catholic Church. ${ }^{110}$ The church received large amounts of money through the sale of indulgences, so much so that they began to finance major building projects with the surplus. ${ }^{111}$ The idea that one can buy forgiveness of sins from the church, or that a person can purchase forgiveness from God with money, sparked such a heated controversy that it became known as the "Leidenschaften der Ablässe," or the "passion of the Indulgences."112 This passionate debate led Luther to nail the "95 Theses Against Indulgences" to the church door in Wittenburg in 1517,113 six years before he wrote Von weltlicher Obrigkeit.

In his struggle against the sale of indulgences, Luther began to distinguish between the two kingdoms insofar as that only God, who needs no money from us, can forgive matters of the soul. According to Luther, the soul remained in God's kingdom and not under the jurisdiction of the church, which is a worldly organization. However, it can be quite confusing when one reads Luther's claim in Von weltlicher Obrigkeit that the Pope and the bishops "die Seelen durch Gottes Wort regieren (sollten)."114 The key in this statement is that the soul can only be ruled by the "Word of God." In the end the person does not rule the soul, but it is God's living word that has access to the innermost soul. Luther's explanation of this

110 Bainton, The Reformation of the Sixteenth Century, 37.

111 Ibid. 38.

112 Thompson, The Political Thought of Martin Luther, 31.

113 Karant-Nunn, Reformation of Ritual, 95.

114 Luther, Von weltlicher Obrigkeit, 28. 
point reads: "(Priester und Bischöfe) sind nicht höher noch besser vor andern Christen. Darum sollen sie auch kein Gesetz noch Gebot über andere aufstellen ohne derselben Willen und Erlaubnis, sondern ihr Regieren ist nichts anderes als Gottes Wort treiben."115

Luther's focus on the accessibility of the Bible and his devaluing of Catholic rituals was a way of differentiating between the Kingdom of God and the Kingdom of the World. The Catholic Church had, through the use of sacraments and indulgences, sought to maintain authority and control over the very soul of a person. Luther believed that only God has control over a person's eternal destiny and that through grace, or unmerited love, God offers a home in heaven to all who believe in his son, Jesus Christ.

\subsection{Augustine and His Influence on Martin Luther}

In principle, Martin Luther rejected the authority of the Roman Church, and yet he continued to celebrate the sacraments and encouraged the people to respect the temporal authority of the church, as long as it was not in direct conflict with the Word of God. Luther accepted only the Bible as a direct depiction of God's will and authority. For advice as to how temporal authorities should function, Luther did not depend on anything that had been written during the thousand years before his time. Instead he referred back to Bishop Augustine of Hippo (354-430), who had

115 Luther, Von weltlicher Obrigkeit, 335. 
written a collection of 22 books called The City of God. ${ }^{116}$ His respect for Augustine came from the belief that they were of like mind in that they both drew their conclusions from the Old and New Testaments. ${ }^{117}$ They both claimed that there are no outer signs that prove a person's faith ${ }^{118}$ and they emphasized inward belief. ${ }^{119}$

In practice, Luther followed Augustine's lead in that he did not insist that the people of God agree on details, like the specific procedures for baptism or Eucharist, in order to live a life of faith in God. ${ }^{120}$ Neither Augustine nor Luther believed that all Christian communities should be carbon copies of each other. Still, both men argued their point of view concerning church doctrines passionately in order to convince the authorities and the people of the nature of God's kingdom.

Although Luther agreed with Augustine's theories presented in The City of God, Luther developed his Two Kingdoms Theory in a different way, especially in regards to his definition of the spheres. There are many ways in which theologians divide and define the universe: physical and spiritual, temporal and eternal, good and evil, known and unknown, etc. Augustine defined the City of God as everything that is good and the Earthly City as everything that is evil. Therefore, physical and spiritual elements exist in both realms. According to Augustine, the "Earthly City" refers to everything that is bad in both the earthly and spiritual spheres and the

\footnotetext{
116 Luther, Selections from his Writings, Secular Authority, 3.

117 Ibid. 376; Augustine, The City of God, Book XX, Ch. 4.

118 Luther, Selections from his Writings, Secular Authority, 368; Augustine, The City of God, Book XIX, Ch. 19.

119 Karant-Nunn, Reformation of Ritual, 95. Augustine, The City of God, Book XVI, Ch. 4.

${ }^{120}$ Karant-Nunn, Reformation of Ritual, 117-118. Augustine, The City of God, Book XI, Ch. 32.
} 
"City of God" is everything good, regardless of whether it is spiritual or physical.121 The various names that he ascribed to the spheres reveal his feelings about these "cities." The Earthly City is called by different names: religionless city, godless city, and city of the devil. It is characterized by selfishness, confusion, and the fate of eternal punishment. ${ }^{122}$ The people who belong to this sphere oppress each other and tend to believe the lie that sin can deliver happiness. ${ }^{123}$ On the other hand, he calls the City of God "our" city, house of God, holy city and paradise. Healing, forgiveness, love, eternal joy and eternal life are the elements that are found in the City of God. ${ }^{124}$ According to Augustine the people of this city are humble and they long to praise the true, eternal God. ${ }^{125}$ He noted that people from both cities experience pleasant and unpleasant circumstances and emotions, but the result of these experiences is different. ${ }^{126}$ Just as fire purifies gold, but destroys straw, so are the effects of life positive for the citizens of God's city and negative for those who reject God. ${ }^{127}$ In this way, Augustine did not teach that the life of a Christian would be free of all problems, but he claimed that difficulties in the Christian life produce positive effects in eternity. On the other hand, positive events in the life of those who reject God are fleeting and of no eternal value.

Luther agreed with Augustine's point of view, but in order to achieve his goal of addressing the authorities of $16^{\text {th }}$ century Germany, he sought a new way to

\footnotetext{
${ }^{121}$ Augustine, The City of God, Book XIV, Ch. 2I, Book XXII, Ch. 11.

122 Ibid. Book XVIII, Ch. 40. Book XXI, Ch. 1. Book XII, Ch. 1. Book XVI, Ch. 4.

123 Ibid. Book XVII, Ch. 2. Book XIV, Ch.4.

124 Ibid. Book XV, Ch. 1; Book XV, Ch. 6; Book XVII, Ch. 20; Book XIX, Ch. 11.

125 Ibid. Book XVI, Ch. 4.

126 Ibid. Book XIV, Ch. 9.

127 Ibid. Book XXI, Ch. 26.
} 
divide the two spheres. Instead of dividing between good and evil, he explored the realm in which God delegates his authority and the realm in which he rules alone. In examining these spheres, Luther criticized the political and religious climate of $16^{\text {th }}$ century Germany. The Catholic Church of Luther's day was large and politically powerful, leading Luther to feel the need to explain that the church could not invent new commandments and then attribute them to God. Both religious and political authorities thought that they could exercise control over the human soul. ${ }^{128}$ Luther wanted to remove the credibility of this claim. At the same time, he wanted to prove that it is God's will that governing authorities are in the world and that, in spite of the freedom enjoyed by Christians, they should still be obedient to these authorities. ${ }^{129}$

Similarly, Augustine reacted to the religious and political situations of his time. But the realities of the fourth and fifth centuries were different than those that Luther addressed. In the first ten books of The City of God, Augustine criticizes the idolizing of Roman gods as well as theories of many philosophers. Although he is sharply critical of these theories and practices, his book offers an amazing tour through the history of the early Christian era, exploring and interpreting myths and philosophical reasoning. In contrast to Luther's criticism, which is often full of sarcasm and name-calling, Augustine's criticism is highly logical and organized.

Augustine spoke publically and wrote in Latin, which he had learned in school. A mere 400 years after the birth of Jesus Christ, the Latin employed by

${ }^{128}$ Luther, Selections from his Writings, Secular Authority, 366, 368.

129 Ibid. 366. 
Augustine had a modern, distinctly Christian feel to it. ${ }^{130}$ It was a clear language that was understood in several countries and therefore Augustine could reach many people with its use. 1100 years later, the Catholic Church still used Latin, not because it was modern nor widely understood, which it was not, but in order to maintain a continuance of mystical church rituals and history. Although Luther held strongly to the content of Augustine's works, he agreed with the majority of the common German folk that more of the vernacular should be used during church services rather than Latin.

Luther identified with Augustine because he, too, had fought against a more powerful sect of the church. The Donatists represented the majority in the African Christian Church, but Augustine held passionately to the Caesilianists, who were continually fighting against the Donatists over matters of church doctrine as well as struggling for political control. ${ }^{131}$ Augustine wrote a song, almost 300 lines long, called "Psalm Against the Donatists" in order to confront his religious opponents. ${ }^{132}$ However, in all of his arguments Augustine presented himself as simultaneously passionate and logical, whereas Luther often rejected logic. ${ }^{133}$ Luther believed that human reasoning has no place in spiritual matters. Cargill Thompson states that Luther's negative feelings concerning reason applied to spiritual matters were so strong that he referred to it as "the devil's whore."134 Luther also differed with

130 O’Donnell, Augustine, 117.

131 O'Donnell, Augustine, 14, 110, 165.

132 Ibid. 117.

133 Bainton, The Reformation of the Sixteenth Century. 36.

${ }^{134}$ Quote from English source. Thompson, The Political Thought of Martin Luther, 81. 
Augustine in that he attributed God with evil intentions, whereas Augustine claimed that God is not to be blamed for anything bad or anything lacking in the world. ${ }^{135}$

Augustine emphasized the strength of good and depicted evil as powerless.

These Augustinian theories had a positive influence on Luther, but this emphasis on what is good did not remove Luther's cynical nature. Augustine claimed that in spite of its existence, evil is not natural. He also claimed that God always has the ability use bad decisions to do something good. ${ }^{136}$ Augustine believed that, whereas mistakes and evil can only exist within the context of good, that which is good, can exist on its own. ${ }^{137}$ He went on to say that some things people perceive as "bad" are in fact not bad, but that they need to ask God, "What is the purpose in this?" in order to find out how God wants a certain thing or situation to be used.138

In spite of Luther's persistent cynicism in the face of Augustine's positive theories, one should not underestimate Augustine's influence on Luther. Although The City of God does not present the exact same theory as Luther's Two Kingdom Theory, it still provided a solid starting point from which Luther could address the religious and political circumstances of his time. The Catholic Church believed in an unbroken succession of Popes from St. Peter to the Popes of Luther's day, as well as bishops from St. Augustine to the bishops of their day, but Luther believed that St. Augustine's teachings and belief in his God was more important than the succession

\footnotetext{
135 Luther, Von weltlicher Obrigkeit, 6: "Denn Gott der Allmächtige hat unsere Fürsten toll gemacht." Ibid. 28: "Gott hat sie in verkehrten Sinn gegeben." Augustine, The City of God, Book XII, Ch. 14.

136 Ibid. Book XI, Ch. 17.

137 Ibid. Book XII, Ch. 3.

138 Ibid. Book XI, Ch. 22.
} 
of power. Augustine's writings support the view that the succession of Popes or bishops is not important in light of faith in Christ: "We do not believe Peter, but in whom Peter believed."139 Luther's famous quote attributed to his speech before the diet of Worms, a church council, was borrowed from Augustine's book, Confessions. As he defended his faith under the threat of excommunication or death he said, "Here I stand, I can do no other."140

Luther believed that the Catholic Church had abandoned the faith taught by Augustine. Among other works, Luther's Von weltlicher Obrigkeit was an attempt to return to the teachings of Augustine and the Bible. Luther valued Augustine's works, while rejecting the writings of the scholars in the Catholic Church who came after Augustine. It is apparent that Luther was not lacking in self-confidence: he boldly placed his writings on the same level with those of Augustine's, dismissing the1100 years of Christian works that intervened between St. Augustine and himself. Although Luther pictured himself as continuing St. Augustine's traditions of faith, he did not merely repeat what Augustine had written, but modified and developed the themes found in City of God to apply to the German society of the $16^{\text {th }}$ century. For this reason, Luther focused on the two spheres in terms of the proper use of authority, rather than exploring the nature of good and evil, as did Augustine in City of God. By developing Augustinian ideas for his culture, Luther believed that he was continuing a faith tradition that had been abandoned by the church of his day.

139 Augustine, The City of God, Book XVIII, Ch. 54.

140 Quote from English source. O'Donnell, Augustine, 53. 


\subsection{The Influence of Holy Scriptures on Luther's Two Kingdom Theory}

The effect of the Holy Scriptures on Martin Luther's political and religious teachings was much greater than any other influence in his life. He treated the religious customs of his times as optional: he reacted against them and yet wanted to retain certain elements of the rituals. In contrast, the Bible served as his true foundation on which he built his arguments for the treatise, Von weltlicher Obrigkeit. Even Augustine's influence pales next to that of the Bible. Augustine was an important example for Luther, but he did not claim to base his authority on Augustine, but rather on the Holy Scriptures alone. Just as Augustine had said, "We do not believe Peter, but in whom Peter believed," Luther confessed, "wir sind nicht getauft auf Könige, Fürsten, noch auf die Menge, sondern auf Christus und Gott selbst. Wir heißen auch nicht Könige, Fürsten oder Menge, wir heißen Christen."141 Although Augustine's influence gave Luther's works a certain flavor, he quoted him only once in the treatise Von welticher Obrigkeit, whereas he quoted the Bible more than 90 times. ${ }^{142}$ The "Word of God" served not only as the foundation, but also as the building material, source, process and purpose of this work.

In order to make sense of the all-important nature of the God's word for Luther, one must first understand how Luther viewed the twofold meaning of the "Word of God." The first level is easy to understand: the "Word of God" is the

${ }^{141}$ Luther, Von weltlicher Obrigkeit, 26.

142 Ibid. 28. 
written Bible, consisting of the Old and New Testaments. The Old Testament is made up of the five books of the Torah in which the Jewish Law is found, 12 historical books, five instructional books and psalms, and 17 books of prophesy. The New Testament consists of five historical books, 21 letters and one book of prophecy. ${ }^{143}$ Although Luther did not value the books of the Bible equally, he was not willing to leave any of the books out, but considered it essential to count all the books of the Bible as the final authority. ${ }^{144}$ This was how he answered the questions of his critics: "By what authority do you do these things? Are you alone clever?" His answer was that he acted "by the authority of the Holy Scriptures."145 Whether or not his critics had a heart-felt respect for the Bible, they were unwilling to publically reject it as a foundation for thought. Luther's claim that he was acting by the authority of the Holy Scriptures caused his critics to take him seriously, although they continued to disagree with him.

The second and more abstract level of Luther's concept of God's word is present in the person of Jesus Christ. Luther believed that God had revealed himself physically through Jesus Christ and that he is eternally active on a personal level in the immortal spirit of his son Jesus. ${ }^{146}$ Therefore, the authority on which Luther built the Two Kingdoms Theory was not only a written document, but also the leading of God through the "Living Word," Jesus.

143 Die Bibel nach dem Übersetzung Martin Luthers.

144 Bainton, The Reformation of the Sixteenth Century, 45.

145 Quote from English source. Ibid. 44.

146 Ibid. 45. 
The first sense of the "Word of God" is easy to identify in the text, Von weltlicher Obrigkeit. Luther wrote this treatise in three main parts, focusing on different Bible verses for each section. The first part presents Luther's reasoning in proving that God has established the Kingdom of the World in the form of earthly authorities in order to protect the innocent and punish the guilty. The second part addresses the limits of the powers of this world and claims that humans cannot rule over each other's souls. These first two sections are argued using both the Old and New Testaments, but they focus most heavily on verses out of the New Testament. Luther refers to the book of Romans, chapter 13, First Peter, chapter 2, and Matthew, chapter 5 respectively seven, three and six times. ${ }^{147}$ The first two excerpts express the idea that one should be obedient to earthly authorities because they are established by God in order to punish evil and protect those who do what is right. The third verse from the book of Matthew is a quote from Jesus saying that one should not resist evil, but that "if someone strikes you on the right cheek, offer him the other also."

Luther saw a contradiction in these verses: God established authorities to punish evil, but asks that we not resist evil. Luther used the term "das Schwert" to refer to worldly authorities in order to emphasize the punishment aspect. Luther posed the question: how can Christians use "das Schwert" if they are not supposed to resist evil? His answer is that one should only use earthly defenses in order to help others, and not for his or her own benefit. Luther's conclusion on this matter according to what he found in the Bible says, "das Schwert soll kein Christ für sich 
un seine Sache führen noch anrufen; sondern für einen andern kann und soll ers führen und anrufen, damit der Bosheit gesteuert und die Rechtschaffenheit geschützt werde." ${ }^{\text {148 }}$ The New Testament verses used in the first two sections of Von weltlicher Obrigkeit are an example of that which differentiates Christianity from other monotheistic religions. The command not to defend one's self and to love one's enemy is distinctly Christian, based on Christ's example of being willing to die in order to save mankind. Wielding "das Schwert," or making use of earthly law and order, to help each other is, according to Luther, an expression of love for one's neighbor.

The third section of the treatise refers, surprisingly, almost exclusively to verses from the Old Testament. Luther mentions the New Testament only three times, and even these verses do not address the subject of the third section, which is advice for people who possess political power. ${ }^{149}$ The first reference to the New Testament, Luke 22: 25 , is a commentary on the character of earthly authorities. The second, John 3: 20-21, shows that advisors who hide their dealings are not to be trusted, and the third, Acts 5: 29, says that people should obey God rather than men. The majority of the advice and examples for earthly authorities in section three come from the Old Testament, because it has much more to say about earthly law.

Jesus, the focus of the New Testament, also referred to as "the Word made flesh," does not seem to be terribly interested in politics. ${ }^{150}$ It is difficult to find any political advice in the teachings of Jesus, although Christ's anecdotes and sermons

148 Luther, Von weltlicher Obrigkeit, 22.

149 See appendix D.

150 John 1:14. 
are full of personal advice. Luther believed that Jesus as God's "Word" was not only a man who lived 1,500 years ago, but was a present, living force in the life of a Christian. This is the "Word" that had the greatest influence on Luther. The "Word" is this man who, rather than addressing politics, speaks directly to the heart of his listener. He was Luther's hero and therefore Luther imitated him when he began his advice to the princes: "(ich) weiß einem Fürsten kein Recht vorzuschreiben, sondern will nur sein Herz unterrichten."151 His instruction was that they should trust God and lead their people lovingly through prayer and the wisdom that God gave them and to remain independent, critical thinkers. ${ }^{152}$ The stories that he presented to the authorities pointed out that a new, confusing situation lies behind every bend in the road and therefore those with power should never stop thinking, praying, and empathizing with those in their charge. There are no formulas, only engaged, active living. That is why Luther did not overlook the "Living Word" when referring to the written "Word of God," and he encouraged others to do the same. Luther's Two Kingdoms Theory was based primarily on his personal interpretation of verses found in the Old and New Testaments. The advice he presented to church and state officials as well as to common people, to make one's relationship with God a priority, is an acknowledgment of the living "Word of God," or Jesus Christ. ${ }^{153}$ His advice towards the institution of earthly governments and churches was one of balance. Based on the Bible, he argued the legitimacy of these organizations, but insisted that their power is limited and does not extend to

${ }^{151}$ Luther, Von weltlicher Obrigkeit, 38.

152 Ibid. 37-45.

153 Ibid. 43, 31, 1 John 2:4-6, Acts 5:29. 
matters of eternal judgment. Rather than putting an end to questions about the role of church and state, Luther's Von weltlicher Obrigkeit sparked a 500-year discussion amongst theologians and politicians concerning the specific nature of earthly authorities. 


\section{Luther's Two Kingdoms Theory During the Time of \\ National Socialism:}

\section{The Interpretations and Applications of Barth and Bonhoeffer}

Although the effects of the Reformation were felt throughout the entire Christian world, the influence of Martin Luther was most notable in Germany. Martin Luther translated the Bible into German and wrote literature aimed specifically at the German population. ${ }^{154}$ During his life and especially after his death, Luther became a hero for the Germans who had changed the world and an important part of German identity became linked with this reformer.

After World War I the National Socialist Party (the Nazis) rose to power in Germany. One of the goals of the Nazis was to present themselves as distinctly German. In order to successfully present the picture of a thoroughly German citizen, they had to come to terms with Luther's teachings. Hanns Rückert, a German theologian in Nazi Germany, was, among others, helpful in achieving this goal. Siegele-Wenschkewitz explains in her book, Theologische Fakultäten im Nationalsozialismus, that the figure of Luther was used by Rückert to unite being a Christian and being a Nazi into one entity. ${ }^{155}$ Siegele-Wenschkewitz claims that the National Socialists based their "anti-democratic, anti-liberal, anti-enlightenment, and above all the anti-Semitic way of thinking" on Luther's theology. The Nazis then presented their racist version of Lutheran theology as a kind of "people's theology"

154 Luther, An den christlichen Adel deutscher Nation.

155 Nicolaisen and Siegele-Wenschkewitz, Theologische Fakultäten im Nationalsozialismus, 126. 
in the newspaper, "Deutsche Theologie."156 To do this, the Nazi's had to ignore and suppress much of Luther's writings. However, and unfortunately, they were able to find other writings from the famed German reformer that supported the racist ideas that they presented.

At the same time that the Nazis were developing racist theology based on Martin Luther, a young theologian by the name of Dietrich Bonhoeffer was actively engaged in refuting their claims. Bonhoeffer, who was born on February 4, 1906 in Breslau along with his twin sister, Sabine, earned his doctoral degree in theology at the age of 21 and became the vicar of a German congregation in Spain. ${ }^{157}$ He went on to publish post-doctoral work and serve in Evangelical congregations in Germany, England and the United States. Perhaps the fact that his twin sister, Sabine, married a Christian man with a Jewish heritage made him particularly sensitive to the racist doctrines being developed by members of the Evangelical Church in the name of Martin Luther.

Long before the dangerous side of Nazi ideologies became evident to even his racially Jewish friend and colleague, Franz Hildebrandt, Bonhoeffer viewed the National Socialist Party as dangerous and unstable. ${ }^{158}$ Bonhoeffer examined and studied the teachings of Luther, not only because he truly believed in the principles of the reformer, but in order to have the ability to respond to the Nazis. He believed

156 Nicolaisen and Siegele-Wenschkewitz, Theologische Fakultäten im Nationalsozialismus, 131.

157 Metaxas, Pastor, Martyr, Prophet, Spy, 8, 67-68.

158 Ibid. 196. 
that the Evangelical Church had weakened Christianity in Germany by its false interpretations of Luther's teachings. He described the situation with vivid words:

Wie die Raben haben wir uns um den Leichnam der billigen Gnade gesammelt, von ihr empfingen wir das Gift, an dem die Nachfolge Jesu unter uns starb. Die Lehre von der reinen Gnade erfuhr zwar eine Apotheose ohnegleichen, die reine Lehre von der Gnade wurde Gott selbst, die Gnade selbst. Überall Luthers Worte und doch aus der Wahrheit in Selbstbetrug verkehrt. ${ }^{159}$

Bonhoeffer believed that the modern Germans had traded discipleship to Jesus in exchange for Luther's words. By repeating the Lutheran mantra that one is saved by grace alone, Lutheran Christians in Germany believed to have achieved the ability to stand unaccountable before God. By removing a sense of personal responsibility in the religious context, they superimposed "justification of the sin" in Luther's teachings. However, by doing so, they turned Luther's formula into the opposite of what Luther had actually taught. ${ }^{160}$ Upon reviewing the situation in Germany in 1937 Bonhoeffer said, “Es ist erschreckend, zu erkennen, was daran liegt, in welcher Weise eine evangelische Wahrheit ausgesprochen und gebraucht wird." ${ }^{161}$ Although Bonhoeffer did not agree with all of Luther's theories, he found the majority of Luther's teachings to be exemplary. The Nazi interpretations of church doctrines were repugnant to Bonhoeffer and he found the church's role in the Third Reich demoralizing.

159 Bonhoeffer, Nachfolge, 40.

160 Ibid. 52.

161 Ibid. 37. 


\subsection{Martin Luther: an anti-Semitic Hero?}

Although many theologians and politicians have inaccurately interpreted and inappropriately implemented Martin Luther's Two Kingdoms Theory, perhaps the worst example of this occurred when the Nazis gained power in Germany. A surface interpretation of the Two Kingdoms Theory reveals only the information that God made earthly governments, and that the people should be obedient to these governments. This interpretation was particularly appealing to a newly formed group within the Evangelical Church in Germany who called themselves "Deutsche Christen." The German Christians were National Socialists who wished to apply Nazi ideology to the Christian Church. They advocated eliminating the Old Testament and all elements of Judaism from the Christian religion, including people with Jewish heritage.

The 1937 Evangelical Christian Church's instructional manual, Helden und Werke der Kirche, provides insight into the German Christian's view of religion. In it, Luther is depicted as a hero who, in 1525 during the German Peasant's War, stood up against the peasants demanding their submission to the princes. Luther's Die Freiheit eines Christenmenschen, was quoted to prove Luther's standpoint: “Wir sollen nach Geboten leben, nicht in freiem, fleischlichem Mutwillen und wollen unserer erwählten und von Gott gesetzten Obrigkeit in allen zeimlichen und christlichen Sachen gehorsam sein."162 This manual avoids Luther's criticism of authority figures and gives the princes and dukes of Germany the credit for having

162 Franke, Helden und Werke der Kirche, 90. 
effected the Reformation along with Luther. The manual quotes Hitler as one of the heroes of the church, who wanted to protect the church's freedom. Hitler's contribution to the book promised to promote the mission of the church, but went on to say:

Der Staat muss aber dafür umgekehrt von den Kirchen verlangen, dass sie ihm auch ihrerseits jene Unterstützung zuteil werden lassen, deren er zu seinem Bestand bedarf. Kirchen, die dem Staate gegenüber keinerlei positiven Erfolg in diesem Sinne aufweisen können, sind für den Staat genau so wertlos, wie der Staat wertlos ist für eine Kirche, der gegenüber er unfähig ist, seine Pflichten zu erfüllen. ${ }^{163}$

The German Christians believed that Hitler had received his authority from God, and that to be disobedient to Hitler was equivalent to disobeying God. They gladly skimmed over the part of Luther's teaching from the Bible that said, "We must obey God rather than men."164 For the Nazi regime it was best that the good Lutheran people of the land only understood part of Luther's theories. They wanted the people to be completely convinced by the Nazi interpretations of Luther's teachings.

The Nazi's favorite document written by Luther was neither Von weltlicher Obrigkeit nor Die Freiheit eines Christenmenschen, even though through partial interpretation of these documents they could claim to possess God's approval and support. Their favorite document by far was Von den Juden und ihren Lügen. This work earned Luther the title of an "anti-Semitic Hero" from the Nazi perspective. In it Luther went on a tirade against the Jews and called them a plethora of derogatory

163 Franke, Helden und Werke der Kirche, 165.

164 Luther, Selections from his Writings, 387. Acts 5:29. 
names. He accused them of thievery through the charging of interest, kidnapping, and murdering children. ${ }^{165}$ He likened them to a gallstone or a bloody tumor and mocked them with the idea that they believed that when they farted, the angels danced with joy in heaven. ${ }^{166}$ His complaint in regard to how the Jewish people allegedly argued their opinions sounds much more like a criticism of his own methods than the methods of the Jews. In it he claims that when one wants to win an evil cause, then he should "schelte und lüge auf die Person" like a child whose mother has told him, "kannst du nicht gewinnen, so trag Hader ein."167 This is exactly what Luther did: he scolded and lied boldly, claiming that violent acts toward the Jews would bring honor to Christ. ${ }^{168}$ Luther's claim is absurd in light of the teachings of Christ, which are strictly non-violent and loving in nature.

The main part of Von den Juden und ihren Lügen concerns itself with interpretations of the Bible. The Jews interpreted scriptural passages that Luther believed to be prophecies about Jesus in different ways. Luther argued their interpretations at length. He compared the Jews to Catholics concerning religious customs because he was convinced that they believed in their rituals rather than putting their faith in God. His criticism of the papists, which had continually been a theme in his writings, appears repeatedly in this document as well. His opinion as

\footnotetext{
165 Luther, On the Jews and Their Lies, Pos. 1484, 2083.

166 Ibid. Pos. 2109, 2018.

167 Luther, Von den Juden und ihren Lügen, 3.

168 Ibid. 7.
} 
to which group was worse, the Catholics or the Jews, goes back and forth throughout the work. ${ }^{169}$

Luther's main complaint about the Jews at the beginning of the treatise is that they believed that they were better than non-Jews for racial reasons. Luther refuted the Jewish claim of racial superiority and argued that all people are equal. ${ }^{170}$ This theory was, of course, not useful to the Nazis, because they were trying to depict the Aryan race as superior. The claim that the Jews were racially equal to non-Jews did not fit with the goals of the National Socialist. Unfortunately the inflammatory, demeaning style with which Luther addressed all people who did not agree with him functioned well for the Nazis' goals. The last few pages of Von den Juden und ihren Lügen reads like a Nazi handbook, recommending the burning of Jewish homes, synagogues, and books and forced labor for the younger, healthier Jewish people. ${ }^{171}$ The ideas presented this inflammatory document are a senseless contradiction to the claims made earlier by Luther in Von weltlicher Obrigkeit. Luther believed that Jewish people had spread heresy because they did not believe in Jesus. Earlier he had repeatedly argued that violence has no place in the fight against heresy:

Dazu gibt es keine größere Stärkung des Glaubens und der Ketzerei, als wo man ohne Gottes Wort mit bloßer Gewalt dawider handelt. Denn man hälts da für gewiß, dass solche Gewalt die rechte Sache nicht für sich hat und gegen das Recht handle ... Sie wollen Ketzerei vertreiben, und greifen (sie) damit an, womit sie den Widerpart nur stärken, sich selbst verdächtig und jene gerechtfertigt machen. ${ }^{172}$

${ }^{169}$ Luther, On the Jews and Their Lies, Pos. 430, 2126.

170 Ibid. 51, 265.

171 Luther, Von den Juden und ihren Lügen, 7-9.

172 Luther, Von weltlicher Obrigkeit, 32-33. 
Although Luther depicted Jews in a positive light for the majority of his lifetime, the anti-Semitic rhetoric found in Von den Juden und ihren Lügen inflicted serious damage upon the Lutheran doctrines in years to come. Luther soiled his own character and that of many German Lutherans who would follow in these antiSemitic footsteps. The Nazi's followed and expanded upon Luther's anti-Semitic advice, and in doing so, they, like Luther, abandoned Biblical Christianity altogether.

\subsection{Martin Luther from Bonhoeffer's point of view}

Dietrich Bonhoeffer, who in April of 1933 was serving as a pastor at the Charlottenburg Technical University, decided to fight fire with fire. He began an article entitled Die Kirche vor der Judenfrage-The Church and the Jewish Question with two quotes by Luther. ${ }^{173}$ The first quote was from near the end of Luther's life (1546) and included the following: "Wo (die Juden) ... Christus annehmen, so wollen wir sie gern als unsere Brüder halten."174 The second quote used by Bonhoeffer, written by Luther in the year 1523, begins as follows:

Wenn die Apostel, die auch Juden waren, also hatten mit uns Heiden gehandelt, wie wir Heiden mit den Juden, es wäre nie... Christen unter den Heiden worden. Haben sie denn mit uns Heiden so

173 This article was published in der Vormarsch, 3 (1933), Heft 6, 171-176. Bonhoeffer, Berlin: 1932-1933, (English Version) 349.

${ }^{174}$ Hoffmann, Behind Valkyrie: German Resistance to Hitler, 140. 
brüderlich gehandelt, so sollen wir wiederum brüderlich mit den Juden handeln. ${ }^{175}$

This was not the image of Luther that the Nazis wanted to see. It was their goal to present Luther as an anti-Semite, and the ill-tempered man who took aim at anyone who did not agree with him worked much better for their cause. The political climate of his time made it an act of courage for Bonhoeffer to begin his article with these quotes.

But Bonhoeffer did not stop there. He went on to expound upon the political ideas of Luther in order to apply them to the times. He confirmed and supported the idea that the church should not control the state. "Zweifellos ist die reformatorische Kirche nicht dazu angehalten, dem Staat in sein spezifisch politisches Handeln direkt hineinzureden." ${ }^{176}$ His first paragraph reads like a repetition of the beginning of Luther's treatise, Von weltlicher Obrigkeit. The church should confirm that earthly governments are God-given entities, which are intended to maintain order in a godless world. The church as an organization should not attempt to influence the state. In return, the state should not try to apply its laws to the church. Just as Luther had argued in 1523 that the state should do its work and the church should attend to its duties without confusing them with each other's business, in 1933 Bonhoeffer asserted these two organizations should remain separate.

The type of separation between church and state that is practiced in the United States is different from that of the Weimar Republic (Germany) in 1933. The

175 Bonhoeffer, Berlin 1932-1933, (German Version) 349. The following changes were made in this text: hetten- hatten, heyden-Heiden, wyr-wir, bruderlich-brüderlich und widderumbwiederum.

176 Bonhoeffer, Berlin 1932-1933, (German Version), 350. 
Weimar Constitution stated in Article 137 that there was no longer a state church in Germany and that freedom of religion would be ensured. On this surface, this article seems similar to the system in the United States, but in reality, it remained quite different. Based on Article 137, the government took on the responsibility of levying taxes for the church in Germany, and Article 146 instituted religious instruction in the public schools. Article 147 established the right for minority religions to establish private schools, where their children would be instructed according to their faith. The relationship between the church and state in Germany today remains similar to that of the Weimar Republic. The website "kirchenfinanzen.de" describes it as a partnership that simultaneously works together and yet allows the church and state to remain free and independent of one another. Although Bonhoeffer understood the symbiotic relationship between the church and state, he still claimed that these two organizations should not intermingle. He did this without demanding complete change in the system. Bonhoeffer asserted that the church should serve the state and yet remain independent of party politics. ${ }^{177}$ Bonhoeffer argued that it is the duty of the church to help all people and to accept everyone who wishes to be a member in the church body. ${ }^{178}$ For Bonhoeffer, the concept that the church should serve the state was only valid if all people were to be equally served by the church.

Bonhoeffer, like Luther, believed that the state should not control the church.

177 Bonhoeffer, Berlin: 1932-1933, (English Version), 265, 366.

178 Ibid. 365-368. 
Although this concept seemed like a harmless repetition of Luther's political ideas, it was unacceptable and dangerous to the increasingly powerful National Socialist government. In April 1933, the National Socialist government passed a law requiring the boycott of all Jewish owned stores, and announced on April 7 that almost all Jewish people would immediately be forced into retirement. ${ }^{179}$ The socalled "Arierparagraph" threatened to eliminate priests and pastors who had Jewish heritage from the church. These developments were unacceptable to Bonhoeffer. He fought on in his article, Die Kirche vor der Judenfrage, claiming that the authority of the state comes originally from God through the church, and if the state denies the Christian church of its freedom to practice its beliefs, then the state has "dethroned" itself. ${ }^{180}$ According to Bonhoeffer, the consequences are as follows:

Der Staat, der die christliche Verkündigung gefährdet, verneint sich selbst. Das bedeutet eine dreifache Möglichkeit kirchlichen Handelns dem Staat gegenüber: erstens ... die an den Staat gerichtete Frage nach dem legitim staatlichen Charakter seines Handelns, d. h. die Verantwortlichmachung des Staates. Zweitens der Dienst an den Opfern des Staatshandelns. Die Kirche ist den Opfern jeder Gesellschaftsordnung in unbedingter Weise verpflichtet, auch wenn sie nicht der christlichen Gemeinde zugehören. „Tut Gutes an jedermann.“ ... Die dritte Möglichkeit besteht darin, nicht nur die Opfer unter dem Rad zu verbinden, sondern dem Rad selbst in die Speichen zu fallen. ${ }^{181}$

With these words Bonhoeffer became famous for his viewpoint concerning the "jüdische Frage." He was not ashamed to say: "wo Jude und Deutscher zusammen unter dem Wort Gottes stehen, ist Kirche."182 Unfortunately the majority

179 Hoffmann, Behind Valkyrie: German Resistance to Hitler, 137-138.

180 Ibid. 143.

181 Bonhoeffer, Berlin 1932-1933, (German Version), 353.

182 Hoffmann, Behind Valkyrie: German Resistance to Hitler, 155. 
of the members and leaders of the church were not so brave. Rather than fight against National Socialism they passed church regulations confirming the Aryan Paragraph so that baptized Christians with Jewish heritage would be forced out of the church. During this time Bonhoeffer felt himself to be alone in his convictions. There remained, however, one man with whom he could still express himself freely: Karl Barth.

\subsection{The Weaknesses of the Two Kingdoms Theory: Karl Barth's Criticism of the Evangelical Church}

Bonhoeffer had read and studied the works of the Swiss theologian, Karl Barth (1886-1964), for many years. In the spring of 1931 he was finally able to meet with Barth in person. This meeting brought about a great feeling of relief for Bonhoeffer. He described his conversation with Barth in a letter to a friend: "One breathes a real sigh of relief, and is no longer afraid of suffocating to death in the thin air."183 The mutual respect that Barth and Bonhoeffer had for each other is plain to see in their written correspondence following this meeting. Bonhoeffer not only trusted Barth with some of the deepest and most controversial questions that he had, ${ }^{184}$ but also with the decisions that would seal his fate. Bonhoeffer knew that Barth believed that any church that accepted the Aryan Paragraph was not a true

183 Quote from English source. Wüstenberg, A Theology of Life, 49.

184 Bonhoeffer, Berlin 1932-1933, (English Version), 81. 
church. Therefore he asked Barth if he should separate from the church in Germany and found a new "free" church. ${ }^{185}$ Barth's advice to Bonhoeffer was: "Wir werden nur unter den letzten sein dürfen, die das sinkende Schiff wirklich verlassen." ${ }^{186} \mathrm{He}$ believed that Christians should be politically active within the German Church as long as it remained possible.

Barth's views on the church and state were very controversial during his time. He observed a tradition in which Luther's teachings concerning the separation of church and state were taken to the extreme. The second chapter of this thesis explores Luther's claim that the Kingdom of God and the Kingdom of the World overlap inside the person who is a Christian. The ensuing Lutheran tradition took this concept as an excuse to separate the Christian faith from politics. Evangelical Christians, especially Lutherans, believed that if there happened to be a Christian here and there in the government, then the right decisions would be made without actually discussing their faith openly. They assigned the institutionalized church the task of proclaiming God's Word within the four walls of the church and claimed that social work should not be done by the church. ${ }^{187}$

Barth reacted not only against the political apathy of Evangelical Christians, but against the decades worth of German theologians and philosophers who had viewed God more as an intellectual exercise than as the creator of the universe. ${ }^{188}$

\footnotetext{
185 Bonhoeffer, Berlin 1932-1933, (English Version), 165.

186 Bonhoeffer, Berlin 1932-1933, (German Version), 126.

187 Wildemann, Existenz und Sein, 39-40.

188 More than a century's worth of theology before Barth had been dominated by the liberal theology of Schleiermacher. Schleiermacher believed that humans have a basic need for religion. This belief stands in opposition to Bonhoeffer's and Barth's belief that religion is
} 
The academic world experienced a theological earthquake in 1922 with the publishing of his book, Der Römerbrief-The Epistle to the Romans, which turned the former assumptions regarding the relevance of the existence of God up-sidedown. ${ }^{189}$ German academics had come to the conclusion that only uneducated people would put their trust in God, rather than in their own intellect and abilities. Barth destroyed this stereotype: he was a genius, well versed in philosophy, theology, and current affairs, and who also believed in an uncontrollable, omnipotent, loving God.

Barth's Der Römerbrief is a commentary on the letter that the Apostle Paul wrote to the Christian community in Rome during the first century A.D. In his book, Barth presents a new way of understanding God. He said that God "ganz anders ist, von dem der Mensch als Mensch nie etwas wissen noch haben wird und von dem ihm eben darum das Heil kommt."190 Many philosophers and theologians had asserted that a person's perspective and feelings were more important than the literal existence of God. Barth and Bonhoeffer alike were appalled by religious views that placed the focus of the church on producing a "spiritual" experience. Both Bonhoeffer and Barth saw a connection between inwardness in religion, or focusing on feelings rather than truth, and political apathy. The other popular theological position placed the focus on becoming academically educated by the

not a necessity and that God and mankind can relate without the mediation of religion, but with the mediation of Christ alone. Schleiermacher emphasized the inner feelings of dependency to prove the need for religion. Schleiermacher, Kritische Gesamtausgabe. 44; Offermann, Schleiermachers Einleitung in die Glaubenslehre, 80.

189 Metaxas, Bonhoeffer: Pastor, Martyr, Prophet, Spy, 60.

190 Barth, Der Römerbrief, 4. 
study of theological documents. Barth, who experienced no lack of academic training or of the feeling of being connected with God, still insisted that neither knowledge nor emotions can substitute for God himself.

Barth repeated the concept that God is God: he is neither an event nor an experience, but he is that, which is "völlig anders."191 Barth often employed mathematics in his descriptions of God and the world. In one such instance he assigned all worldly institutions, state, church, society and family a letter, "a b c d," and put them in brackets, which were to symbolize the world: (a b c d). Then he described God as "der Andere," or as a minus that remains outside of the brackets: $-(+a+b+c+d)$. This means that neither state nor church nor society nor family is God: he is apart from us and remains something different. Barth argues that if one wishes to overthrow a part of the human order through revolution, then he overthrows all of human order. It is similar to one person pointing at another and realizing that while the index finger points at the other person, there are always three fingers pointing back at him. In this way, if one attempts to destroy one part of human society, he will destroy them all, because they all are intertwined and consist of the same group of people. When that happens, the mathematical formula looks like this: -(-a-b-c-d). Barth noted in his conclusion that the minus representing God outside of the brackets surprisingly turns everything inside the brackets into something positive. God, as the founder of these human institutions will confirm their worth if someone tries to undermine them. ${ }^{192}$

\footnotetext{
191 Barth, Der Römerbrief, 4.

192 Barth, The Epistle to the Romans, 111-112.
} 
Barth's mathematical formula reveals other truths as well. If a person tries to present the world as faultless, then the very nature of God proves their imperfection: $-(+a+b+c+d)$. However, when a person admits that neither he nor his organization is perfect, then something positive occurs. God confirms their worth and that which was negative becomes positive: $-(-a-b-c-d)$. Barth claims that God is "ganz anders ... von dem der Mensch als Mensch nie etwas wissen noch haben wird und von dem ihm eben darum das Heil kommt."193 It is only because God stands outside of the brackets that he can bring salvation into the world.

Although Barth's theology is complicated and abstract, he lived in a manner that was down to earth. He read the paper daily and claimed that if one believes in God, then he or she must be politically involved. ${ }^{194}$ This involvement should not be unclear or subjective, carrying a tone of apology for being Christian in the political realm, but should rather have a specific direction and line determined by Christian beliefs. ${ }^{195}$ Barth viewed Christian criticism aimed at worldly organizations viewed as primarily positive. He claimed: "Der Christ hat eine natürliche Nähe zu allen Protestbewegungen in Kunst, Philosophie und Politik."196 In his opinion, problems arise when people believe that the political solutions of the past are still usable and valid.

Barth's feelings concerning breaking with the past were so strong that he avoided the word "Glaube," because he viewed it as being something internal and

\footnotetext{
193 Barth, Der Römerbrief, 4.

194 Barth, How I Changed my Mind, 12.

195 Wildemann, Existenz und Sein, 41.

196 Ibid. 47.
} 
powerless. Within the Lutheran tradition, faith had become something that led not to outward actions, but to something that hid within the church doors. Instead of "Glaube," Barth used the expression "Bewegung von Gott" to emphasize the presence of God and the human necessity to respond to his presence. ${ }^{197}$

Barth's 1938 book, Rechtfertigung und Recht-Church and State, was his response to Luther's Von weltlicher Obrigkeit and the reformation ideas about how one should view the church and state based on Luther's treatise. Although Barth agreed with Luther and other reformers that God gave the world secular authorities as a protection against dangerous behavior, he insisted that within Luther's theory a large, detrimental gap had developed with the help of the Evangelical Church. The Two Kingdoms Theory, Barth maintained, had described the separate duties of the church and state, but had not prescribed any relationship between the two organizations.

Barth repeatedly questioned whether there is a connection between Rechtfertigung und Recht—between "justification and justice."198 He described justification as the "Wirklichkeit der von Gott in Jesus Christus ein für allemal vollzogenen Rechtfertigung des Sünders allein durch den Glauben," and justice as the "Problem des menschlichen Rechtes." 199 He argued that God offers forgiveness and salvation to all people, and this realization should convince people that they must fight for human rights. He also questioned the connection between church and

197 Wildemann, Existenz und Sein, 50.

198 Barth, Church and State, 1, 9.

199 Barth, Rechtfertigung und Recht, 3 
state, as well as that between the Kingdom of God and the Kingdom of the World. ${ }^{200}$ The repetition of Reformation formulas had created and solidified a gap between the sphere of the state and that of the church. Barth considered it an impossibility to live in the past, and yet, paradoxically, he believed that in order to go forward, one must "auf die Schrift zurückgehen."201 With more than 140 scriptural references in an 86-page book, he was true to his word: he went back to the scriptures.

The conclusion that Barth reached was that the state and church are mutually responsible to each other. The state should "grant the gospel of justification a free and assured course," as well as "administer justice and protect the law."202 He noted that the authors of Römerbrief and 1. Petrus were not neutral, but rather considered it to be the duty of the state to reward good actions and punish the bad. ${ }^{203}$ Barth accused Luther and other reformers of not considering whether or not the state was actually performing its duty as described in the Bible when they asserted that citizens must perform the rendering of an oath, if demanded by the State. ${ }^{204}$ Barth admitted the possibility that the state could function contrary to its duty by rewarding the bad and punishing the good, and yet he claimed: "Der dämonisierte Staat kann das Böse wollen, aber das Gute tun

\footnotetext{
200 Barth, Church and State, 1-2.

201 Barth, Rechtfertigung und Recht ,7.

202 Barth, Church and State, 30-31.

203 Romans 13: 3: "For rulers hold no terror for those who do right, but for those who do wrong." 1 Peter 2: 13-14: "Submit yourselves for the Lord's sake to every authority instituted among men: whether the king, as the supreme authority, or to governors, who are sent by him to punish those who do wrong and to commend those who do right."

204 Barth, Church and State, 74.
} 
müssen." 205 Although Barth believed that Christians should take action to ensure that the government is functioning in a way that benefits society, he was sure that, even the most catastrophic human failures and evil deeds could be turned around by God. Barth believed that in the end, good wins out over evil.

As an example, Barth used the result of the interaction between Pilate and Jesus shortly before Jesus was crucified. The Jews, who represented the church, brought Jesus to Pilate and demanded that Jesus be crucified. Pilate, who represented the state, did not find Jesus guilty, but had him crucified in spite of his innocence. In this event, Barth considered the church and state to be unified in their collective guilt, because they had executed an innocent man. The cooperation between the religious and secular authorities in executing Jesus proved that neither the state or the church was alone in their guilt, but they showed the same capacity to be "demonic." 206 But, more importantly, the state, although it was working against justice, ended up assisting justification. In this execution of an innocent man, the predictions of the Old Testament were fulfilled and Jesus removed the sin of the world. Based on this example, Barth's shocking claim was that "(Der dämonisierte Staat) wird zähneknirschend dennoch und gerade da dienen, wo er herrschen, da bauen, wo er zerstören, da Gottes Gerechtigkeit bezeugen, wo er menschliche Ungerechtigkeit offenbaren möchte."207 Barth confidently claimed that twisted, evil regimes would ultimately fail in their attempts to wreak destruction, and that they themselves would rebuild what they had torn down.

\footnotetext{
205 Barth, Rechtfertigung und Recht, 12.

206 Barth, Church and State, 74.

207 Barth, Rechtfertigung und Recht, 18.
} 
According to Barth, the idea that an evil cause will not win out in the end was not an excuse to be politically passive. Quite the opposite, he believed that the more brutal the state proves to be, the more responsibility is laid upon the church to rectify the situation. He viewed political duties like voting, responsible decisions about the validity of laws, "Achten auf ihre Durchführung" to be important political action which can amount to "politischen Kampf." 208 He believed, and rightly so, that the people of his day had not raised enough objections against the governments of their countries. He called it a betrayal of the state to be dishonest about political opinions. Barth believed that the church's main function was to intercede with prayer for the state. But again, for Barth, this intercession is not passive. If a person prays, they must be willing to do the "entsprechende Arbeit" as well. ${ }^{209}$ He claimed that at times, it is necessary for the church to defend "den Staat gegen den Staat."210

\subsection{The Political Thought of Dietrich Bonhoeffer}

Wüstenberg clearly maps out the strong influence that Barth had on Bonhoeffer in his book, A Theology of Life, but it is possible that Barth was influenced by Bonhoeffer as well. Bonhoeffer had also interpreted and examined the Two Kingdoms Theory, which Barth criticized in 1938. In 1933, Bonhoeffer was still convinced that Luther's theory could still be positively applied to German

208 Barth, Rechtfertigung und Recht, 43.

209 Ibid. 42.

210 Ibid. 39. 
society. In his essays Was ist Kirche? and Wandlungen des Führerbegriffs, Bonhoeffer attempted to use the principles of the Two Kingdoms Theory to meet the demands of the times. He saw Luther's description of separation between the church and state as a way to stabilize the political situation in Germany. Four years later, Bonhoeffer would still defend Luther's teachings on grace, but he would begin to criticize the Two Kingdoms Theory harshly. ${ }^{211}$ Much would change in Germany from 1933 to 1937 and, in the following four years, the situation would change even more, causing Bonhoeffer to interpret the Bible anew yet again.

The unpleasant political developments in Germany during the 1930s forced Bonhoeffer to address the politics of both the church and the state as they became increasingly intermingled. Few Germans, during the winter of 1932-1933, could have known just how much control the state would assume over the church. The gap that Barth would describe five years later paralyzed the German Lutheran Church because its members believed that to support the government without question was a sign of being good Lutherans. From the beginning, Bonhoeffer saw the situation differently. Before Barth wrote Rechtfertigung und Recht, Bonhoeffer began his examination of the relationship between these two organizations in his essay, Was ist Kirche? This short essay summarizes the concepts presented in Luther's Von weltlicher Obrigkeit. Using a new, contemporary choice of words, Bonhoeffer showed how the teachings of the Reformation could protect Germany against the dangers of National Socialism. Unfortunately, the overwhelming majority of the people did not know what lay before them. Bonhoeffer was almost

211 Bonhoeffer, The Cost of Discipleship, 143. 
alone in his convictions about the dangers that could result when the state takes away the voice of the church.

Where Luther spoke about the Kingdom of God and the Kingdom of the World, Bonhoeffer referred to the church and "was sie vom Menschen her ist und was sie von Gott her ist."212 He described vividly how the church contains both spheres. "Kirche ist ein Stück Welt, verlorene, gottlose ... böse ... weil in ihr Gott zum Gespielen, zum Abgott des Menschen gemacht wird, ja ewig verlorene“, but also "Kirche ist die Durchbrechung der Welt durch das Wunder, durch die Gegenwart des Lebenschaffenden, vom Tod ins Leben rufenden Gottes,"213 Bonhoeffer considered the institutionalized church to be something boring and old-fashioned: an human construct that, on its own, is unable to move forward. It remains proudly stuck in the past. In spite of all its earthly flaws, God chooses to reach the world through the church. It testifies to God's miracles and witnesses the ideas of eternity in time, life in death, love in hate, forgiveness in sin, healing in suffering, hope in doubt. 214 Bonhoeffer emphasized the duality of the church. It is neither two separate churches nor what the church is now and what it will become. This duality is what was in the moment he was describing it and what it is in every moment.

Bonhoeffer described the church's position as being located at the boundary of human possibilities. The church speaks of God breaking through these boundaries, but cannot produce this breakthrough on its own. It remains trapped as an "Ordnung der Welt... (eine) menschliche Institution ganz innerhalb dieser

212 Bonhoeffer, Berlin 1932-1933, (German Version), 235.

213 Bonhoeffer, Berlin: 1932-1933, (German Version), 235-236.

214 Bonhoeffer, Berlin: 1932-1933, (English Version). 264. 
Grenze,"215 while simultaneously witnessing to the end of this human organization and the beginning of a new order. According to Bonhoeffer, the church borders both the heavenly kingdom and the state. ${ }^{216}$ The border itself is what defines the separate orders. The church is not God, but it looks to God and witnesses His arrival in the world. The church is also not the state, but it looks at the state and witnesses to its coming end.

Barth later described the church's limitations within the world in a similar way. He emphasized that, although it is the work of the church to announce the existence of a "heavenly state," this state is established by God and not by mankind, and the heavenly kingdom is not capable of realization here on the earth, not even in the church. ${ }^{217}$ Unlike Barth, however, Bonhoeffer believed that the separation of state and church was, in itself, a relationship. Luther had recommended, 390 years before, that the state tend to its duties and the church complete its obligations without invading each other's realms. This idea manifested itself in a passive manner: the Evangelical Church believed that it did not have to worry about politics, although they were strongly affected by political developments, due to the belief that citizens should obey governmental authorities at all times. For Bonhoeffer, the separation between church and state was not passive. He claimed that the nature of the church was political, precisely because it should remain stubbornly apolitical. He insisted that the church not allow itself to be used in party politics: "Das wäre ihr

215 Bonhoeffer, Berlin: 1932-1933, (German Version), 238.

216 Bonhoeffer, Berlin: 1932-1933, (English Version) 265.

217 Barth, Church and State, 45. 
gewisses Ende."218 Bonhoeffer spent and offered his life in the fight for the church to maintain its borders and remain apolitical in the face of the Nazi regime.

Bonhoeffer analyzed the situation from the state's point of view as well as the church's. The necessity for the state to recognize that it should not take on the work of the church is, in itself, a religious confession. When the state recognizes that it is not synonymous with God, it shows an understanding of the limits of its authority. Luther believed that the limits of governmental authority were evident in the soul. He believed the people of his time were victims of a false claim that had been made by both the church and the state: that they could exercise control over the human soul.

When Bonhoeffer was beginning his career as a theologian and pastor, the situation was completely different. Neither the church nor the state claimed to have control over the soul or even over the general social situation in which the people found themselves. Due to World War I and the economic crisis that followed in Germany, the country was left without direction or hope. Instead of the church and state leaders forcing their control on the people, it was the people who demanded that someone take control over the country, its people, their bodies, and their souls. In his lecture Der Führer und der Einzelne (1933) and the essay Wandlungen des Führerbegriffs (1933), Bonhoeffer described the danger that was growing inside the German people. Surprisingly he wrote this insightful lecture before Hitler was elected to the office of Chancellor. Two days after Hitler became Chancellor, Bonhoeffer presented a part of his lecture on the radio, but his presentation was

218 Bonhoeffer, Berlin: 1932-1933, (German Version), 239. 
interrupted in the middle. ${ }^{219}$ The lecture described a painful silence that had developed between fathers and sons in post-war Germany. There was a mutual distrust between those who had fought in World War I and those who were too young at the time to participate. The younger generation sensed the disrespect of the older generation. They knew that the older generation had experienced something horrifying, but the silence of their fathers and older brothers and the uncrossable line between them instilled in the younger generation a longing for a leader who could solve all of their problems..$^{220}$

Bonhoeffer explained that after the war, Germany was "innerlich auseinander gebrochen."221 As a result the younger generation developed a new idea of a type of authority figure that could support the unbearable weight under which they felt trapped. Bonhoeffer called the new ideal of a leader an illusion and posed the question, "Wieweit ist Führen und Geführtwerden gesund, echt, und wo wird es krankhaft, maßlos?"222 He insisted that the German people give this question careful consideration, claiming: "die Gesundheit und Geradeheit der Jugend steht hier auf dem Spiel."223 He admitted that all societies need leadership, but a change had taken place. This change was that the young people were now demanding a type of leader who stood beyond their official position. Previously one was honored because of his or her office, be it father, teacher, or statesman. But the younger generation had lost its confidence in the office and wanted a personality

219 Metaxas, Bonhoeffer: Pastor, Martyr, Prophet, Spy, 139.

220 Bonhoeffer, Berlin: 1932-1933, (English Version), 270-272.

221 Bonhoeffer, Berlin: 1932-1933, (German Version), 247.

222 Ibid. 242.

223 Ibid. 242. 
who was "vom Amt völlig gelöst."224 Bonhoeffer recognized the horrifying danger in this desire and tried to warn the German people. Few had the ability to predict what kind of nightmare would ensue from getting their wish for a "Führer."

Bonhoeffer's observations were in part political and in part religious. He challenged the people to decide if authority belonged to the leader or to his office. He feared Germany's demand for a leader who would possess the ultimate authority. He regarded this desire as a religious statement, because ultimate authority belongs not to man, but to God. He was convinced that when a person stands before God as the ultimate authority, then the person is responsible for his or her actions. "Vor (Gott) weiß sich der einzelne erst ganz als einzelner. Vor Gott ist der einzelne verantwortlich."225 Bonhoeffer believed that the opposite is true when ultimate authority is given to a human. Before the "Führer" a person is just a part of the masses, just a tool in the leader's hand. The individual is not responsible for his actions. It is not he who thinks, but his leader. If a leader, whether from his own initiative or from the initiative of the people, claims to possess ultimate authority, then the boundary between the state and church has been violated. For Bonhoeffer, this was a new problem, and yet the solution had been posed by Luther hundreds of years earlier: the state should be the state and the church should be the church.

The Nazis crossed this tangible, volatile boundary continually during the 1930s. Nazi enthusiasts, who called themselves "German Christians," gradually took

224 Bonhoeffer, Berlin: 1932-1933, (German Version) 250.

225 Ibid. 259. 
over the church with the idea of "positive" Christianity. 226 This modification of Christianity practically erased the line between the church and state. Nazi values that stood in opposition to Christian ideals crept into the churches. Rather than to uphold the Christian virtues of mercy, gentleness and kindness, the German Christians adopted the Nazis virtues of ruthlessness, strength and power. In order to make Christianity "positive" the Nazis tried to remove all Jewish elements from religion. ${ }^{227}$ The Old Testament was the first thing that had to go. Hitler began to refer to Christ as "our greatest Aryan hero,"228 in spite of the fact that Jesus was Jewish. The "German Christians" found it extremely difficult to make the New Testament "positive" as well, and many Nazi church members wanted to eliminate the New Testament as well as Jewish holy writings. ${ }^{229}$

In spite of the many changes that the German Christians had instituted in Christianity, they had not achieved unity within the church. The kind of unity that they longed to achieve was described in Helden und Werke der Kirche, in the section titled "Der Weg zur kirchlichen Einheit":

In zäher Arbeit ist durch den Führer und Volkskanzler das Reich als ein einheitlicher Staat aufgebaut worden. Die Parteien lösten sich auf, die Länder erhielten vom Führer ernannte Reichstatthalter; am 30. Januar 1934 wurden die Länderparlamente aufgelöst und alle Länderregierungen der Reichsregierung unterstellt. . . So ist es verständlich, dass der Wunsch bei dem Führer wie in vielen evangelischen Kreisen bestand, entsprechend der Beseitigung der Sonderinteressen der politischen und wirtschaftlichen Mächte auch

\footnotetext{
226 Metaxas, Bonhoeffer: Pastor, Martyr, Prophet, Spy, 151.

227 Ibid. 172.

228 Ibid. 168.

229 Ibid. 173.
} 
der Zersplitterung der evangelischen Kirche in viele Teilkirchen ein Ende zu machen. ${ }^{230}$

The unity that they demanded was directed to "alle evangelischen Christen deutscher Art."231 It was unity that excluded Catholics and those who did not display German characteristics. In this type of unity, everyone spoke German, came from the same racial background, and kept their eyes fixed on their leader, Hitler. The unity valued by Bonhoeffer differed greatly from that of the German Christians. In his version, people of every race who spoke different languages and had different cultural background were unified through the love of God. It was this aspect of the Catholic Church that had impressed him as an 18 year old in Rome: the universal nature of the church. He commented: "White, black, yellow members of religious orders - everyone was in clerical robes united under the church. It truly seems ideal."232 This "ideal" unity, which brings many different kinds of people together, differed greatly from the unity of the Germany Christians that tried to force all diversity out of the church.

The "Sonderinteressen" of whom the German Christians spoke were, in part, the churches that called themselves the bekennende Kirche-Confessing Church. Together with Karl Barth and other theologians and pastors, Bonhoeffer had written the Bethel Confession (1933), which confirms belief in both the Old and New Testaments. Bethel was an institution for handicapped people that had more than 1,600 occupants. The institution was as big as a village and had its own schools,

230 Franke, Helden und Werke der Kirche, 160.

231 Ibid. 161.

232 Metaxas, Bonhoeffer: Pastor, Martyr, Prophet, Spy, 53. 
churches, factories and stores. ${ }^{233}$ In using this name, Bonhoeffer and his colleagues pointed out that, in essence, all people are helpless and only with God's help could they find purpose in life. Whereas the Nazis viewed all weakness as repugnant, Bonhoeffer believed that strength was to be found in weakness. ${ }^{234}$ The Bethel Confession rejected the Aryan Paragraph and attested to the Biblical views that the Jews are God's chosen people to bring salvation to the world through Jesus Christ. The Bethel Confession stated that the Jewish people still have an important part to play in God's plan. ${ }^{235}$ This was a strong political statement that stood in direct opposition to Nazi ideals. Bonhoeffer continued to repeat his beliefs in this regard in spite of increasing restrictions that the Nazis would impose on him in the years that lay ahead.

The group of pastors who signed the Bethel Confession, along with their congregations, known as the Bekennende Kirche, agreed with Bonhoeffer and Barth in that "dort, wo eine Kirche den Arierparagraphen einführen würde, sie aufhört christliche Kirche zu sein."236 Bonhoeffer's opinion concerning German Christians who enacted anti-Semitic laws in their churches was that they were, in fact, not Christians. German Christians had denied church membership to Jewish people and had rejected the Old Testament and parts of the New Testament.

233 Metaxas, Bonhoeffer: Pastor, Martyr, Prophet, Spy, 184.

2341 Corinthians 1:27-29: "But God chose the foolish things of the world to shame the wise,; God chose the weak things of the world to shame the strong. He chose the lowly things of this world and the despised things-things that are not-to nullify the things that are, so that no one may boast before him."

235 Bonhoeffer, Berlin: 1932-1933, (English Version) 416-418.

236 Bonhoeffer, Berlin: 1932-1933, (German Version), 123. 
The Confessing Church in Germany, on the other hand, was opposed to the developments instigated by the "German Christians," and considered all churches in the world whose doors were open to all people, regardless of race, and believed in the scriptures, to be "confessing" Christian churches. The Nazi Regime tried to bring the Confessing Church in Germany under control through regulations that restricted freedom of speech and the freedom to assemble. ${ }^{237}$ Bonhoeffer continued fighting with the weapons he knew best: the Bible, the truth, and his God. Hitler did not believe in the Bible, the truth, or in God. Therefore he did not consider Bonhoeffer to be a threat and allowed him to work in London as a pastor from 1933 to 1935 . In London, Bonhoeffer was able to present his opinions about the growing danger in Germany to the world outside of Germany, but in 1935, he felt the need to return to his homeland. He believed, partially due to his own conscience and partially due to Barth's advice, that as a German, he belonged in Germany during the troubled times that were presenting themselves. ${ }^{238}$ Upon arriving back in Germany, Bonhoeffer led a seminary for young pastors in Zingst, a peninsula in the Baltic Sea. ${ }^{239}$

The goal of his seminary was to train men to follow God's will, in spite of anything that might happen in life. Although he did not hide his feelings about Hitler and National Socialism, it was not the focus of the seminary. The focus was prayer, God's Word, and fun. Every day the participants were given time to pray,

237 Metaxas, Bonhoeffer: Pastor, Martyr, Prophet, Spy, 206.

238 Karl Barth described the church in Germany as a house on fire and strongly encouraged Bonhoeffer to go back home on the next ship. Metaxas, Eric. Bonhoeffer: Pastor, Martyr, Prophet, Spy. S. 198. Bonhoeffer later wrote to Barth: "I think it really was the ship after next on which I came home." Bonhoeffer, The Way To Freedom: Letters, Lectures and Notes, 116.

239 Metaxas, Bonhoeffer: Pastor, Martyr, Prophet, Spy, 262. 
read the Bible, and play sports. Bonhoeffer claimed in a letter to Karl Barth that the school's daily schedule had provided the students with some much-needed support. Young men who came into the program spiritually and emotionally exhausted as well as lacking in personal direction experienced an environment where they could truly pray and read the Bible. ${ }^{240}$ Although politics were not the focus of the seminary, they did listen to the radio and were aware of the political developments in Germany. While there, it became clear to Bonhoeffer that these good Lutheran men believed that, because of their religion and the teachings of Luther, they should be willing to serve their country without question. ${ }^{241}$ Many of the men in Bonhoeffer's seminary were later called to fight for Germany and many died in battle.

During his time as seminary director in Zingst and later in Finkenwalde (1936-1937), Bonhoeffer concerned himself more than ever with the teachings of Martin Luther. He was not only concerned that Lutheran teachings had been inaccurately interpreted, but that the principles themselves that Luther had put forward in Von weltlicher Obrigkeit were wrong and misleading. His book, Nachfolge, represents his effort to correct these two problems. The book begins with a passionate defense of Luther's theory stating that we are saved through God's grace alone and not by works, which Luther had presented in his treatise, Die Freiheit eines Christenmenschen.

240 Metaxas, Bonhoeffer: Pastor, Martyr, Prophet, Spy, 271. 241 Ibid. 265. 
Bonhoeffer had noticed an inconsistency between Luther's teachings and the interpretations of the church of his day. He called the grace taught by the church "billige Gnade" and the grace in which Luther believed "teure Gnade."242 According to Bonhoeffer, cheap grace is justification of the sin, whereas costly grace is justification of the sinner. Obedience does not belong in cheap grace. Because of this, Bonhoeffer believed that it was dangerous for the church, people and the community. Cheap grace, like the Führer principle, removes personal responsibility for actions and choices. In contrast, costly grace is an encounter between a person and the living God. Through this encounter one is completely changed. The inability of the person to fulfill the law of God and God's desire to love the person anyway is perceived as an amazing revelation. Bonhoeffer claimed that costly grace is worth giving everything, even your life. ${ }^{243}$

Bonhoeffer did not, however, agree with Luther on all points. In 1937, he began to criticize the principles of the Two Kingdoms Theory, which he had defended in 1933. His ideas about an active separation of church and state, which in itself constitutes a relationship, had been developed and defended in his essays Was ist Kirche? and Wandlungen des Führerbegriffs. However, in 1937, he argued the opposite point of view in the chapters "Die Vergeltung" and "Der Feind-,Das Außerordentliche"' from Nachfolge. With these chapters he begins to erase the boundaries for which he had formerly fought.

242 Bonhoeffer, Nachfolge, 29.

243 Ibid. 30-31. 
In Von weltlicher Obrigkeit Luther had proposed a way to enact Jesus' shocking command from Matthew chapter 5: "You have heard that it was said, 'Eye for eye, and tooth for tooth.' But I tell you, do not resist an evil person. If someone strikes you on the right cheek, turn to him the other also."244 In order to follow such a commandment in a practical way, Luther differentiated between personal revenge and the duty of an office to maintain order in the world. One can and should use "the sword" in order to defend his neighbor, but revenge should not be sought and evil should be endured for one's personal self. Bonhoeffer rejected this teaching as completely alien to the teaching of Jesus. ${ }^{245}$ He claimed that it is impossible to distinguish between private and public life. Jesus' commandment is equally applicable to the father, pastor and government official. ${ }^{246}$

In Bonhoeffer's 1937 teachings, the borders between church and state seem to disappear. Bonhoeffer applied Jesus' teaching without condition to the pastor as well as the government official. Luther had claimed that "the sword" should not be used amongst Christians. ${ }^{247}$ According to Luther, retribution should be sought for one's neighbor "in the world," but within the Christian community one should not demand retribution. Bonhoeffer responded to this idea with the observation that evil exists mainly "in the world" and therefore it is in the world where one should not resist it. ${ }^{248}$ Whereas Luther believed that the Christian practice of non-violence should take place within the Christian community, Bonhoeffer insisted that a

\footnotetext{
244 Matthew 5:38-39.

245 Bonhoeffer, The Cost of Discipleship, 143.

246 Ibid. 143.

247 Luther, Selections from his Writings, 371, 373.

248 Bonhoeffer, The Cost of Discipleship, 144.
} 
Christian should be a Christian in every circumstance. Bonhoeffer believed that an individual cannot have different rules for inside and outside of the Christian community. It is the very place in which one finds evil that he should not resist it: “Je furchtbarer das Böse, desto bereitwilliger zum Leiden soll der Jünger sein. Der Böse muss Jesus in die Hände fallen."249 Bonhoeffer was not suggesting that an evil person should go unpunished for their evil deeds, but that a Christian should be willing to suffer and not return evil for evil. He believed that the evil person would then fall into Christ's hands, where evil cannot survive.

Bonhoeffer's interpretation of the fifth chapter of Matthew differed greatly from that of Luther. Bonhoeffer believed that Jesus had not laid aside retribution, He had simply introduced a new way to fight evil. According to Bonhoeffer, evil is real, dangerous, and deadly and therefore there is only one way to stop it:

Die Überwindung des Anderen erfolgt nun dadurch, dass sein Böses sich totlaufen muss, dass es nicht findet, was es sucht, nämlich Widerstand und damit neues Böses, an dem es sich um so mehr entzünden könnte. Das Böse wird darin ohnmächtig, dass es keinen Gegenstand, keinen Widerstand findet, sondern willig getragen und erlitten wird. Hier stößt das Böse auf einen Gegner, dem es nicht mehr gewachsen ist. Freilich dort, wo auch der letzte Rest von Widerstand aufgehoben ist, wo der Verzicht, Böses mit Bösem zu vergelten, restlos ist. Das Böse kann hier sein Ziel nicht erreichen, Böses zu schaffen, es bleibt allein. 250

Bonhoeffer claimed that returning good for bad reveals the true nature of the evil. He believed that "suffering willingly endured" is stronger than evil, and if someone suffers at the hands of an evil person, the evil one will be forced into Christ's

\footnotetext{
249 Bonhoeffer, Nachfolge, 137.

250 Ibid. 135-136
} 
presence. ${ }^{251}$ With this argument Bonhoeffer almost completely denies the existence of a political sphere for Christians. He says that the church "has abandoned political and national status" and in addition, the Christian is free from the "tyranny of his own ego."252 According to Bonhoeffer, unlike Luther, the behavior of a Christian should be the same within the church and out in the world: "Weil ihr in der Welt lebt und weil die Welt böse ist, darum gilt dieser Satz: ihr sollt dem Bösen nicht widerstehen."253 Bonhoeffer's interpretation highlights the contradictions found in Luther's Two Kingdoms Theory. If, as Luther claims, Christians act kindly toward each other, then there would be no need to address how to deal with evil within the Christian community. Bonhoeffer recognized that the Christian community is not perfect, meaning that Christians must be willing to suffer inside as well as outside the Christian community. He then went on to insist that the more intense the evil at hand, the more the Christian must be ready to suffer. Therefore, Bonhoeffer claims, it is where evil is to be found, most often outside the Christian community, where one is required to not resist evil.

There are only three sentences in the chapters "Die Vergeltung" and "Der Feind-Das ,Außerordentliche'” that hint that worldly governments should exist at all. In this small section, Bonhoeffer admitted that as a plan for the laws of the world, these principles would not be effective. Moreover that, as an act of love, God did indeed instill worldly governments to enforce law and order. ${ }^{254}$ Then he forges

\footnotetext{
251 Bonhoeffer, The Cost of Discipleship, 142.

252 Ibid. 141-142.

253 Bonhoeffer, Nachfolge, 138.

254 Ibid. 144.
} 
on, further blurring the line between church and state. In Von weltlicher Obrigkeit, Luther had dealt with Jesus' command not to resist evil, but he did not examine the following commands. Bonhoeffer believed that what Jesus said next could not be separated from His command of non-violence: "Liebet eure Feinde; segnet, die euch fluchen; tut wohl denen, die euch hassen."255 Bonhoeffer defined the potential enemy as both the church and the state. During Jesus' lifetime, His enemies, who were, in turn, the enemies of His followers, were religious people as well as the representatives of the Roman government. One should have the same attitude toward enemies from both organizations: an attitude of unqualified love. Bonhoeffer claimed that the command to love one's enemy was not new, but already existed before Christ's time in the Old Testament. ${ }^{256}$

Bonhoeffer repeated the concept that a division between the private person and the official should not exist. Within both roles one should "bless, do good, and pray for your enemies without reserve and without respect of persons." ${ }^{257}$ In the chapter “Der Feind - Das ,Außerordentliche,'“ Bonhoeffer comments that law without love separates people through judgment, whereas the law of God would be perfectly fulfilled when a person loves and prays for his enemy. This prayer brings the enemy and the intercessor together "unter dem Kreuz Jesu Christi."258 Bonhoeffer believed that, when, through prayer, a person recognizes that both he and his enemy stand as sinners before God, then God's desire to justify them both

255 Bonhoeffer, Nachfolge, 140.

256 See appendix E.

257 Bonhoeffer, The Cost of Discipleship, 148.

258 Bonhoeffer, Nachfolge, 147. 
becomes evident. The ability to love one's enemy is characterized as unnatural or "extraordinary." 259 Love is neither partisan nor political. It is not the love that was propagated by the Evangelical Church: a love for country, friends and family. Such love is diluted and "natural." Bonhoeffer claimed: "Nicht innerhalb der natürlichen Gegebenheiten geschieht das Christliche, sondern in dem Über-sie-hinaus-treten."260 In order to love one's enemies, one must not think about what the enemy has done, but think about what Jesus did. ${ }^{261}$

The disappearance of boundaries that Bonhoeffer described in Nachfolge is, however, one-sided. He erased the boundary from the side of the church, but claimed that the line still exists, but it is only drawn by the world. Bonhoeffer introduced the idea that the church must remain without borders, because its job is to welcome all people. "(W)here the church establishes its boundaries itself, legalistically and beforehand... (it) betrays its commission to call men to salvation."262 The boundaries should only be established where the world has refused the invitation of the church. According to Bonhoeffer, the church must recognize the boundaries set by the world and yet still maintain an open invitation. ${ }^{263}$ Through the disappearance of the boundaries from the side of the church, Bonhoeffer saw the church as "a wider place, a wider body"264 than that described by Luther in Von weltlicher Obrigkeit.

\footnotetext{
259 Bonhoeffer, Nachfolge, 147.

260 Ibid. 147

261 Ibid. 150.

262 Bonhoeffer, The Way To Freedom: Letters, Lectures and Notes, 83.

263 Ibid. 84.

264 Ibid. 43.
} 
Like Barth, Bonhoeffer had begun to criticize Luther. Barth criticized the Evangelical Church's implementation of the Two Kingdoms Theory because it did not recommend that the church be politically active. In Rechtfertigung und Recht Barth explained quite clearly that he believed that the church should be politically involved. The opposite point of view is to be found in Nachfolge, where Bonhoeffer criticizes the Two Kingdoms Theory for recommending too much political involvement. He claims that it is not only possible, but preferable and more effective to follow Jesus' command not to withstand evil, but to allow it to run itself to death due to a lack of opposition. Ironically, these two men's actions showed the exact opposite of what they had been preaching. Barth defended soldiers who fought against Hitler and called them martyrs, but he himself did not fight in the war. ${ }^{265}$ In 1940 Bonhoeffer, who had insisted that one never fight against evil, decided to become part of a plot to kill Hitler. With this decision, Bonhoeffer fulfilled his own prediction: he fell into the spokes.

265 Metaxas, Bonhoeffer: Pastor, Martyr, Prophet, Spy, 326. 


\section{Reinventing the Two Kingdoms Theory: Bonhoeffer's Religionless Christianity}

The Two Kingdoms Theory and Religionless Christianity have the same basic goal: distinguishing God from humans. The middle section of the treatise, Von weltlicher Obrigkeit, is an attempt to show the limits of human power. In this section Luther repeats that no one has control over another human's soul, including representatives from both the church and the state. ${ }^{266}$ Luther fought against the claims of the Pope and the bishops of his day to emphasize that there are limits to human capabilities, and argued that God alone is almighty.

Bonhoeffer's struggle was more subtle. The Evangelical Church of the early $20^{\text {th }}$ century did not claim that the church leaders had direct control over the soul, but rather that the religion itself, the rituals, formulas, and faith in a collective sense were the only way to create a bond between mankind and God. The confusion between God and man was still present in Bonhoeffer's time, although it was more difficult to identify in a concrete manner. Rather than saying, "It is my decision if you go to heaven or hell," like the Pope and bishops had said in Luther's day, the church said, "If you do not do what I do, you will go to hell." Although they did not claim to have power over the soul, they determined what one must do or believe in order to go to heaven.

Bonhoeffer tried to distinguish religion from God. Martin Luther had done this almost 400 years earlier, yet Bonhoeffer felt the need to do it once again. The

266 Luther, Selections from his Writings, Secular Authority, 382-392. 
reason was that society had undergone great changes and the idols had changed their appearance. The obvious idols of the time, Hitler and National Socialism, were easy to identify. But the other idol, religion used as a method to control others, was more difficult to identify and therefore more difficult to avoid. ${ }^{267}$

\subsection{The Kingdom of God: Not a Synonym for Religion}

It is possible to discuss political events and the political activities of Luther, Barth, and Bonhoeffer without mentioning the Kingdom of God, but to do so would be to ignore their primary motives in addressing politics. All three were motivated by a deep belief in God and His Kingdom. Their desire to establish human rights through the government came as a result of their belief in the heavenly kingdom. Luther, Bonhoeffer, and Barth had God's grace and Christ's desire to justify all people as an example set before them. According to Barth, Christians do not have to wait until after death, but here and now have "Bürgerrecht in der himmlischen Stadt, die mehr real und fest ist, als alle anderen Städte."268 He describes this place as the only real state; not "an imaginary one, but ... the only one that truly exists."269 Barth perceived two effects that come as a result from recognizing the reality of the other sphere known as the Kingdom of God. The first effect is separation. The

\footnotetext{
267 Bonhoeffer, Berlin: 1932-1933, (English version),262-263; Bonhoeffer, Letters and Papers from Prison, 344. 268 Barth, Rechtfertigung und Recht, 22.

269 Barth, Church and State, 38.
} 
Christian will be separated from this world because he knows that the perfection of heaven cannot be found or realized in either the state or the church on earth. ${ }^{270}$ The second effect is a renewed and deepened bond with the world and its inhabitants. Because people who believe in God's Kingdom see a heavenly city without hunger, poverty, pain and hatred, they want to eliminate hunger, poverty, pain and hatred from the secular world. The church sees its future and its hope in "der himmlischen Stadt."271 From the focus on the coming age, those who believe gain the strength to "proclaim here and now, the justification of the sinner through the blood of the Lamb."272 Thus, the connection with the heavenly kingdom that is to come, Barth argues, enriches and strengthens the believer's connection with the present world.

Both Barth and Bonhoeffer presented the paradox that an understanding of the Kingdom of God causes both a separation from the world, and a renewed, deeper bond with it. Muscles in the human body provide an analogous situation. The only way a muscle can grow stronger is for it to tear. When a muscle is worked, the tiny fissures that are created heal into stronger connections, building muscle mass. The muscle must continue to create these little fissures, or separations, in order to maintain or improve its condition. If this does not occur, the muscle will atrophy. In this same way, a Christian must be willing to tear away from the world in order to build a healthier, stronger connection with it.

The unwillingness to let go of certain worldly objects, experiences, or habits can inhibit the opportunity for growth. This type of unhealthy connection with the

270 Barth, Church and State, 39, 45.

271 Barth, Rechtfertigung und Recht, 23, 26.

272 Ibid. 41. 
world can occur within the church in the form of religion. ${ }^{273}$ Bonhoeffer witnessed "German Christians" and "Confessing Christians" alike holding tight to their religion while delivering Jews into the hands of the Nazis. These people wanted to maintain their bonds with their church and country, even if that meant the sacrifice of their neighbor. Bonhoeffer spent his life in opposition to religion that functioned in this way. He was prepared to sever his relationship with his church and country in order to follow Jesus. For Bonhoeffer "Nachfolge-discipleship" meant obedience to the living, present Son of God. ${ }^{274}$ Bonhoeffer believed that "der Ruf in die Nachfolge . .. Bindung an die Person Jesu Christi allein (ist)."275 The disciple's attachment to the person of Jesus then draws him back into the world. Just as Jesus ate with "sinners" and welcomed children into His arms, so the disciple is called into fellowship with non-religious people. ${ }^{276}$ Bonhoeffer emphasized the non-programmatic nature of Christianity:

Eine Idee von Christus, ein Lehrsystem, eine allgemeine religiöse Erkenntnis von der Gnade oder Sündenvergebung macht Nachfolge nicht notwendig, ja schließt sie in Wahrheit aus, ist der Nachfolge feindlich. 277

Religion is made of plans, programs, and content. Therefore, according to Bonhoeffer, religion is not discipleship. The religion of his time in Germany claimed

\footnotetext{
273 The word "church" can refer to a building, a group of people, a religious service, or an organization. Barth and Bonhoeffer often use the word "church" to describe people who are obedient to God. In this sense, it does not indicate membership to a certain religious organization, but rather the unseen belief within a person which leads to visible actions confirming God's will in the world. The visible and invisible aspects of a Christian are described by Bonhoeffer in The Cost of Discipleship.

274 Bonhoeffer, The Cost of Discipleship, 57-59.

275 Bonhoeffer, Nachfolge, 47.

276 Bonhoeffer, Letters and Papers from Prison, 362.

277 Bonhoeffer, Nachfolge, 47.
} 
that he should be obedient to Hitler. Because of his connection with Jesus, instead of being obedient to Hitler, Bonhoeffer helped Jews escape from Germany.

The Gestapo arrested Bonhoeffer in the spring of 1943, due to his activities with the Wehrmacht.278 During Bonhoeffer's time in a prison cell at Tegel (194344), he began to concern himself with the question of Religionless Christianity. He often mentioned Barth as the first person to criticize the essence of religion. ${ }^{279}$ Of course Bonhoeffer was aware that many people, including the reformers, had criticized religion before Barth, but Bonhoeffer believed that Barth's criticism went deeper than that of the reformers. Bonhoeffer considered the criticism expressed by Luther and Calvin to be only a partial critique. Their intent was to reconstruct or change a part of the system, whereas Barth's critique encompassed the whole concept of religion. The question was not "how do we repair the system?" but "should we have the system at all? Is the religion necessary to have a relationship with Jesus?" These questions posed by Barth sparked the concept of Religionless Christianity in Bonhoeffer.

278 Metaxas, Bonhoeffer: Pastor, Martyr, Prophet, Spy, 437.

279 Bonhoeffer, Letters and Papers from Prison, 280, 286, 328. 


\subsection{The Enlightenment of the World: Is Religion Still Necessary?}

During Luther's time, there was no question as to whether or not religion should exist. The majority of people were religious, and Luther did not foresee a change in the existence of the faith as such. People needed God, and the church gave them the feeling that they had a connection with Him. However, in Luther's text there is a hint to be found concerning the increasing awareness of the people: "der einfache Mann wird verständig." ${ }^{280}$ In Luther's day, the people felt the need for religion because they had so little control over their lives. They had to pray, because otherwise they could not solve their problems. In the years that followed, especially during the Enlightenment, the world's maturity in terms of increasing knowledge about science, the natural world, and physical and mental health seemed to remove the need for God from many people's lives.

Bonhoeffer noted that God had been used as a "Lückenbüßer unserer unvollkommenen Erkenntnis." ${ }^{281}$ Jesus was to be found where knowledge failed. With the enlightenment of the world, the frontiers of knowledge were pushed further and further back, leaving less and less room for Jesus. ${ }^{282}$ In religious terms, Jesus stood on the border of human knowledge. As this knowledge expanded, Christ was pushed further and further away. The world had its own power. It did not need God's power any longer. Bonhoeffer considered it false teaching to explain Jesus as a stop-gap. For him, Jesus was the Lord of the world: over, under, through and in

\footnotetext{
280 Luther, Von weltlicher Obrigkeit, 34.

281 Bonhoeffer, Widerstand und Ergebung, 163.

282 Bonhoeffer, Letters and Papers from Prison, 311.
} 
everything. ${ }^{283}$ The fact that religious people wanted to search out other people's weaknesses to find a place for God, disgusted Bonhoeffer. He claimed that, whereas he felt comfortable talking about God with non-religious people, he did not feel comfortable discussing God with religious people.

Während ich mich den Religiösen gegenüber oft scheue, den Namen Gottes zu nennen, - weil er mir hier irgendwie falsch zu klingen scheint und ich mir selbst etwas unehrlich vorkomme, - kann ich den Religionslosen gegenüber gelegentlich ganz ruhig und wie selbstverständlich Gott nennen. Die Religösen sprechen von Gott, wenn menschliche Erkenntnis (manchmal schon aus Denkfaulheit) zu Ende ist ... ich möchte von Gott nicht an den Grenzen, sondern in der Mitte, nicht in den Schwächen, sondern in der Kraft, nicht also bei Tod und Schuld, sondern im Leben und im Guten des Menschen sprechen. ${ }^{284}$

Bonhoeffer believed that religion, when given more importance than knowing Christ personally, limited one's personal abilities by presenting a false, watered-down version of both human and Godly capabilities. Bonhoeffer felt that non-religious people had not tried to trap God by their dogma, and were often more honest than religious people.

\subsection{Violence in Religion}

In order to distinguish the church as an organization from God and confirm that neither the church nor the state can take the place of God, Luther said that no

\footnotetext{
283 Ibid. 312.

284 Bonhoeffer, Widerstand und Ergebung, 142.
} 
one can force anyone else "so oder so zu glauben." ${ }^{285}$ At that time it was common practice to insist that people believe certain religious ideas in order to exercise political control over them. Although Luther claimed, "das Herz ... sie ja nicht zwingen (können)," he admitted that people can be driven to false confessions through force. "Sie treiben damit die schwachen Gewissen mit Gewalt dazu, zu lügen, zu verleugnen, und anders zu reden, als sie es im Herzen meinen."286 Luther emphasized not only that faith is "ein freies Werk" to which no one can be forced, but that no one can see, know, judge, condemn, or change the heart of another person. 287

Similarly, Bonhoeffer expressed the concern that the religion of the $20^{\text {th }}$ century Evangelical Church still used violent methods to convert people to Christianity, even though the violence was not as obvious as it was in Luther's time. He believed that this new violence came from the fact that religious people wanted to use Jesus as a stop-gap, meaning that Christ was used as a filler to cover up for human weaknesses and failings. Bonhoeffer believed that religious people were spying out other people's weakness to convince them of their need for God. "Menschliche Kräfte (müssen) versagen" in order for religious people to speak about religion. ${ }^{288}$ Because religious people set about the task of proving other people's weaknesses in order to find a place for God, Bonhoeffer began to question, "Sollen wir ein paar Unglückliche in ihrer schwachen Stunde überfallen und sie sozusagen

285 Luther, Von weltlicher Obrigkeit, 27.

286 Ibid. 28.

287 Ibid. 27.

288 Bonhoeffer, Widerstand und Ergebung, 142. 
religiös vergewaltigen?"289 Bonhoeffer's shocking choice of the word "vergewaltigen" shows just how uncomfortable he was with the religion of his day. He felt that capitalizing on a person's weaknesses in order to force religion on them, was comparable to a physical assault.

Bonhoeffer continued to criticize those in leadership of Christian churches: “Die Kammerdienergeheimnisse—um es grob zu sagen—d.h. also der Bereiche des Intimen (vom Gebet bis zur Sexualität)—wurden das Jagdgebiet der modernen Seelsorger."290 Bonhoeffer found the idea repulsive that pastors would intrude uninvited into the personal lives of those they are called to serve. He did not want to use "religious blackmail" on others and believed: "Es ist gar nicht nötig, herumzuspionieren."291 Such behavior, Bonhoeffer insisted, was neither helpful in ministering to Christians nor helpful in converting non-believers to Christianity.

Although Bonhoeffer apologized for using such strong language, he wanted to make it clear to what extent religion can be misused in the name of God..$^{292}$ He saw that God was being driven out of the public sphere and the church sought to defend an "innerlichen, privaten" sphere for God. ${ }^{293}$ Religious people thought that God's

\footnotetext{
289 Bonhoeffer, Widerstand und Ergebung, 140.

290 Ibid. 185.

291 Ibid. 185-186.

292 These controversial ideas that Bonhoeffer expressed were written in private correspondence to his best friend, Eberhardt Bethge. Bonhoeffer believed that confession was an important part of Luther's teachings. One should confess their weaknesses, doubts and sins to each other. Like Luther, Bonhoeffer believed that a priest should not fulfill this role for an entire community, but that each person should decide for him or her self, to whom he or she would confess. Bethge was the person that Bonhoeffer had chosen as his confessor. Ironically, we are only able to read about Bonhoeffer's defense of the private life of others because his private correspondence was made public. Metaxas, Bonhoeffer: Pastor, Martyr, Prophet, Spy. 273.

293 Bonhoeffer, Widerstand und Ergebung, 185.
} 
presumed move from the public to the private sphere gave them the right to enter the private sphere uninvited. Bonhoeffer was strongly opposed to such rude behavior. He knew that in the past, people had been dependent on religion and believed that religious people wanted to return to this past period in history. Bonhoeffer referred to this as "willkürlichen Verzicht auf innere Redlichkeit." ${ }^{294} \mathrm{He}$ was convinced that this is not the will of God. God made mankind intelligent: God does not need for people to pretend that they are ignorant. If a person's intelligence leads them to reject God, then He allows Himself to be "pushed out of the world on to the cross-aus der Welt herausdrängen ans Kreuz." ${ }^{295}$ God does not force Himself onto people. The tendency of religious people to do so was a proof to Bonhoeffer that religion and Christianity do not belong together.

\subsection{Defining Religion}

Augustine defined religion as love for God, self and other people and the effort to bring people to God. ${ }^{296}$ He saw the good side of religion as a connection between God and mankind that comes out of a free choice. He also noted that it is human nature to oppress one another. ${ }^{297}$ Due to this tendency, religion is often used inappropriately. Instead of creating a bond between God and mankind, people use

294 Bonhoeffer, Widerstand und Ergebung, 192.

295 Ibid. 192.

296 Augustine, The City of God, Book X, Ch. 3.

297 Ibid. Book XVIII, Ch. 2. 
religion as a way to control other people. Martin Luther expressed the idea that "although (God) is present in all creatures, and I might find him in stone, in fire, in water, or even in a rope ... yet he does not wish that I seek him there apart from the Word, and cast myself into the fire or the water, or hang myself on the rope."298 Long before Bonhoeffer had formulated theories about Religionless Christianity, Luther had pointed out that, although one may find God in religion, one should not tie himself or herself up with religion. The negative sense of religion for Luther was "Werke—works," whereas the positive sense was "Glaube—faith" and "Gnade— grace." Works also belong to the Kingdom of the World. Luther's first attempt to create a bond with God was as a monk in a cloister. Bonhoeffer said that when Luther "ins Kloster ging, hatte er alles zurückgelassen, nur sich selbst, sein frommes Ich, nicht."299 It was there that Luther realized that even the monastery is a part of the world. ${ }^{300}$ Luther was made aware that to leave behind the only thing that he had hung onto, his "frommes Ich," he would have to give his life to God, not to the monastery. Luther had learned that neither religion nor religious people are a substitute for God Himself.

Luther did not, however, question the continued existence of religion. Bonhoeffer, using Luther's basic principles, struck out on a new path. He began to question, if religion is not God, do we need it at all? With this question, he introduced a clarified understanding of what religion is and what it can be. Bonhoeffer still believed that the love for God, self and others that Augustine had

298 Luther, Luther's Works, Volume 36, 342.

299 Bonhoeffer, Nachfolge, 34.

300 Bonhoeffer, The Cost of Discipleship, 48. 
presented was necessary in life. Luther foreshadowed Bonhoeffer's negative definition of religion when he said that no one can force another "so oder so zu glauben."301 Bonhoeffer's reformulation of Luther's statement defined religion as "die zeitbedingten Voraussetzungen der Metaphysik, der Innerlichkeit etc."302 Luther had learned, through the church, that the church is not God. Bonhoeffer learned, through complicated religious theories, that religious theories are not God. The presuppositions of metaphysics, or how one thinks that people should perceive the world, had changed significantly for Bonhoeffer during the course of his lifetime. Bonhoeffer's negative definition of religion contained the idea that all people should understand reality in the same fashion.

For Bonhoeffer, to insist that all people perceive reality in the same way was to deny Jesus. Bonhoeffer had experienced the necessity to stay flexible in his convictions in order to have the ability to follow the call of Jesus. In his book Nachfolge (1937), he wrote a chapter entitled "Die Wahrhaftigkeit"—“Truthfulness," in which he gave no excuse for lying under any circumstance. He claimed that one must always speak the truth. To do differently would create a divide between the person and their Creator. "Es gibt keine Wahrheit Jesus gegenüber ohne Wahrheit den Menschen gegenüber. Die Lüge zerstört die Gemeinschaft." ${ }^{303}$ Three years later Bonhoeffer began to lie on a regular basis: In order to fight against the increasingly dangerous Nazi regime, he had to pretend to be loyal to the Third Reich. ${ }^{304} \mathrm{He}$

\footnotetext{
301 Luther, Von weltlicher Obrigkeit, 27.

302 Bonhoeffer, Widerstand und Ergebung, 141.

303 Bonhoeffer, Nachfolge, 133.

304 Metaxas, Bonhoeffer: Pastor, Martyr, Prophet, Spy, 370.
} 
joined the Abwehr and began to practice deception regularly in order to obtain the permission to travel as a representative of Hitler. His lies to his own government afforded him the opportunity to secure support from abroad for the German resistance against Hitler. ${ }^{305}$

In order to be useful to the Abwehr, Bonhoeffer had to swear loyalty to the Third Reich. His lies were convincing enough that many of his former colleagues and friends considered him to be a traitor to the Christian faith. ${ }^{306}$ While he was risking his life to save Jewish lives through "Operation 7" and prepare an alternative government to take over after the planned assassination of Hitler, he was being harshly judged by others for his perceived cooperation with the Reich. ${ }^{307}$ "Untruthfulness destroys fellowship," he had said. Did he want to destroy fellowship or save it? Did he still believe what he had written in Nachfolge? During this period of his life he began to write Ethik. This book emphasizes Jesus' saying from Matthew 7:1: "Judge not, that ye be not judged." ${ }^{308}$ He claimed that the will of God is made known in action and that "in unaufhebbaren Gegensatz zum Tun steht das Richten." ${ }^{309}$ His opinions had changed significantly since he had written Nachfolge. In 1944 he admitted that he could see "die Gefahr" of that book, although he still stood by it. ${ }^{310}$

\footnotetext{
305 Metaxas, Bonhoeffer: Pastor, Martyr, Prophet, Spy, 376.

306 Ibid. 376.

307 Ibid. 364-376.

308 Bonhoeffer, Ethics, 34.

309 Bonhoeffer, Ethik, 330.

310 Bonhoeffer, Widerstand und Ergebung, 195.
} 
Bonhoeffer viewed institutionalized religion as a system, a program, or a certain formulation of faith, which of its own accord is unable to change its worldview. For him institutionalized religion stood in direct opposition to the essence of discipleship, which is a readiness to follow the God Who is active in the world at a moment's notice. Religion fights against personal, societal and world development, whereas God is the one who instigates the development of the person, the society, and the world ${ }^{311}$ Like a mother bird pushing its baby out of the nest so that it can learn to fly, God forces us to recognize that we have to live in this world "etsi dues non daretur" (without the existence of God). ${ }^{312}$ By recognizing our own abilities, we recognize our Creator. What religion finds threatening, God finds necessary: “Gott selbst zwingt uns zu dieser Erkenntnis." ${ }^{13}$ Like Luther’s Two Kingdoms Theory, Bonhoeffer's Religionless Christianity insisted that religion is not God, but that Jesus is "wirklich Herr der Welt."314

\subsection{The "Diesseitigkeit" of the Kingdom of God}

For Bonhoeffer and Luther the idea of the Kingdom of God instigated less thought about a heavenly place, which one will only experience and understand after death, and more about this world and how one should behave in the here and

\footnotetext{
311 Bonhoeffer, Letters and Papers from Prison, 327, 360.

312 Ibid. 360.

313 Bonhoeffer, Widerstand und Ergebung, 192.

313 Bonhoeffer, Letters and Papers from Prison, 141.

314 Bonhoeffer, Widerstand und Ergebung, 141.
} 
now. Bonhoeffer insisted that one must drink fully of the "earthly cup" in order to be like Christ: "Das Diesseits darf nicht vorzeitig aufgehoben werden." ${ }^{315}$ An explanation from Augustine is helpful in understanding how the Kingdom of God can be understood as an earthly matter. Augustine emphasized that the City of God is made of "living stones." The very people who believe in God are His city and His temple. ${ }^{316}$ Because it is the duty of a Christian to proclaim justification (Barth) and to draw no boundary lines, but rather to welcome all people freely to fellowship with Christ (Bonhoeffer), serving the Kingdom of God is a worldly task. It is, purely and simply, love for one's neighbor and respect for Christ, whom the Bible described as the corner stone. ${ }^{317}$

Jesus said, "Seek first his kingdom and his righteousness, and all these things will be given to you as well." 318 It would be easy to picture the Kingdom of God as a thing or a place but, according to Augustine, who drew his ideas from the Bible, ${ }^{319}$ the Kingdom of God is the people themselves. Because this kingdom consists of people, Jesus' advice to "seek first his kingdom" supports Bonhoeffer's claim, “dass die Menschen uns wichtiger im Leben sind als alles andere."320 Bonhoeffer considered the willingness to help each other as the essence of following Jesus. Just as Jesus was ready to love, heal, and take on the troubles and sins of the world and

\footnotetext{
315 Bonhoeffer, Widerstand und Ergebung, 180.

${ }^{316}$ Augustine, The City of God, Book VIII, Ch. 24. Book VII, Ch. 9.

317 Acts 4:10-12.

318 Matthew 6:33.

3191 Peter 2:5-6: "you also, like living stones are being built into a spiritual house to be a holy priesthood, offering spiritual sacrifices acceptable to God through Jesus Christ. For in Scripture it says: 'See, I lay a stone in Zion, a chosen and precious cornerstone, and the one who trusts in him will never be put to shame.'" (Isaiah 28:16).

320 Bonhoeffer, Widerstand und Ergebung, 207.
} 
die for mankind, so should the disciple be available to help other people. Bonhoeffer was aware that seeking the Kingdom of God can have pleasant and unpleasant effects, but it is always worth the effort. When one takes up the cross of Jesus, ${ }^{321}$ they must be willing to fully partake in the lives of the people around them, for Bonhoeffer claims that "Jesus nur ,für andere da' ist."322 The disciple, like Jesus, suffers with others, but also rejoices with them. "Es gibt aber kaum ein beglückenderes Gefühl als zu spüren, dass man für andere Menschen etwas sein kann." 323 Bonhoeffer was convinced that our relationship with God is not a religious relationship, but rather "ein neues Leben im ,Dasein-für-andere."”324 The tasks that have to do with the Kingdom of God are not "unerreichbar." It is, according to Bonhoeffer, the neighbor within reach in any given situation who represents God's Kingdom..$^{325}$

Bonhoeffer introduced a metaphor for religion: "(es ist) nur ein Gewand des Christentums," and that this garment "zu verschiedenen Zeiten sehr verschieden (aussah)." 326 When a person clothes himself with religion for the purpose of appearing pure, it is then that he appears to be disguised and dishonest. According to Bonhoeffer, religion contains in itself a feigned quality. One must have the ability to remove the garment of religion in order to be authentic and honest. That does not mean that Bonhoeffer was recommending a lifestyle lacking in moral

\footnotetext{
321 Bonhoeffer, The Cost of Discipleship, 88.

322 Bonhoeffer, Widerstand und Ergebung, 204.

323 Ibid. 206.

324 Ibid. 204.

325 Ibid. 204.

326 Ibid. 140-141.
} 
convictions. He believed that providing a good example was very important and that "Dasein-für-andere" involved Christian virtues such as purity, trust, loyalty, patience, discipline, and humility. ${ }^{327}$ These virtues, however, must truly be demonstrated with actions and not be used as an excuse to judge other people.

Bonhoeffer was interested in knowing what it would look like if one were to remove the garment of religion from Christianity. For Bonhoeffer, being a Christian brings a person into the state of being fully human. According to him, the 'heart' in the Biblical sense is not the inner life, but "der ganze Mensch" in relation to God." 328 Because the heart is the whole person, and because being a Christian is nothing more or less than being fully human in the presence of God, removing the garment of religion should not be a threatening prospect. It should be a simple act of honesty.

Bonhoeffer believed that Christians should not ask: "Was muss ich glauben?"329 Bonhoeffer considered this to be an inappropriate question that leads to hiding behind the church. To ask this question is to pull the garment of religion close and to evade the honest question as to "was man selbst eigentlich glaubt." 330 For Bonhoeffer, as for Luther, faith is not a matter to be forced upon someone. Concerning the church, Bonhoeffer answered the question for himself as to what he really believed: "Die Kirche ist nur die Kirche, wenn sie für andere da ist." 331

\footnotetext{
327 Bonhoeffer, Widerstand und Ergebung, 205.

328 Ibid. 186.

329 Ibid. 204-205.

330 Ibid. 204-205.

331 Ibid. 205.
} 
Bonhoeffer hence changed the focus from a fixed confession to an active willingness to serve and help other people.

Bonhoeffer claimed that Luther was a "diesseitiger" Christian. ${ }^{332}$ Luther's focus on this world was evident in his lifestyle as well as in the Two Kingdoms Theory. In Von weltlicher Obrigkeit he distinguished between the Kingdom of God and the world not to provide the opportunity to discuss unrealistic, other-worldly circumstances, but rather to give concrete, accessible advice for the here and now. According to Luther, earthly governments are "durch Gottes Willen und Ordnungen in der Welt" and Christians should support them. ${ }^{333}$ His advice to authority figures was notably "diesseitig." The existence of the Kingdom of God should lead those with power to serve the people selflessly. ${ }^{334}$ In this point, Bonhoeffer agrees with Luther: it is through selfless service in this world that the Kingdom of God becomes evident.

Although Luther and Bonhoeffer came to the same conclusions in regards to Christian service, their cultural surroundings were very different. Bonhoeffer observed hateful, racist behavior in people who referred to themselves as Christians. At the same time, there were other people who did not claim to be Christians who lived according to the teachings of Jesus. One example, with whom Bonhoeffer was fascinated, was Mahatma Gandhi. ${ }^{335}$ Gandhi and his followers lived a lifestyle similar to that described in Von weltlicher Obrigkeit. They lived in peace

332 Bonhoeffer, Widerstand und Ergebung, 195.

333 Luther, Von weltlicher Obrigkeit, 7.

334 Ibid. 38.

335 Metaxas, Bonhoeffer: Pastor, Martyr, Prophet, Spy, 248. 
with each other without claiming personal property. Barth called Gandhi a "friend of God" and was enthusiastic that Bonhoeffer wanted to learn from him. ${ }^{336}$ Just as Luther had called Jews who lived before Christ, "Christians,"337 Barth and Bonhoeffer felt a brotherly love for non-Christians who lived in harmony with Jesus' teachings. The name with which they were labeled was not as important as the way in which they lived their lives. ${ }^{338}$

According to Metaxas, Gandhi tried to live according to the principles presented in Jesus' Sermon on the Mount. ${ }^{339}$ Bonhoeffer was just as caught up with this sermon as was Gandhi. The set of values presented in the Sermon on the Mount, which Bonhoeffer considered to be of key importance, were exactly those that the Nazis had rejected: gentleness, mercy, righteousness and a pure heart. ${ }^{340}$ The Nazis considered these virtues to be completely foreign and could not understand how such a sermon could be a threat to them. These were, however, the weapons that Bonhoeffer used against the Nazis. They did not fear these virtues even though these principles gave Bonhoeffer the courage to question the state on a regular basis. His strength from the beginning to the end came from the belief that God was by his side. The concept of the Kingdom of God being here on earth, as well as in heaven to come, was not abstract for Bonhoeffer. It was his permanent home, which

\footnotetext{
336 Bonhoeffer, The Way To Freedom: Letters, Lectures and Notes, 119.

337 Luther, Selections from his Writings, Secular Authority, 376.

3381 John 2:4-6: 'The man who says, 'I know (Jesus),' but does not do what he commands is a liar, and the truth is not in him. But if anyone obeys his word, God's love is truly made complete in him. This is how we know we are in him: Whoever claims to live in him must walk as Jesus did."

339 Metaxas, Bonhoeffer: Pastor, Martyr, Prophet, Spy, 248.

340 See Appendix F.
} 
could not be taken away from him, consisting of the people whom he would help at all costs.

That the Kingdom of God consists of people who live according to God's Word led Luther and Bonhoeffer to a lifestyle that was simultaneously "diesseitig" and "jenseitig." They believed that life here on earth as well as life in heaven is to be enjoyed in large part due to the people around them. Bonhoeffer found the proud, hypocritical Christians of his time to be repulsive and noted ironically that "heilige" people were often more worldly than the average man. The word "Welt" is used both in the Bible and by Bonhoeffer in both a positive and a negative sense. ${ }^{341}$ The negative sense is "the cravings of sinful man, the lust of his eyes and the boasting of what he has and does." ${ }^{342}$ In the positive sense, the world is "das ,Herz' ... der ganze Mensch, wie er vor Gott ist." 343 The positive version of "die Welt" and the Kingdom of God are synonyms. It is, in fact, the world for which Jesus died.

Bonhoeffer noted the "Diesseitigkeit" of Luther in his saying: "Sündige tapfer, aber glaube und freue dich in Christo um so tapferer!"344 In this command, Luther is claiming that a person should know that they cannot be perfect, and that neither their imperfection, nor the fact that they believe in Christ, should be concealed. Bonhoeffer said: "Wenn man völlig darauf verzichtet hat, aus sich selbst etwas zu machen - sei es einen Heiligen oder einen bekehrten Sünder .... dann wirft man sich Gott ganz in die Arme ... das ist Glaube ... und so wird man ein Mensch, ein

341 Bonhoeffer, Nachfolge, 92.

3421 John 2:16.

343 Bonhoeffer, Widerstand und Ergebung, 186.

344 Bonhoeffer, Nachfolge, 38. 
Christ." ${ }^{345}$ And so for Bonhoeffer, to become a Christian, one should stop trying to become anything: just be in God's presence and be yourself.

\subsection{The Kingdom of God is Religionless Christianity, which is Discipleship}

Augustine, Luther, Barth and Bonhoeffer each fought against idolatry in their society. Although idolatry appears different in every age, the weapons that these men used in their struggles were the same: the Bible, the truth, prayer, and faith. Augustine fought against Roman gods, Luther against the Pope and bishops, Barth against godless religion, and Bonhoeffer against Hitler and the German Christians. The conclusions that these men reached, circle around each other: the Kingdom of God consists of people who obey Christ. People who obey Christ do not believe in institutionalized religion, the Pope, the government, or the world. They believe in Christ alone. The people who make up the Kingdom of God can better serve religion, the Pope, the government and the world because they are not dependent on these things. Their willingness to help others is what turns them into the living stones out of which God's Kingdom is built.

The simultaneously worldly and other-worldly nature of God's Kingdom and of religionless Christianity comes not from a desire to fight for Christ, but to fight for one's neighbor. Bonhoeffer argued that, when Christians fight for Jesus, the church

345 Bonhoeffer, Widerstand und Ergebung, 196. 
turns into a religious community that, in truth, fights for its own concerns, and by doing so, shrinks its territory. If the church fights for the salvation of the world, then it remains open, and its territory will increase. ${ }^{346}$

Luther also noted that God's Kingdom consists of people, and therefore is both worldly and not worldly:

Die zum Reich Gottes Gehörenden, das sind alle, die als wahrhaft Glaubende in Christus und unter Christus sind. Denn Christus ist der König und Herr im Reiche Gottes, wie Psalm 2, 6 und die ganze Schrift sagt; deshalb ist er auch gekommen, um das Reich Gottes anzufangen und in der Welt aufzurichten. ${ }^{347}$

Luther follows his claim about God establishing his kingdom in the world with a quote from Jesus, who says: "My kingdom is not of the world, but whoever is of the truth hears my voice." 348 His kingdom is in the world, but not of the world, because it is eternal.

The following two contradictory statements from Bonhoeffer clearly express the nature of the Kingdom of God: "Jesus ruft nicht zu einer neuen Religion, sondern zum Leben,"349 but also: "Jeder Ruf Christi führt in den Tod." 350 It is only when one is free to die that he or she can truly live. Luther and Bonhoeffer were both prepared to die for their faith in Christ. This fact gave Bonhoeffer the courage to live completely in "Dasein-für-andere," or in a "diesseitig" state of mind, ${ }^{351}$ even when he was imprisoned and facing execution.

\footnotetext{
346 Wüstenberg, $A$ Theology of Life, 18.

347 Luther, Von weltlicher Obrigkeit, 9.

348 John 18:36.

349 Bonhoeffer, Widerstand und Ergebung, 194.

350 Bonhoeffer, Nachfolge, 81.

351 Bonhoeffer, Widerstand und Ergebung, 204, 196.
} 
Bonhoeffer was executed on April 9, 1945, four days after Hitler received proof of Bonhoeffer's collaboration in an assassination attempt aimed at him. Less than 24 hours before Bonhoeffer's death, he led a church service for his fellow prisoners. ${ }^{352}$ Payne Best, a British secret service agent who had been captured by the Germans, described the end of the impromptu prison church service:

(Bonhoeffer) had hardly finished his last prayer when the door opened and two evil-looking men in civilian clothes came in and said: "Prisoner Bonheoffer. Get ready to come with us." Those words "come with us"-for all prisoners they had come to mean one thing only-the scaffold.

We bade him good-bye-he drew me aside-“This is the end," he said. "For me the beginning of life." 353

Bonhoeffer's attitude shortly before and during his execution offers a concrete example of his faith. He had made the dual claim that the call of Jesus simultaneously leads to death and to life. Based on promises made by Christ, Bonhoeffer was confident that death was the beginning of life. However, this belief was, for Bonhoeffer, no excuse for living less fully here on the earth. Quite the opposite: "Ich fürchte, dass die Christen, die nur mit einem Bein auf Erde zu stehen wagen, auch nur mit einem Bein im Himmel stehen.“354 Bonhoeffer had invested himself whole-heartedly in the Kingdom of the World in an attempt to follow Christ—Nachfolge. In his death, Bonhoeffer continued to follow Christ, and was thus confident of his place in the Kingdom of God.

352 Metaxas, Bonhoeffer: Pastor, Martyr, Prophet, Spy, 528.

353 Ibid. 528.

354 Böttler, Paul Gerhardt in Kirche, Kultur und Lebensalltag, 78. 


\section{The Two Kingdoms Theory: A Visual Analysis}

Karl Barth has been credited as the first to coin the term "Two Kingdoms Theory" in regards to Luther's ideas presented in Secular Authority. ${ }^{355}$ This term, first used in 1922, can be misleading or problematic due to the many different concepts of what the "two kingdoms" might be. Gustaf Toernvall described the two kingdoms as "spiritual" and "worldly" regiments. Anders Nygren used the same terms as Toernvall, but also referred to the spheres as "spiritual" versus "temporal." 356 These terms can also be misleading. Luther differentiated between the two spheres based on God's decisions in regards to authority: there is a sphere in which God shares His authority (the Kingdom of the World) and a sphere in which God does not share His authority (the Kingdom of God). In this way, Luther's definition of both kingdoms can include elements of the spiritual, worldly, and temporal spheres. The other terms that are often associated with this theory are "church" and "state." Luther undoubtedly addressed the institutions of the church and the state in Von weltlicher Obrigkeit and they can be described as two kingdoms, but they are not synonymous with the Kingdom of God and the Kingdom of the World.

When one tries to distinguish God's Kingdom from the Kingdom of the World, the conversation often comes to the separation of church and state, even when it is understood that God's Kingdom and the earthly church are not synonymous. The

355 Lohse, Luthers Theologie in Ihrer Historischen Entwicklung und in Ihrem systematischen Zusammenhang, 172.

356 Lazareth, Christians in Society: Luther, the Bible, and Social Ethics, 15. 
various ideas that accompany the concept of the Two Kingdoms are difficult to explain. God's authority, human authority, spiritual, worldly, inner, outer, eternal, temporal, church, state, visible, invisible: what does the Two Kingdoms Theory mean? To what extent is it a political theory and to what extent is it spiritual? The following graphics are designed to help the reader understand the ideas of Luther, Bonhoeffer, and Barth in regards to these two spheres. ${ }^{357}$

I

Diagram 1: Two Spheres

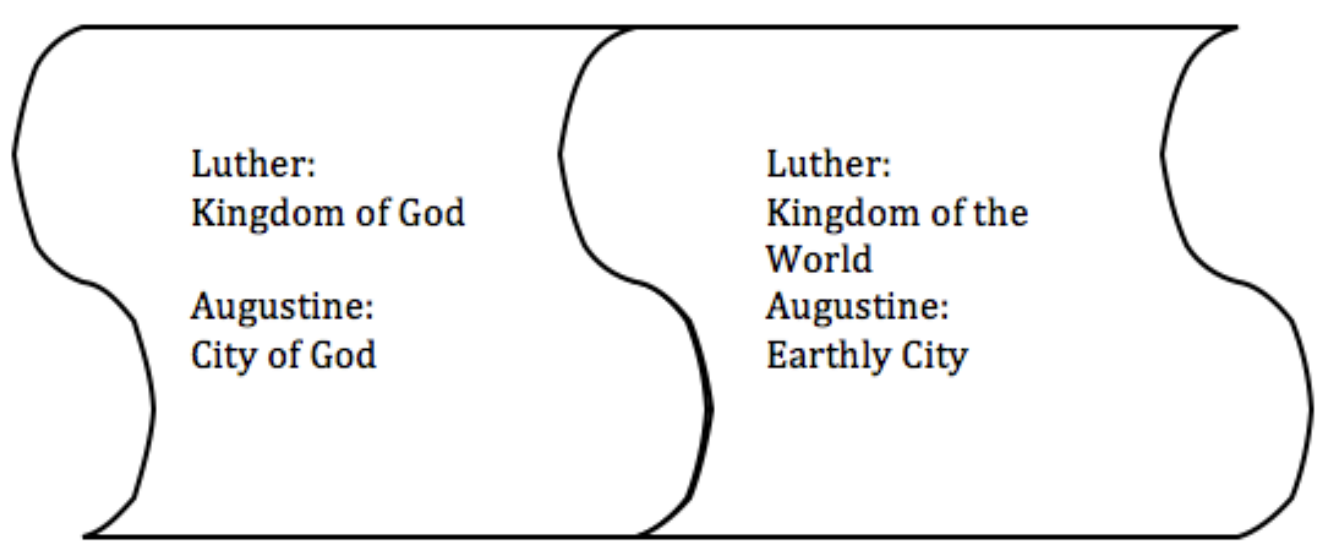

357 All graphics in this chapter are the original work of the author, Janet Gesme. Although the concepts displayed in the visual aids are based on descriptions found in the books of Augustine, Luther, Barth, and Bonhoeffer, the actual graphics are unique to this thesis. 
Diagram 2: God's Kingdom within the Kingdom of the World

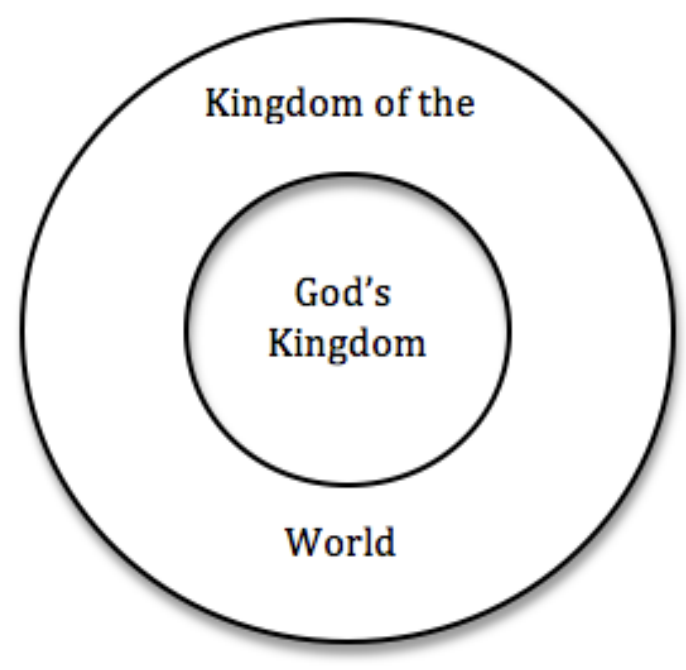

Diagram 3: The Kingdom of the World inside of God's Kingdom

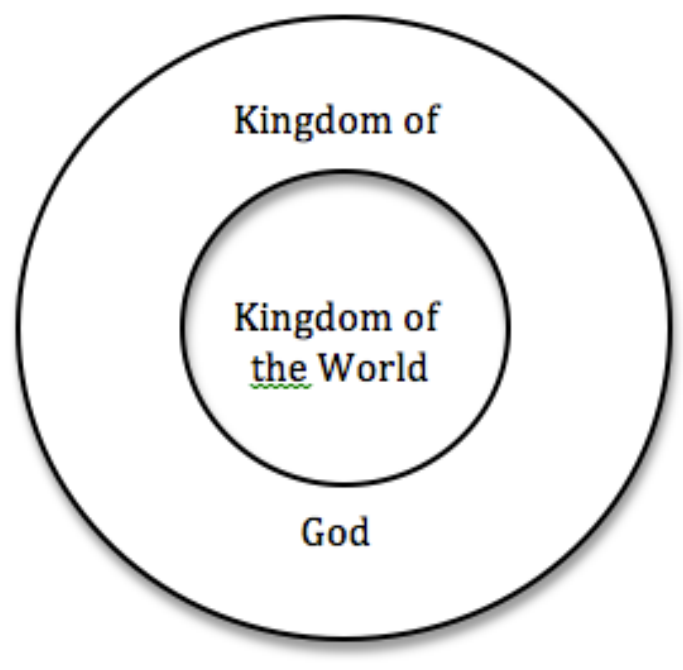




\section{Diagram 4: The Two Planes}

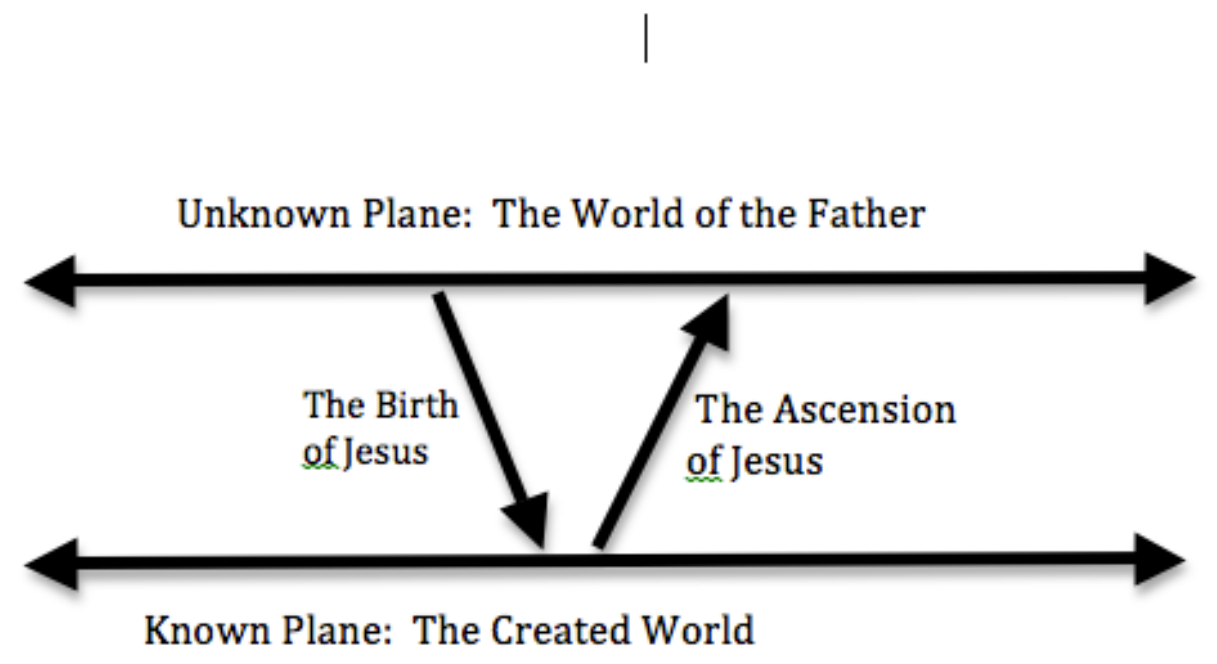

Diagram 5: The Tangent and the Circle

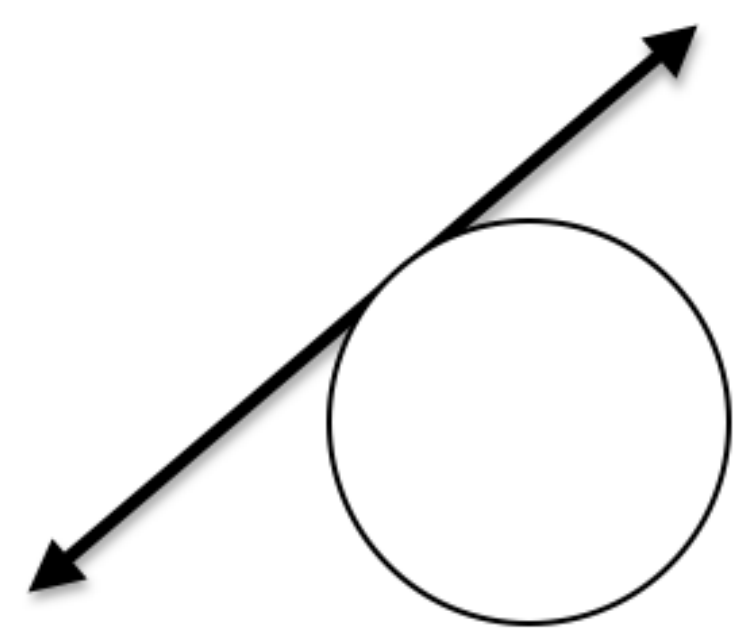


Diagram 6: The Separation that Connects

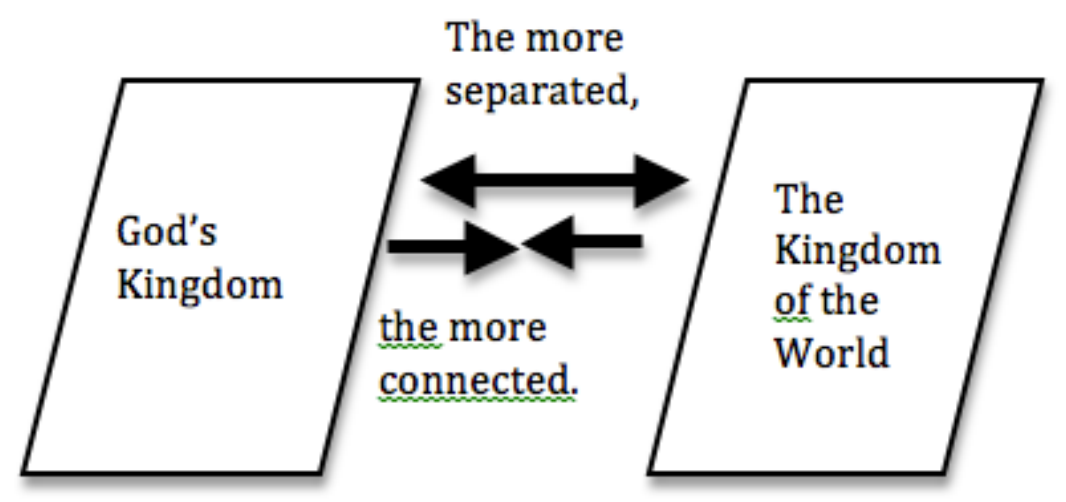

Diagram 7: The Boundaries of the Kingdom of God, the Church, and the State

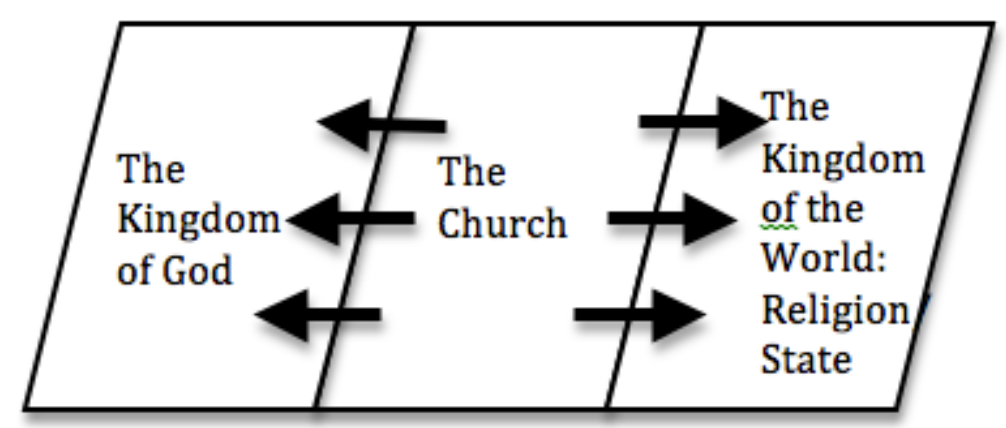


In the first diagram the two kingdoms are clearly delineated. In Luther's version, the Kingdom of God is the sphere in which God does not share his authority. No one can reach in and change that which has been decided by God. Augustine's definition of the two realms, like Luther's, clearly delineates the spheres, but in a different manner. For Augustine, everything good is a part of the City of God, and everything bad or evil is a part of the Earthly City. ${ }^{358}$

In Diagram 2, the Kingdom of the World represents everything that a person experiences in this lifetime. In Von Weltlicher Obrigkeit, Luther used the Bible to show that God's Kingdom can be found within this world because we are told to: "Seek first the Kingdom of God and His righteousness. ${ }^{\text {"359 }}$ Augustine also believed that the Kingdom of God can be found within this earthly existence. In his imagery, the building materials used to make the Kingdom of God come from the earth. It is a "house of living stones," built not by the church, but of the human beings that make up the church. ${ }^{360}$ It is the people who adhere to God who are themselves God's living temple. ${ }^{361}$

Whereas the second diagram depicts the observable universe from the human perspective, the third diagram shows the two kingdoms from God's perspective. Luther claimed that the Kingdom of the World had been established by God, ${ }^{362}$ and as his creation it remains under his control. According to Augustine,

\footnotetext{
358 Augustine, The City of God, Book XIV, Ch. 11. Book XVIII, Ch. 18.

359 Matthäus 6,33. Luther, Selections from his Writings, Secular Authority, 368.

360 Augustine, The City of God, Book VIII, Ch. 24.

${ }^{361}$ Ibid. Book XII, Ch. 9.

362 Luther, Selections from his Writings, Secular Authority, 366.
} 
faults and failures can only exist within the context of that which is good. ${ }^{363}$ That which is imperfect or incomplete can only be recognized as such if it can be compared to that which is perfect. Augustine, Luther, and Barth all believed that the power of the world has limits within God's power. Bonhoeffer believed that God's power posed a significant threat to Hitler and expressed this pending danger in his article, Der Führer und das Einzelne:

Es ist die furchtbare Gefahr der Gegenwart, dass wir über dem Schreien nach Autorität, des Führers oder des Amtes, vergessen, dass der Mensch einzelner ist vor der letzten Autorität und dass jeder, der sich hier am Menschen vergreift, ewige Gesetze verletzt, übermenschliche Verantwortung auf sich lädt, die ihn zuletzt erdrückt. 364

In Bonhoeffer's depiction, God's power to crush evil comes from his ultimate authority, which surrounds all of human existence.

The fourth diagram represents Barth's claim that God's Kingdom is unreachable and incomprehensible. ${ }^{365}$ Barth emphasized that people cannot find God's Kingdom using their own strength or volition: they must have God's help. Barth claimed that it is impossible for humans to reach the plane in which God exists-die unbekanntene Ebene, but that the life of Jesus created an intersection between the world of the Father and the earthly world-die bekanntene Ebene. ${ }^{366}$ In this example, Barth highlights Jesus' role as mediator between the two realms. God's Kingdom and his plan of salvation was clarified and completed through the life of Jesus. Luther's Von weltlicher Obrigkeit is in agreement with Barth's theory

\footnotetext{
363 Augustine, The City of God, Book XII, Ch. 3.

364 Bonhoeffer, Berlin 1932-1933, (German Version), 259.

365 Barth, The Epistle to the Romans, 29.

366 Barth, Römerbrief, 5.
} 
concerning our inability to reach God's level: "menschliche Ordnung (kann) sich ja nicht in den Himmel und über die Seele erstrecken."367

Barth and Luther emphasized the divide between God and man in different ways and in different contexts. For Barth, the concept was comprehensive: God is "wholly other" and exists on a different plane that is inaccessible to human beings. For Luther, the issue was contextual for his time: he insisted that humans, including the Pope and bishops, do not have authority over the soul. Luther argued that the human soul itself is, in part, unreachable. Luther's description of the soul and Barth's description of God are similar: they are simply beyond the understanding and control of humans.

Bonhoeffer expanded on Luther's idea by describing the soul as "der ganze Mensch." ${ }^{368}$ Bonhoeffer claimed that the heart, or soul, of a person is not the inner life, but the whole person in relation to God. ${ }^{369}$ It was Bonhoeffer's claim that God instigates and encourages the enlightenment and development of mankind. By forcing scientific, psychological, and technological advances on mankind, God gives the human race a better understanding of its position before him. Bonhoeffer claimed that "weltliche Interpretationen" are key to eliminating false understandings of God and clearing the way for a correct understanding for the God of the Bible. ${ }^{370}$

Bonhoeffer predicted the existence of a new language that would emerge in

367 Luther, Von weltlicher Obrigkeit, 29.

368 Bonhoeffer, Widerstand und Ergebung, 186

369 Bonhoeffer, Letters and Papers from Prison, 346.

370 Bonhoeffer, Widerstand und Ergebung, 193. 
the future to aid in weltliche Interpretationen: "Es wird eine neue Sprache sein, vielleicht ganz unreligiös, aber befreiend und erlösend, wie die Sprache Jesu, dass sich die Menschen über sie entsetzten und doch von ihrer Gewalt überwunden werden. “" ${ }^{371}$ In the years since Bonhoeffer's death, a powerful new language has emerged; one that is decidedly non-religious, liberating to some and shocking to others. It has, without question, become a dominant and common language for much of the population of the planet. This universal dialect is computer-based technology. With the use of computer technology, mankind has experienced the ability to access and transfer information as never before. Entire libraries worth of information can now be stored in a space that is the size of a single volume.

It is possible to load several full-length feature films on a piece of equipment the size of a human thumb, transport them to a different place and view them with a different piece of equipment. Or, more incredibly, one can transmit this same information wirelessly, through the air. No doubt mankind is nowhere near the limit of what is possible in this realm. If it is feasible for mere humans to achieve such heights of information compression and transmission, consider what must be possible for God. Regardless of how much physical space the soul occupies, if indeed it takes up any space at all in terms of human understanding, it does not seem unreasonable to expect that God, and only God, can easily access, alter, and transport a soul wherever he chooses.

God's ability to transfer the soul, or the whole person, from one body to

371 Bonhoeffer, Widerstand und Ergebung, 157. 
another, is easier to understand in light of today's technology. ${ }^{372}$ Luther referred to this transfer as "(die Seele) gen Himmel oder zur Hölle führen."373 Although the transfer of the soul is now easier to imagine, the unknown, unreachable plane remains inaccessible to humans. As Luther argued long ago, humans cannot access either the human soul, in terms of its transfer to a new body, nor can they access the "Welt des Vaters." 374 Barth's depiction of the unbekanntene Ebene and the bekanntene Ebene correspond to and expand upon Luther's Two Kingdoms Theory. Not only do humans not have authority over the soul or God's kingdom, but, according to Barth, they cannot even access it without God's revelation in Jesus Christ.

The fifth diagram represents another geometrical concept presented by Barth in Römerbrief: “(Die neue Welt des Heiligen Geistes) berührt (die alte Welt des Fleisches) wie die Tangente einen Kreis, ohne sie zu berühren, und gerade indem sie sie nicht berührt, berührt sie sie als ihre Begrenzung, als neue Welt." ${ }^{375}$ With this description of the two spheres, Barth described Jesus Christ as the ultimate paradox, belonging to both the Kingdom of the World and the Kingdom of God: Jesus as primal history and the end of history. Although Christ was an historical figure, Barth argues that Jesus is "historisch nicht zu bestimmen" because

\footnotetext{
372 See Appendix G.

${ }^{373}$ Luther, Von weltlicher Obrigkeit, 26.

374 Ibid. 29-30: „Nun kann menschliceh Ordnung sich ja nicht in den Himmel und über die Selle erstrecken, sondern nur auf Erden ... Psalm 115, 16 sagt: ,Der Himmel ist der Himmel des Herrn, aber die Erde hat er den Menschenkindern gegeben'. Das heißt: was auf Erden ist und zum zeitlichen, irdischen Reich gehört, da hat ein Mensch wohl Gewalt von Gott; aber was zum Himmel und zum ewigen Reich gehört das ist allein unter dem himmlischen Herrn“. Barth, Römerbrief, 6.

375 Barth, Römerbrief, 6.
} 
God raised him from the dead. ${ }^{376}$ It is Christ who touches mankind without bending himself to the world through sin. It is through this contact without compromise that Barth understands Jesus' ability to offer salvation to the world.

Bonhoeffer's writings agree with and expand upon Barth's concept. He described Jesus as the both the limit and the center of our existence:

Wo steht (Christus)? Für mich, an meiner Stelle, wo ich stehen sollte. Er steht dort, weil ich da nicht stehen kann, d. h. er steht an der Grenze meiner Existenz und doch an meiner Stelle. Das ist ein Ausdruck für die Tatsache, dass ich durch einen von mir unüberschreitbare Grenze von dem Ich, das ich sein soll, getrennt bin. .. Darauf kommt es an, dass der Mensch, indem er seine Grenze in Christus erkennt, in dieser Grenze zugleich seine neue Mitte wiedergefunden sieht. ${ }^{377}$

Bonhoeffer claims that Christ exists for humans in both extremes: in the center of life, and at the limit of human existence. Bonhoeffer believed that Jesus stands where the individual should, but cannot stand: taking all that is evil and all that is good in humanity to its ultimate goal. On the cross, Christ stood in for the evil side of human nature, taking the punishment for mankind. Before God and in everyday life, Christ fulfills the perfection for which mankind strives, but cannot attain. In Bonhoeffer's opinion, Jesus had the ability and the desire to fulfill all that was lacking in each individual's life.

The sixth diagram continues the exploring the paradoxical nature of God and his kingdom. Luther described the people with the least need for the law as those who support it the most. ${ }^{378}$ It is the people who do not break the law, for whom no

\footnotetext{
376 Barth, Römerbrief, 6.

377 Bonhoeffer, Berlin: 1932-1933, (German Version) 306-307.

378 Luther, Selections from his Writings, Secular Authority, 372.
} 
law is necessary, who are the most willing to help prevent crime by upholding the law. The more one's behavior merits the need for the law, the less the person wants to have it, and vice-versa, the less one's behavior merits the need for the law, the more they want the laws enacted. It is the independence from the state that makes an authentic Christian willing and able to support the state.

Barth noted that the Kingdom of God has the effect of making one aware that Heimat is not to be found on earth: neither in the church as an organization nor in the government. ${ }^{379}$ According to Barth, an understanding of "das neue Äon," or of heaven, makes it impossible for one to deify the state. ${ }^{380}$ It is also impossible to attach undue significance to earthly religions, because in heaven there is no place for religion as such. This, Barth believed, is symbolized by the lack a temple in the coming age: "In dieser Stadt wird bezeichnenderweise der Tempel fehlen: ,Denn der Herr, der allmächtige Gott, ist ihr Tempel und das Lamm."'381 Whereas Luther merely made the claim that there is no need of law in the Kingdom of God, Barth in Rechtfertigung and Recht and Bonhoeffer in Nachfolge went one step further, claiming that neither religion nor law is needed in God's kingdom.

After Barth separated the Christian's hope from earthly things and organizations, he draws the conclusion that, because the church recognizes itself to be a part of the Kingdom of Heaven, it will be more involved in worldly matters. It is

379 Barth, Church and State, 45.

380 Ibid. 42.

381 Barth, Rechtfertigung und Recht, 22. 
a Biblical command that the church pray for the state. ${ }^{382}$ The church, according to Barth, will be convinced, through prayer, to do the "entsprechende Arbeit" in order to improve worldly organizations. ${ }^{383}$ Similarly, Bonhoeffer believed that an exclusive attachment to the person of Jesus Christ plunges the Christian into a "diesseitige" existence, in which one lives in complete service to others-das Fürandere-dasein. ${ }^{384}$

The last diagram depicts Bonhoeffer's explanation of the relationship of the church to both the Kingdom of God and the Kingdom of the World. The church in this graphic is not a worldly organization, but all people who are "friends of God." Churches in the organizational sense are represented as religion. Bonhoeffer believed that the church should not draw boundaries between itself and the world. It must offer an open invitation to all people at all times. "Where the church establishes its boundaries itself, legalistically and beforehand, (it) betrays its commission to call men to salvation." 385 There will, however, be boundaries anywhere the invitation to fellowship with God is rejected either by members of the secular society or religious people. Bonhoeffer argues that these boundaries must be confirmed and noted by the church, and yet "the true church ... can never want to determine of itself the position of those who do not belong to it. Its claim to be the church is never meant to imply that now the separation of the just from the

\footnotetext{
382 1. Timothy 2:1-2: "I urge, then first of all, that requests, prayers, intercession and thanksgiving be made for everyone - for kings and all those in authority, that we may live peaceful and quiet lives in all godliness and holiness."

383 Barth, Rechtfertigung und Recht, 43.

384 Bonhoeffer, Widerstand und Ergebung, 204.

385 Quote from English source. Bonhoeffer, The Way to Freedom, 83.
} 
unjust is to take place." ${ }^{386}$ According to Bonhoeffer, the church should not force itself on anyone, but it should keep the door open as an invitation to all who wish to know God.

386 Quote from English source. Bonhoeffer, The Way to Freedom, 78-79. 


\section{Conclusion}

Augustine, Luther, Barth, and Bonhoeffer had a common goal to distinguish between the Creator and His creation. In the abstract, this goal is not difficult to attain, but in reality it is quite complicated. God made His creation creative, which makes it difficult to differentiate between the will of God and the will of mankind. A person's ability to think and act independently from God introduces the possibility of acting outside of or against His will. Within the scheme of free will, making decisions is not only a privilege, but a necessity of being human. Difficulties arise because individuals do not always agree as to what is good and what is bad, what is creative and what is destructive, or what lies inside and what lies outside the will of God. The Two Kingdoms Theory is difficult to understand not only due to the human tendency to disagree concerning the will of God, but also because it is often difficult to know to which two spheres one is referring when the "two kingdoms" are mentioned.

For Augustine, the Two Kingdoms consisted of that which is good and that which is bad. For Luther, they were the place in which God shares His authority and the place in which He alone has authority. For Barth, they are either heaven and earth or church and state, but the differentiation between the spheres was less important to him than the active engagement of the believer in the world. For Bonhoeffer, the spheres were "die letzten und die vorletzten Dinge." 387 Bonhoeffer's concept of ultimate and penultimate refers in part to what is permanent and what is

387 Bonhoeffer, Ethik, 137. 
temporary and associated God's will with that which is eternal. He separated the spheres into two different realities and posed the ultimate question to Christians:

die letzte Entscheidungsfrage (für den Christen ist) ... mit welcher Wirklichkeit wir in unserem Leben rechnen wollen, mit der Wirklichkeit des Offenbarungswortes Gottes oder mit den sogenannten Realitäten des Lebens, mit der göttlichen Gnade oder mit den irdischen Unvollkommenheiten, mit der Auferstehung oder mit dem Tod. 388

Both Luther and Bonhoeffer took part in the fight against the deification of things and humans in their time. It is the duty of Christians today to continue this fight. Although few Christians have the intention of idolizing people, things, or organizations, the desire to control life, the creation and ultimately, the desire to control God, leads them to various forms of idolatry. The Christian wants to hold God in his hand, but that is impossible. It is God who holds us in his hand. Bonhoeffer believed that he, as well as Luther, had been grasped by God. ${ }^{389}$ The result of being grasped by God is discipleship: to take part in God's Kingdom both on earth and in heaven. The result of an attempt to grasp God in order to control Him is idolatry: the rejection of the living, all-powerful God in favor of a pale, disappointing substitute.

All things, people, and organizations have the potential to be positive or negative. Because of this positive potential, Barth encouraged Christians to pray for government officials and church leaders, and to do the corresponding work in the

\footnotetext{
388 Bonhoeffer, Ethik, 33.

389 Bonhoeffer, The Cost of Discipleship, 47; Metaxas, Bonhoeffer: Pastor, Martyr, Prophet, Spy, 209.
} 
world. ${ }^{390}$ What is the corresponding work for us today? What is God's will? How does one distinguish between the living God and our false imaginations concerning God? How can Christians live simultaneously in God's Kingdom and in the Kingdom of the World? Bonhoeffer believed that these questions must be answered anew everyday and in every age:

Der Wille Gottes kann sehr tief verborgen liegen unter vielen sich anbietenden Möglichkeiten. Weil er auch kein von vornherein festliegendes System von Regeln ist, sondern in den verschiedenen Lebenslagen ein jeweils neuer und verschiedener ist, darum muss immer wieder geprüft werden, was der Wille Gottes sei. Herz, Verstand, Beobachtung, Erfahrung müssen bei dieser Prüfung miteinanderwirken. ${ }^{391}$

The Kingdom of God is God's will in action. It is dynamic and ever changing, requiring each person to be fully invested in life. Luther's Two Kingdoms Theory and Bonhoeffer's Religionless Christianity distinguish God from mankind and, in doing so, they push the Christian into God's presence, where the adventure of life truly begins.

390 Barth, Church and State, 48, 79.

391 Bonhoeffer, Ethik, 323-324. 


\section{Bibliography}

Anz, Wilhelm, Wolter, Michael, and Wildemann, Bernd. Existenz und Sein: Karl Barth und die Marburger Theologie. Tübingen: J.C.B. Mohr (Paul Siebeck), 1989.

Augustine. The City of God. Translated by Henry Bettenson. New York: Penguin Books, 1980.

Bailey, Kenneth E. Poet \& Peasant and Through Peasant Eyes. Grand Rapids: William B. Eerdmans Publishing Company, 1976.

Bainton, Roland H. The Reformation of the Sixteenth Century. Boston: Beacon Press, 1966.

Barth, Karl. Church and State. Translated by G. Ronald Howe. London: Student Christian Movement Press, 1939.

Barth, Karl. The Epistle to the Romans. New York: Oxford University Press, 1965.

Barth, Karl und Godsey, John D. How I Changed my Mind. Richmond: John Knox Press, 1966.

Barth, Karl. Rechtfertigung und Recht. Zürich: Evangelischer Verlag A. G. Zollikon, 1944.

Bonhoeffer, Dietrich. Berlin: 1932-1933. Minneapolis: Augsburg Fortress, 2009.

Bonhoeffer, Dietrich. Berlin 1932-1933. Gütersloh: Chr. Kaiser/Gütersloher Verlagshaus, 1997.

Bonhoeffer, Dietrich. The Cost of Discipleship. New York: Touchstone, 1995.

Bonhoeffer, Dietrich. Ethics. New York: First Touchstone Edition, 1995.

Bonhoeffer, Dietrich. Ethik. Gütersloh: Gütersloher Verlagshaus, 1992.

Bonhoeffer, Dietrich. Letters and Papers from Prison. New York: Mcmillan Publishing Co., 1971.

Bonhoeffer, Dietrich. The Way To Freedom: Letters, Lectures and Notes, 1935-1939. London: William Collins, Sons and Co. Ltd., 1966.

Bonhoeffer, Dietrich. Widerstand und Ergebung: Briefe und Aufzeichnungen aus der Haft. Gütersloh: Gütersloher Verlagshaus GmbH., 1951. 
Böttler, Winfried. Paul Gerhardt in Kirche, Kultur und Lebensalltag. Berlin: Frank \& Timme GmbH Verlag, 2007.

Franke, Walter. Lehrbuch für den evangelischen Religionsunterricht an höheren Schulen, Mittelstufe: Zweiter Teil: Helden und Werke der Kirche. Frankfurt am Main: Verlag Moritz Diesterweg, 1937.

Glenthoj, Jorgen; Heiene, Gunnar; Murtorinne, Eino; Nicolaisen, Carsten; Oftestad, Bernt Torvild. Die Öffentliche Verantwortung der Evangelisch-lutherischen Kirche in einer Bedenntnissituation: das Paradigma des norwegischen Kirchenkampfes. Erlangen: Martin-Luther-Verlag, 1984.

Green, Clifford J. Bonhoeffer: A Theology of Sociality. Grand Rapids: Wm. B. Eerdmans Publishing Co., 1999.

Hakim, Albert B. Historical Introduction to Philosophy. New York: Macmillan Publishing Co., 1987.

Hamburger, Philip. Separation of Church and State. Harvard: Harvard University Press. 2004.

Heldberg, Thomas. Martin Luther - Vater der Reformation, Vordenker der Trennung von Staat und Kirche. Norderstedt: Grin Verlag, 2005.

Hoffmann, Peter. Editor. Behind Valkyrie: German Resistance to Hitler: Documents. Quebec: McGill-Queen's University Press, 2011.

The Holy Bible. New International Version. Grand Rapids: Zondervan Publishing House, 1984.

Jodock, Darrell. "Lutherans and Politics." The Lutheran. October 2012: 20-25.

Kant, Immanuel. The Fundamental Priciples of the Metaphysic of Ethics. Translated by Otto Manthey-Zorn. New York: D. Appleton-Century Company, 1938.

Karant-Nunn, Susan. Reformation of Ritual: An Interpretation of early modern Germany. New York: Routledge, 1997.

Lazareth, William H. Christians in Society: Luther, the Bible, and Social Ethics. Minneapolis: Augsburg Fortress, 2001.

Lohse, Bernhard. Luthers Theologie in Ihrer Historischen Entwicklung und in Ihrem systematischen Zusammenhang. Göttingen: Vandenhoeck und Ruprecht, 1995. 
Luther, Martin, Übersetzer. Die Bibel: Revidierte Fassung von 1984. Stuttgart: Deutsche Bibel Gesellschaft. 1999.

Luther, Martin. Luther's Works, Volume 36: Word and Sacrament II. Edited by Abdel Ross Wentz and Helmut T. Lehmann. Philadelphia: Muhlenberg Press, 1959.

Luther, Martin. On the Jews and Their Lies. Translated by Martin H. Bertram. Edited by Coleman Rydie. Kindle Version. 2008.

Luther, Martin. Selections from His Writings. Edited by John Dillenberger. New York: Doubleday, 1961.

Luther, Martin. Von weltlicher Obrigkeit, wie weit man ihr gehorsam schuldig sei. Hamburg: tredition $\mathrm{GmbH}, 1523$.

Luther, Martin. Von den Juden und ihren Lügen. Jürgen Rahf presents great Books of History, Vol. I. http://archive.org/details/VonDenJudenUndIhrenLgen. Located: 07/07/2013.

Mantey, Volker. Zwei Schwerter Zwei Reiche. Tübingen: Mohr Siebeck, 2005.

MacDonald, Alan R. "Ecclesiastical Representation in Parliament in PostReformation Scotland: The Two Kingdoms Theory in Practice." The Journal of Ecclesiastical History, 50, no. 1 (1999): 38-61.

Metaxas, Eric. Bonhoeffer: Pastor, Martyr, Prophet, Spy. Nashville: Thomas Nelson, Inc., 2010.

Monyai, Mokgwasi Kaizer. “The significance of Luther's two kingdoms theory to the South African situation." Diss., Lutheran Theological Seminary at Gettysburg, 1992.

Neuss, Erdmann. "Luthers Stellungnahme zu den Kriegsfällen seiner Zeit." Diss., Halle, Univ. Theol. Fak., 1971.

Nicolaisen, Carsten und Siegele-Wenschkewitz, Leonore. Theologische Fakultäten im Nationalsozialismus. Göttingen: Vandenhoeck und Ruprechet, 1993.

O’Donnell, James J. Augustine: A New Biography. New York: Harper Perennial, 2005.

Offerman, Doris. Schleiermachers Einleitung in die Glaubenslehre. Berlin: Verlag Walter de Gruyter GmbH \& Co., 1969.

Sahakian, William S. Philosophies of Life. New York: Philosophical Library, Inc., 1963. 
Schleiermacher, Friedrich. Kritische Gesamtausgabe: Schriften und Entwürfe, Band 13: Der christliche Glaube, 2. Auflage (1830-1831), Teilband 1. Berlin: Walter de Gruyter GmbH \& Co., 2003.

Spitz, Lewis W. The Protestant Reformation. Englewood Cliffs: Prentice-Hall, 1966.

Spitz, Lewis W. The Protestant Reformation: 1517-1559. New York: Harper and Row, Publishers, 1985.

Thompson, W. D. J Cargill. The Political Thought of Martin Luther. Totowa, New Jersy: The Harvester Press, 1984.

Vargas, Alicia. "Mujerismo and The Two Kin-doms: Distinction and Reconciliation." Dialog: A Journal of Theology, Vol. 49, Issue 3 (2010): 231-237.

Whitford, David M. "Cura Religionis or Two Kingdoms: The Late Luther on Religion and the State in the Lectures on Genesis." Church History Vol. 75 Issue 1 (2004): 4162.

Wüstenberg, Ralf K. A Theology of Life: Dietrich Bonhoeffer's Religionless Christianity. Grand Rapids: Wm. B. Eerdmans Publishing Co., 1998. 


\section{Appendix A: The Power of God}

Job 12: 13-21:

To God belong wisdom and power; counsel and understanding are his. What he tears down cannot be rebuilt; the man he imprisons cannot be released. If he holds back the waters, there is drought; if he lets them loose, they devastate the land. To him belong strength and victory; both deceived and deceiver are his. He leads counselors away stripped and makes fools of judges. He takes off the shackles put on by kings and ties a loincloth around their waist. He leads priests away stripped and overthrows men long established. He silences the lips of trusted advisers and takes away the discernment of elders. He pours contempt on nobles and disarms the mighty.

Jeremiah 27: 5:

With my great power and outstretched arm I made the earth and its people and the animals that are on it, and I give it to anyone I please.

John 19: 7-11a:

The Jews insisted, "We have a law, and according to that law he must die, because he claimed to be the Son of God." When Pilate heard this, he was even more afraid, and he went back inside the palace. "Where do you come from?" he asked Jesus, but Jesus gave him no answer. "Do you refuse to speak to me?" Pilate said. "Don't you realize I have power either to free you or to crucify you?" Jesus answered, "You would have no power over me if it were not given to you from above." 


\section{Appendix B: The Worth of a Counselor}

A person's social standing should not affect how a leader receives their advice. There is no one above suspicion, nor should anyone be ignored due to being seemingly unimportant. Luther based these views on the following verses:

Numbers 22:21-33:

Balaam got up in the morning, saddled his donkey and went with the princes of Moab. But God was very angry when he went, and the angel of the Lord stood in the road to oppose him. Balaam was riding on his donkey, and his two servants were with him. When the donkey saw the angel of the Lord standing in the road with a drawn sword in his hand, she turned off the road into a field. Balaam beat her to get her back on the road.

Then the angel of the Lord stood in a narrow path between two vineyards, with walls on both sides. When the donkey saw the angel of the Lord, she pressed close to the wall, crushing Balaam's foot against it. So he beat her again.

Then the angel of the Lord moved on ahead and stood in a narrow place where there was no room to turn, either to the right or to the left. When the donkey saw the angel of the Lord, she lay down under Balaam, and he was angry and beat her with his staff. Then the Lord opened the donkey's mouth, and she said to Balaam, "What have I done to you to make you beat me these three times?

Balaam answered the donkey, "You have made a fool of me! If I had a sword in my hand, I would kill you right now."

The donkey said to Balaam, "Am I not your own donkey, which you have always ridden, to this day? Have I been in the habit of doing this to you?

"No," he said.

Then the Lord opened Balaam's eyes, and he saw the angel of the Lord standing in the road with his sword drawn. So he bowed low and fell facedown. The angel of the Lord asked him, "Why have you beaten your donkey these three times? I have come here to oppose you because your path is a reckless one before me. The donkey saw me and turned away from me these three times. If she had not turned away, I would certainly have killed you by now, but I would have spared her."

Isaiah 14:12-15:

How you have fallen from heaven, 0 morning star, son of the dawn! You have been cast down to the earth, you who once laid low the nations! You said in your heart, "I will ascend to heaven; I will raise my throne above the stars of God; I will sit enthroned on the mount of assembly, on the utmost heights of the sacred mountain. I will ascend above the tops of the clouds; I will make myself like the Most High." But you are brought down to the grave, to the depth of the pit. 
Appendix C: The Primary Bible Verses Used by Luther in Von weltlicher Obrigkeit

Romans 13: 1-3:

Every one must submit himself to the governing authorities, for there is no authority except that which God has established. The authorities that exist have been established by God. Consequently, he who rebels against the authority is rebelling against what God has instituted, and those who do so will bring judgment on themselves. For rulers hold no terror for those who do right, but for those who do wrong. Do you want to be free from fear of the one in authority? Then do what is right and he will commend you.

First Peter 2: 13-14:

Submit yourselves for the Lord's sake to every authority instituted among men: whether to the king, as the supreme authority, or to governors, who are sent by him to punish those who do wrong and to commend those who do right.

Matthew 5: 39:

But I tell you, do not resist an evil person. If someone strikes you on the right cheek, turn to him the other also. 


\section{Appendix D: Exceptions to the Rule}

The third section of Secular Authority refers almost exclusively to the Old Testament in order to advise rulers in how to govern their people. These verses from the New Testament are the exceptions:

Luke 22: 25:

Jesus said to them, "The kings of the gentiles lord it over them and those who exercise authority over them call themselves benefactors."

John 3: 20-21:

Every one who does evil hates the light, and will not come into the light for fear that his deeds will be exposed. But whoever lives by the truth comes into the light, so that it may be seen plainly that what he has done has been done through God.

Acts 5: 29:

Peter and the other apostles replied, "We must obey God rather than man!" 


\section{Appendix E: The Command of the Old Testament to Love your Enemy}

Exodus 23: 4-5:

If you come across your enemy's ox or donkey wandering off, be sure to take it back to him. If you see the donkey of someone who hates you fallen down under its load, do not leave it there; be sure you help him with it.

Proverbs 25: 21-22:

If your enemy is hungry, give him food to eat; if he is thirsty, give him water to drink. In doing this, you will heap coals on his head, and the Lord will reward you.

2 Kings 6: 21-23:

When the king of Israel saw them, he asked Elisha, "Shall I kill them, my father? Shall I kill them?" "Do not kill them," he answered. "Would you kill men you have captured with your own sword or bow? Set food and water before them so that they may eat and drink and then go back to their master." So he prepared a great feast for them, and after they had finished eating and drinking, he sent them away, and they returned to their master. So the bands from Aram stopped raiding Israel's territory. 


\section{Appendix F: The Sermon on the Mount}

Matthew 5: 3-12:

Blessed are the poor in spirit, for theirs is the kingdom of heaven.

Blessed are those who mourn, for they will be comforted.

Blessed are the meek, for they will inherit the earth.

Blessed are those who hunger and thirst for righteousness, for they will be filled.

Blessed are the merciful, for they will be shown mercy.

Blessed are the pure in heart, for they will see God.

Blessed are the peacemakers, for they will be called sons of God.

Blessed are those who are persecuted because of righteousness, for theirs is the kingdom of heaven.

Blessed are you when people insult you, persecute you and falsely say all kinds of evil against you because of me. Rejoice and be glad, because great is your reward in heaven, for in the same way they persecuted the prophets who were before you. 


\section{Appendix G: The Transfer of the Soul}

\section{Corinthians 15:51-54:}

Listen, I tell you a mystery: We will not all sleep, but we will all be changed - in a flash, in the twinkling of an eye, at the last trumpet. For the trumpet will sound, the dead will be raised imperishable, and we will be changed. For the perishable must clothe itself with the imperishable, and the mortal with immortality. When the perishable has been clothed with the imperishable, and the mortal with immortality, then the saying that is written will come true: "Death has been swallowed up in victory."

\section{Corinthians 5:1-4:}

Now we know that if the earthly tent we live in is destroyed, we have a building from God, an eternal house in heaven, not built by human hands. Meanwhile we groan, longing to be clothed with our heavenly dwelling, because when we are clothed, we will not be found naked. For while we are in this tent, we groan and are burdened, because we do not wish to be unclothed but to by clothed with our heavenly dwelling, so that what is mortal may be swallowed up by life.

\section{John 14:1-3:}

Do not let your hearts be troubled. Trust in God, trust also in me. In my Father's house are many rooms; if it were not so, I would have told you. I am going there to prepare a place for you. And if I go and prepare a place for you, I will come back and take you to be with me that you also may be where I am. 